WATER-RESOURCES ACTIVITIES OF THE

U.S. GEOLOGICAL SURVEY IN WYOMING,

OCTOBER 1989 THROUGH SEPTEMBER 1991

Compiled by K.E. Wilson

U.S. GEOLOGICAL SURVEY

Open-File Report 91-226

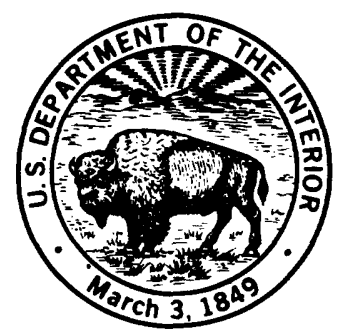

Cheyenne, Wyoming 1991 


\section{U.S. DEPARTMENT OF THE INTERIOR \\ MANUEL LUJAN, JR., Secretary \\ U.S. GEOLOGICAL SURVEY \\ Dallas L. Peck, Director}

\section{FUNDING AGENCIES}

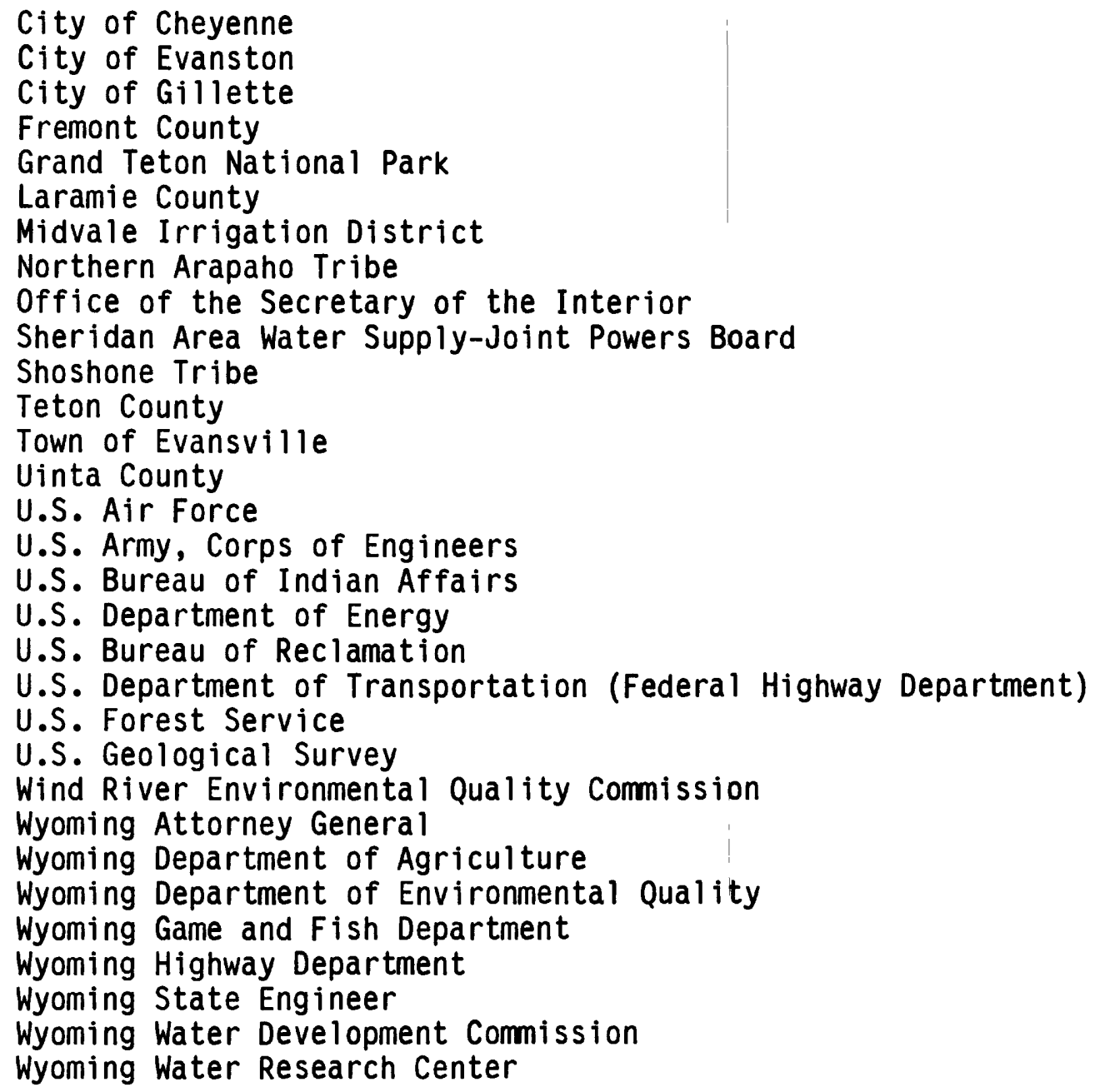

For additional information write to:

\section{District Chief}

U.S. Geological Survey

2617 E. Lincolnway, Suite B

Cheyenne, Wyoming 82001
Copies of this report can be purchased from:

U.S. Geological Survey

Books and Open-File Reports Section Box 25425, Federal Center Denver, Colorado 80225 
Abstract............................................. 1

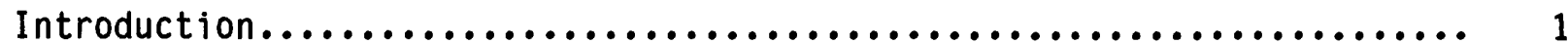

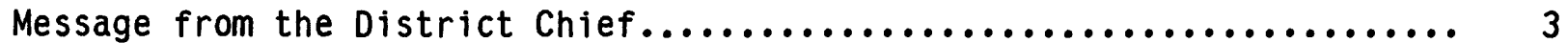

Origin of the U.S. Geological Survey........................... 5

Mission of the Water Resources Division....................... 6

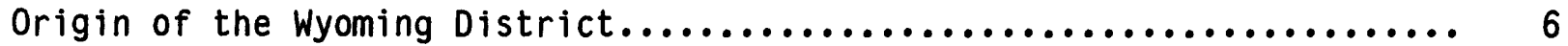

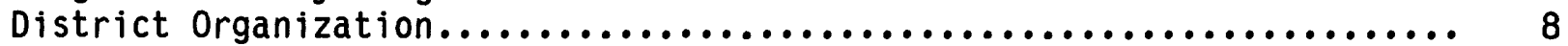

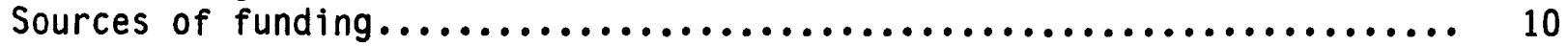

Summary of hydrologic conditions during water year $1990 \ldots \ldots \ldots \ldots \ldots \ldots \ldots 11$

Precipitation ....................................... 11

Streamf 10 ........................................... 12

Floods............................................. 12

Chemical quality of surface water........................ 12

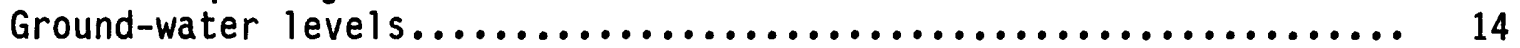

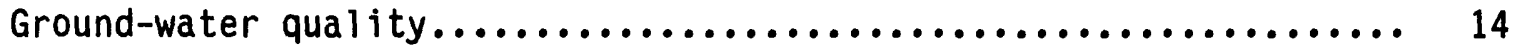

Wyoming water issues....................................... 14

Surface-water issues.................................. 17

Surface-water-quality issues ............................ 17

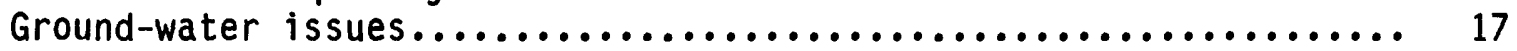

Ground-water-quality issues............................ 18

Data-collection sites...................................... 19

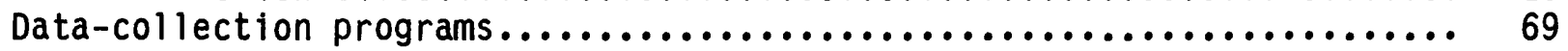

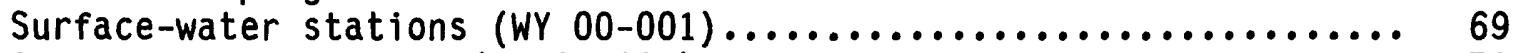

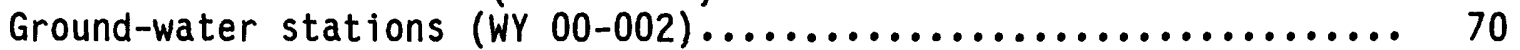

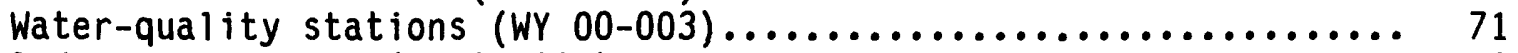

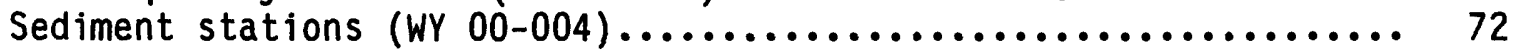

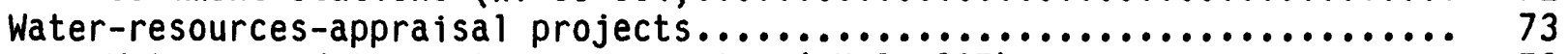

Water-use data system for Wyoming (WY 84-007) ................ 73

Site characterization and preparation of a remedial-action plan

for the Installation Restoration Program at F.E. Warren Air

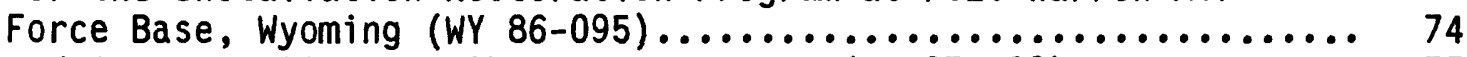

Flood investigation for Cheyenne, Wyoming (WY 87-100).......... 75

Streamflow and channel characteristics of the Bear River at

Evanston, Wyoming (WY $88-105) \ldots \ldots \ldots \ldots \ldots \ldots \ldots \ldots \ldots \ldots$

Field screening study of water quality, bottom sediments, and biota of the Riverton Irrigation Project, Fremont County,

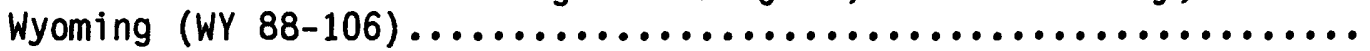

Description and analysis of water-level changes in the High

Plains Aquifer, Wyoming (WY 88-107)......................

Detailed study and assessment of irrigation drainage in the

Kendrick Reclamation Project area, Wyoming (WY 88-111).........

Quality of surface water and ground water in the Owl Creek

basin, Wind River Indian Reservation, Wyoming (WY 88-114).......

Hydrologic appraisal of the Wind River Indian Reservation,

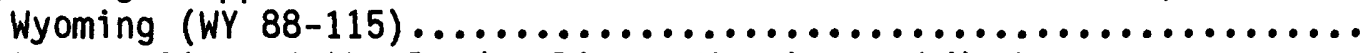

Water quality of the Powder River, Wyoming and Montana

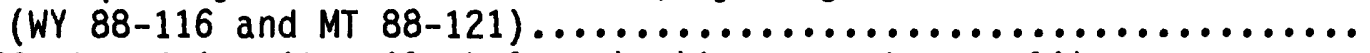

Effects of in-situ oil-shale retorting on water quality near

Rock Springs, Wyoming (WY $88-118$ )....................... Water resources of Hot Springs County, Wyoming (WY $89-119$ )........ 


\section{CONTENTS--Cont inued}

Page

Determination of long-term atmospheric deposition quality and climatic changes in the Western United States using continuous ice cores, Wind River Range, Wyoming (WY 90-120)......

Quantification of seepage and sedimentation in selected irrigation canals on the Wind River Indian Reservation,

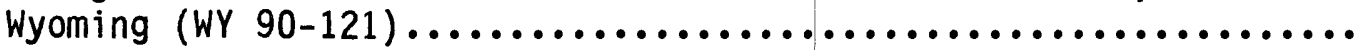

Hydrologic characteristics in fractured-rock aquifer, Rock

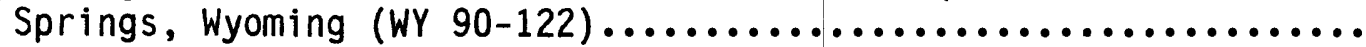

Assessment of the current collection of basic records sediment data base (WY 90-123).

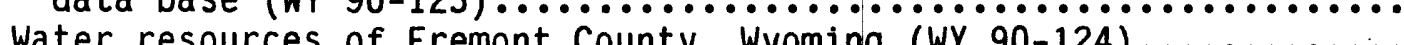

Preparation of U.S. Department of the Interior environmental impact statement on operation of Glen Canyon Dam, Arizona

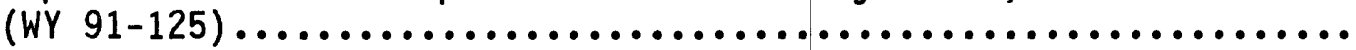

Characterization of water resources in Teton County, Wyoming

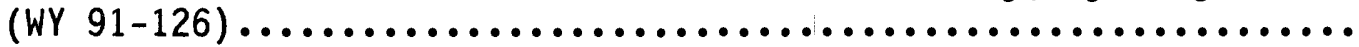

Evaluation of potential causes of water-quality changes in major

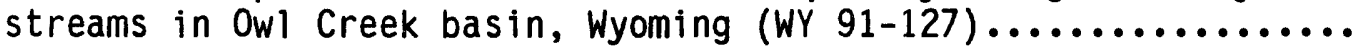

Estimates of monthly streamflow characteristics for ungaged sites, Wind River Indian Reservation, Wyoming (WY 91-128).............

Summary and evaluation of well and geologic data for pre-Tertiary aquifers on the Wind River Indian Reservation, Wyoming

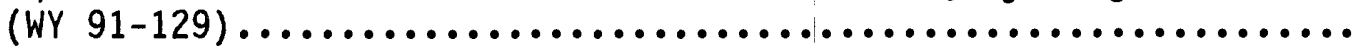

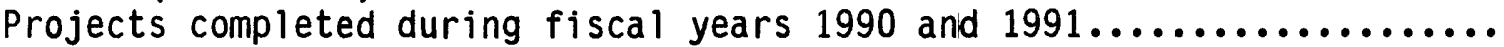

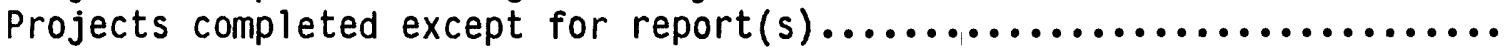

Water-resources information......................................

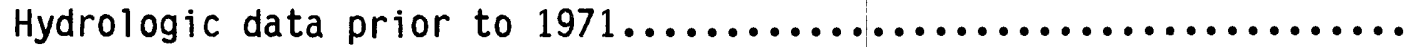

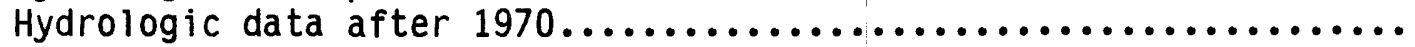

Flood information............................................

Selected publications on water resources............................

General information.........................................

Professional Papers.........................................

Journal of Research of the Geological Survey...................

Water-Supply Papers.......................................

Circulars................................................

Water-Resources Investigations Reports.......................

Water-data reports..........................................

Hydrologic Investigations Atlases.............................

Hydrologic Unit Maps...........................................

Miscellaneous Investigations Maps............................

Open-file reports and maps...................................

Numbered open-file reports..............................

Unnumbered open-file reports...........................

Publications of Wyoming State agencies........................

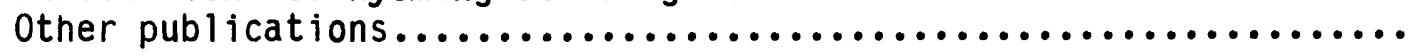


Figure 1. Chart showing Wyoming District organization.............. 8

2. Map showing location of U.S. Geological Survey, Water

Resources Division offices in Wyoming................... 9

3. Diagrams showing sources of funding..................... 10

4-6. Maps showing location of:

4. Streamflow, reservoir, surface-water-quality, and sediment stations, water year $1991 \ldots \ldots \ldots \ldots \ldots \ldots \ldots . .13$

5. Location of ground-water-level observation wells,

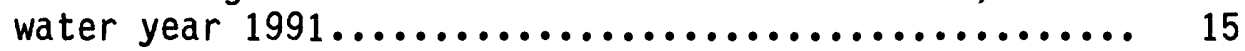

6. Location of ground-water-quality sites, water years

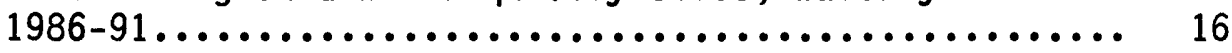

\section{TABLES}

Table 1. Streamflow and reservoir stations........................ 20

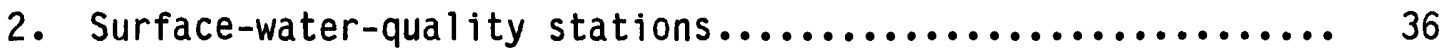

3. Sediment stations................................... 47

4. Ground-water-level observation wells................. 52

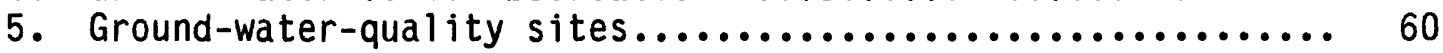

6. Streamflow stations discontinued in water years 1989

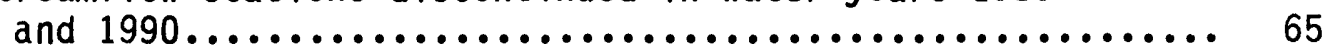

7. Surface-water-quality stations discontinued in

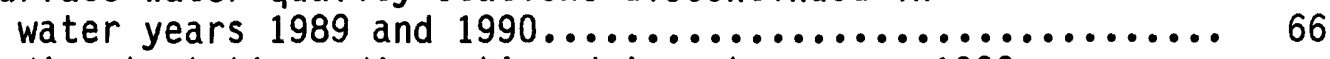

8. Sediment stations discontinued in water years 1989

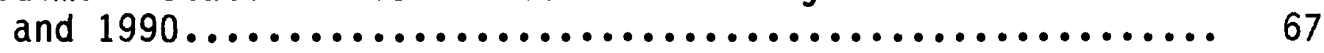

9. Ground-water-level observation wells discontinued in water years 1989 and 1990

\section{CONVERSION FACTORS}

\section{Multiply}

foot

cubic foot per second

gallon per minute

mile

square mile

acre-foot per year
By

0.3048

0.02832

0.06308

1.609

2.590
To obtain

meter

cubic meter per second

liter per second

kilometer

square kilometer

cubic meter per year 


\title{
WATER-RESOURCES ACTIVITIES OF THE U.S. GEOLOGICAL SURVEY IN WYOMING,
} OCTOBER 1989 THROUGH SEPTEMBER 1991

\author{
Compiled by K.E. Wilson
}

\section{ABSTRACT}

This report describes the water-resources activities of the U.S. Geological Survey (USGS), Wyoming District. The activities are classified as data-collection programs and water-resources-appraisal projects. Much of the work is done in cooperation with other agencies. During fiscal years 1990 and 1991, cooperators included 8 State agencies, 4 counties, 3 cities, 1 town, 1 irrigation district, 1 city-county board, 1 tribal co-op, 2 Native American tribes, and 8 Federal agencies. This report serves both as a biennial progress report to the cooperating agencies and the general public, and as one means of coordinating water-resources activities with other agencies.

Lists and location maps are included for 204 streamflow stations, 16 reservoir stations, 110 surface-water-quality stations, 44 fluvial-sediment stations, 90 ground-water-level observation wells, and 97 ground-water-quality sites that were in operation during fiscal year 1990 or 1991 . During fiscal years 1990 and 1991,5 streamflow stations, 23 surface-water-quality stations, 2 sediment stations, and 3 ground-water-level observation wells were discontinued. During fiscal year 1990 and through the first quarter of fiscal year 1991,13 streamflow stations, 9 surface-water-quality stations, and 26 sediment stations were established or reactivated.

Descriptions, location maps, and progress statements are given for 4 data-collection projects and 22 water-resources-appraisal projects that were active (funded) during fiscal year 1990 or 1991. Also included are lists of 8 projects that were completed during fiscal years 1990 and 1991 and 6 projects for which funding ended prior to 1990 and that are completed except for the final report(s). The final section is a bibliographic listing of reports by USGS authors about the water resources of Wyoming.

\section{INTRODUCTION}

The U.S. Geological Survey (USGS) is the Federal agency responsible for appraising the quantity, quality, and distribution of the Nation's surfacewater and ground-water resources. Through its Water Resources Division, the USGS maintains data-collection networks, conducts interpretive studies, and supports hydrologic research in every state, the Commonwealth of Puerto Rico, and the American Trust Territories. It also works through cooperative programs with State, local, and other Federal agencies to help evaluate regional and local water problems. Results of these activities provide a basis for many major water-management decisions. 
The purpose of this report is to describe the water-resources activities in Wyoming. The report also provides information to cooperating officials and the public about the accomplishments in the various appraisal projects during fiscal year 1990 (October 1, 1989 through September 30, 1990) and planned work for fiscal year 1991. The report is one phase of an effort to coordinate the water-resources activities of the USGS with other water-related organizations.

Cooperating State, local, and other Federal agencies are identified throughout this report. The activities are classified into two groups: (1) data-collection programs (projects), and (2) water-resources-appraisal projects.

The data-collection programs include (1) collecting records of streamflow and reservoir storage, (2) sampling and chemical analysis of water from streams and ground-water wells, (3) sampling and analysis of sediment in surface water, and (4) measuring water levels in wells. This report contains tables describing monitoring sites for these four data-collection programs in water year 1991 and sites discontinued in water years 1989 and 1990. All four types of data also are collected as part of many water-resources-appraisal projects; these short-term sites are not included in the tables in this report.

Water-resources-appraisal projects described in this report include the projects conducted during fiscal years 1990 and 1991 . Projects completed prior to fiscal year 1990 , but for which final reports were in preparation at the end of fiscal year 1990, are listed separately. An extensive listing of reports of results from previous activities is provided at the back of this report. 


\section{United States Department of the Interior}

GEOLOGICAL SURVEY

Water Resources Division

2617 East Lincolnway, Suite B

Cheyenne, Wyoming 82001

\section{MESSAGE FROM THE DISTRICT CHIEF}

The Wyoming District, Water Resources Division, U.S. Geological Survey, contributes to the understanding of Wyoming's water resources by monitoring and appraising the water resources of the State. The work we do not only benefits Wyoming, but the Nation as well, because water, whether aboveground in streams and lakes or below ground in aquifers, follows no political boundaries.

As you can see in the pages that follow, our work consists of two groups of interrelated activities: (1) monitoring of water quantity and quality at specific sites, and (2) studies of the hydrology of specific areas and the hydrologic consequences of human activities. The information gathered in both types of activities, including any scientific interpretations of the information, is made avallable to the public as a basis for long-term as well as immediate use in manaing Wyoming's finite water resources.

Over the years, our work has changed in response to changes in needs for water-resources information. Our monitoring-network operations have been and will continue to be the foundation upon which problem-oriented, multidisciplinary hydrologic studies are based. Recent activities include the expansion of our statewide network for monitoring ground-water quality, operation of a network of flood-monitoring stations in and around Cheyenne, and assessments of contamination of ground and surface water by organic compounds and trace elements in selected areas.

Our capacity to carry out investigations is greatly enhanced by our partnerships with State, local, and other Federal agencies. For example, under the unique Federal-State Cooperative Water Resources Program, the Wyoming State Engineer has been our partner in hydrologic-network activities since 1915 and in interpretive studies since the 1940s; this cooperation is continuing. The many other agencies that co-sponsor the work we do are identified throughout this report. Needless to say, the USGS values these partnerships highly.

The next few years will see substantial changes in the field of waterresources investigations as the public becomes more concerned about hazardous wastes and toxic substances in the environment. We will be challenged to develop and use more advanced sampling and analytical techniques to measure chemicals in trace quantities in both ground and surface water. Intrastate water-allocation issues among private, State, and Federal users will require quantification of ground and surface water, even in the absence of detailed studies or long-term records. 
These issues and others will demand attention despite the severe budget constraints imposed by declining State revenues and despite the Federal

deficit. Clearly, increased cooperation between agencies will be essential if we are to meet our obligations. We look forward to the promise of technically challenging programs and stronger cooperative relationships.

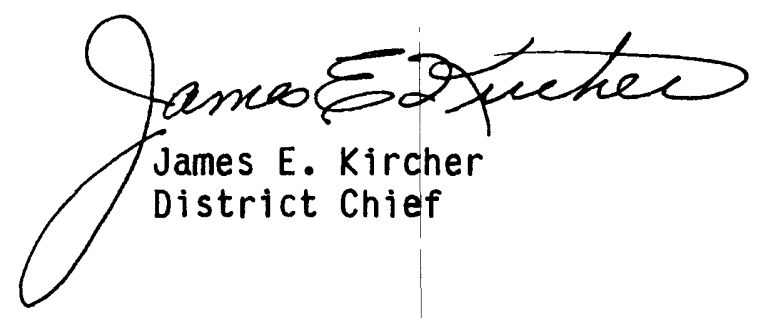


The USGS was established by an act of Congress on March 3, 1879, providing a permanent Federal agency to conduct the systematic and scientific "classification of the public lands, and examination of the geological structure, mineral resources, and products of national domain." An integral part of that original mission includes publishing and disseminating the earthscience information needed to understand, to plan the use of, and to manage the Nation's energy, land, mineral, and water resources.

Since 1879, the research and fact-finding role of the USGS has expanded and been modified to meet the changing needs of the Nation it serves. As part of that evolution, the USGS has become the Federal Government's largest earthscience research agency, the Nation's largest civilian mapmaking agency, the primary source of data on the Nation's surface- and ground-water resources, and the employer of the largest number of professional earth scientists. Today's programs serve a diversity of needs and users. Programs include:

- Conducting detailed assessments of the energy and mineral potential of the Nation's land and offshore area.

- Investigating and issuing warnings of earthquakes, volcanic eruptions, landslides, and other geologic and hydrologic hazards.

Conducting research on the geologic structure of the Nation.

Studying the geologic features, structure, processes, and history of the other planets of our solar system.

- Conducting topographic surveys of the Nation, preparing topographic and thematic maps and related cartographic products.

- Developing and producing digital cartographic data bases and products.

- Collecting data on a routine basis to determine the quantity, quality, and use of surface and ground water.

- Conducting water-resource appraisals in order to describe the consequences of alternative plans for developing land and water resources.

- Conducting research in hydraulics and hydrology, and coordinating most Federal water-data acquisition.

- Using remotely sensed data to develop new research techniques in cartography, geology, and hydrology for natural-resources planning and management.

Providing earth-science information through an extensive publications program.

Along with its continuing commitment to meet the expanding and changing earth-science needs of the Nation, the USGS remains dedicated to its original mission: to collect, analyze, interpret, publish, and disseminate information about the natural resources of the Nation--providing earth science to the public. 


\section{MISSION OF THE WATER RESOURCES DIVISION}

The mission of the Water Resources Division is to provide the hydrologic information and technical evaluation needed for the optimum use and management of the Nation's water resources for the overall benefit of the people of the United States.

This is accomplished, in large part, through cooperation with other Federal and non-Federal agencies, by:

- Collecting, on a systematic basis, data needed for the continuing determination and evaluation of the quantity, quality, and use of the Nation's water resources.

- Conducting analytical and interpretive water-resource appraisals describing the occurrence, availability, and the physical, chemical, and biological characteristics of surface and ground water.

- Conducting basic and problem-oriented research in hydraulics, hydrology, and related fields of science to improve the scientific knowledge for investigations and measurement techniques.

- Disseminating the water data and the results of these investigations and research through reports, maps, computerized information services, and other forms of public releases.

- Coordinating the activities of Federal agencies in the acquisition of water data for streams, lakes, reservoirs, estuaries, and ground water.

- Providing scientific and technical assistance in hydrologic fields to State, local, and other Federal agencies, to licensees of the Federal Power Commission, and to international agencies on behalf of the U.S. Department of State.

\section{ORIGIN OF THE WYOMING DISTRICT}

The Water Resources Division of the USGS, of which the Wyoming District is a part, has its roots in the Irrigation Survey of 1888-90. The Sundry Civil Appropriation Act of 1888 established an Irrigation Survey as a part of the USGS "for the purpose of investigating the extent to which the arid region

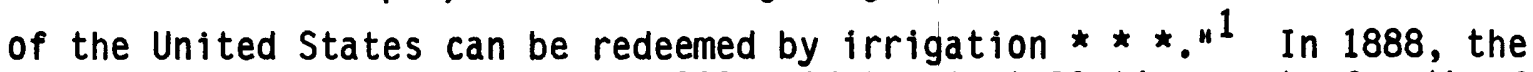
Washington, D.C. office of the USGS paid the installation costs for the first streamflow-gaging station in Wyoming, Laramie River at Woods Landing. The station was constructed and operated by the Territorial Engineer, Elwood Mead. Between 1895 and 1901, the USGS paid operating expenses for additional stations operated by the Wyoming State Engineer. A.J. Parshall became the first resident hydrographer for the USGS in Wyoming in 1901.

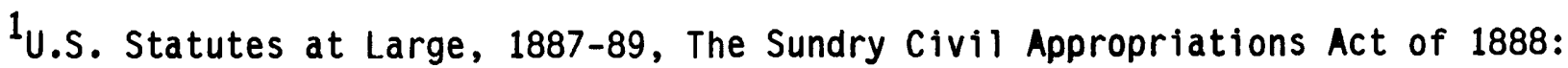
Washington, v. 25, chap. 1069, p. 526 . 
These early activities were forerunners of the Federal-State Cooperative Water-Resources Program, first funded by Congress in 1905, and given formal recognition by Congress in 1927. The Cooperative Program is a partnership among the USGS and State and local agencies for water-resources investigations.

Surface-water investigations in cooperation with the State Engineer have continued without interruption since 1915. Early Federal cooperators included the Reclamation Service (about 1902), the Indian Service (1908), and the Forest Service (1910). A flood-investigations program was started in 1959 in cooperation with the Wyoming Highway Department; this successful program was completed in 1988.

Surface-water activities in Wyoming were directed from Washington until 1903, when the Colorado District was established under M.C. Hinderlider. Between 1903 and 1961, Wyoming was part of the Colorado District, with local offices at various times in Kemmerer, Sheridan, and Casper. The Wyoming District, Surface Water Branch, was established in 1961, with L.A. Wiard as District Engineer.

The earliest known ground-water studies by the USGS in Wyoming were done between 1901 and 1917 by G.I. Adams in Goshen Hole area; N.H. Dartion and others in the Great Plains, Bighorn Mountains, Laramie Range, and Black Hills; and 0.E. Meinzer in Lodgepole Valley. Investigations in cooperation with State agencies have been carried out since 1940, when the Wyoming Planning and Water Conservation Board sponsored a study of the Egbert-Pine Bluffs area by T.W. Robinson. Cooperation on hydrologic studies with the State Engineer has continued since 1945 .

Ground-water work in Wyoming was directed from Washington until 1945 , when Wyoming became a part of the Colorado District under S.W. Lohman. The local geologist in charge was A.M. Morgan. In 1951 the Wyoming District, Ground Water Branch, was established with H.M. Babcock as District Geologist.

Surface-water quality work in Wyoming began with the establishment of an office and sediment laboratory in Worland in March 1946, with T.F. Hanly in charge. The program was directed by P.C. Benedict, Regional Engineer, in Lincoln, Nebraska. During 1948, chemical-quality or sediment stations were in operation in the North Platte River basin under the Missouri River basin program of the U.S. Department of the Interior.

In February 1956, the office in Worland was designated as a District Office, Quality of Water Branch, with T.F. Hanly as District Engineer. The first sediment station in the State cooperative program was established on Rock Creek near Atlantic City with the Wyoming Natural Resources Board in 1957. A cooperative chemical-quality program with the State Engineer was started in 1959 to evaluate the effects of the Kendrick Project on the North Platte River. Since 1965, the Wyoming Department of Agriculture has been the principal State cooperator for chemical quality, and the State Engineer for sediment data. The Branch Districts in Wyoming were combined into a single Water Resources Division District in February 1967 with L.A. Wiard as District Chief. 


\section{DISTRICT ORGANIZATION}

The water-resources activities of the Wyoming District office are carried out by two operating sections (fig. 1) and two support sections. The Hydrologic Surveillance and Data Management Section designs, constructs, operates, and maintains the District's hydrologic-data stations and manages the collection, analysis, publication, and storage of hydrologic data. The Hydrologic Investigations Section plans and executes water-resources investigations Statewide, including mathematical modeling of ground-water systems, application of open-channel hydraulics to surface-water problems, water-resources appraisals, hazardous-waste investigations, and evaluation of the hydrologic effects of human activities such as irrigation of croplands or surface mining of coal. Administrative Services Section provides support to the rest of the District in the form of program planning and management, budgeting, accounting, personnel management, property inventory, travel records, vehicle management, and related services. The Computer support Unit designs and maintains the computer systems and provides computer services to the rest of the District. The Publications Support Unit is part of the Hydrologic Investigations Section and is responsible for adequacy of publications and adherence to Survey and Division policy and format; the Unit assists the District staff in the design, preparation, and processing of publications. All reports also are reviewed by the Reports Specialist for technical correctness and adherence to policy.

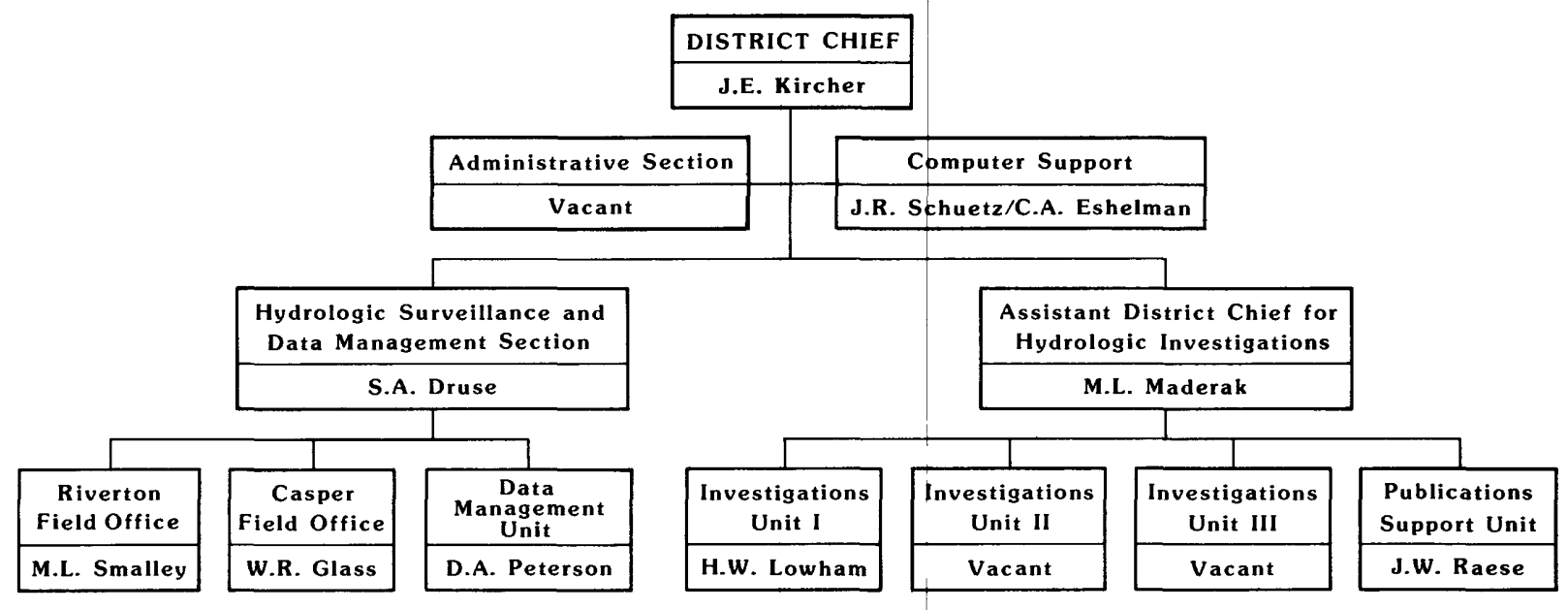

Figure 1.--Wyoming District organization. 
The District Office is in Cheyenne, with Field Offices in Casper and Riverton (inside front cover and fig. 2). Personnel of the Field offices perform most of the hydrologic-data collection; the Casper office is responsible for eastern Wyoming, and the Riverton office is responsible for western Wyoming.

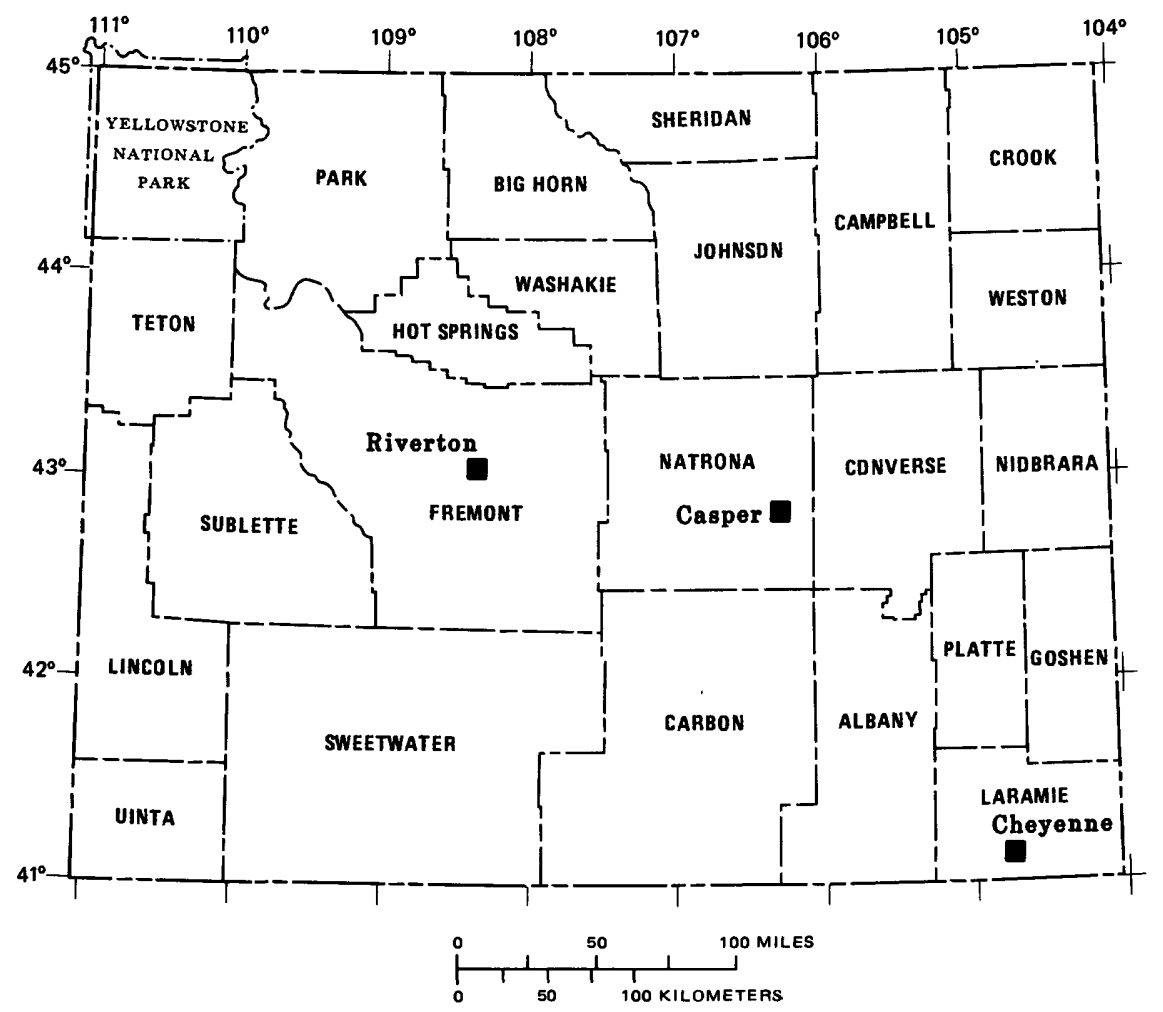

Figure 2.-Location of U.S Geological Survey, Water Resources Division offices in Wyoming. 


\section{SOURCES OF FUNDING}

Funds for carrying out the water-resources investigations of the U.S. Geological Survey (USGS) in Wyoming are provided by many agencies. The agencies are classified by three major categories: (1) State and local agencies that provide funds or services, or both, generally matched on a 50-50 (percent) basis by USGS funds (cooperative program); (2) other Federal agencies that transfer funds to the USGS (OFA program); and (3) USGS funds received by direct appropriation for activities that are national in scope (Federal program). The distribution of these funds in Wyoming by major category for fiscal years 1990 and 1991 is shown in figure 3. During fiscal year 1990, about 50 percent of the funds were used for collection of hydrologic data and about 50 percent for interpretive hydrologic studies, while in 1991 the distribution is 30 percent hydrologic data and 70 percent hydrologic studies.

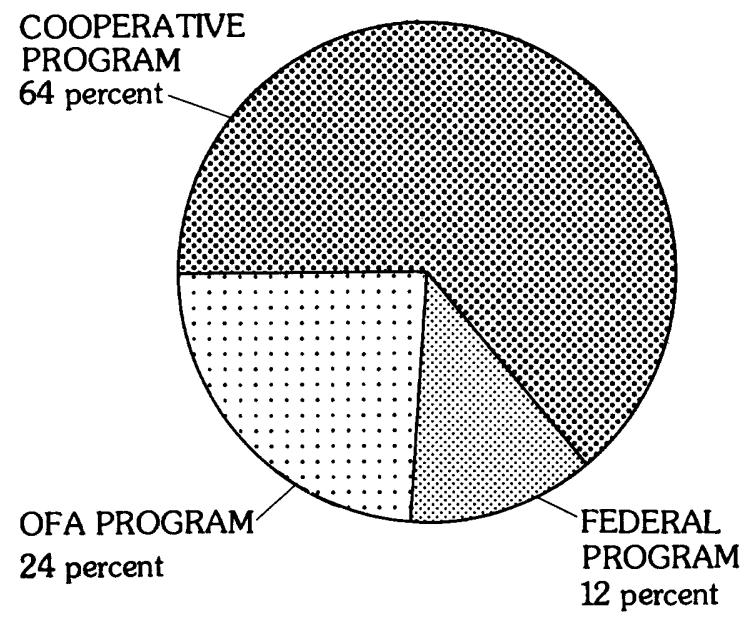

FISCAL YEAR 1990

TOTAL ABOUT $\$ 3,515,000$

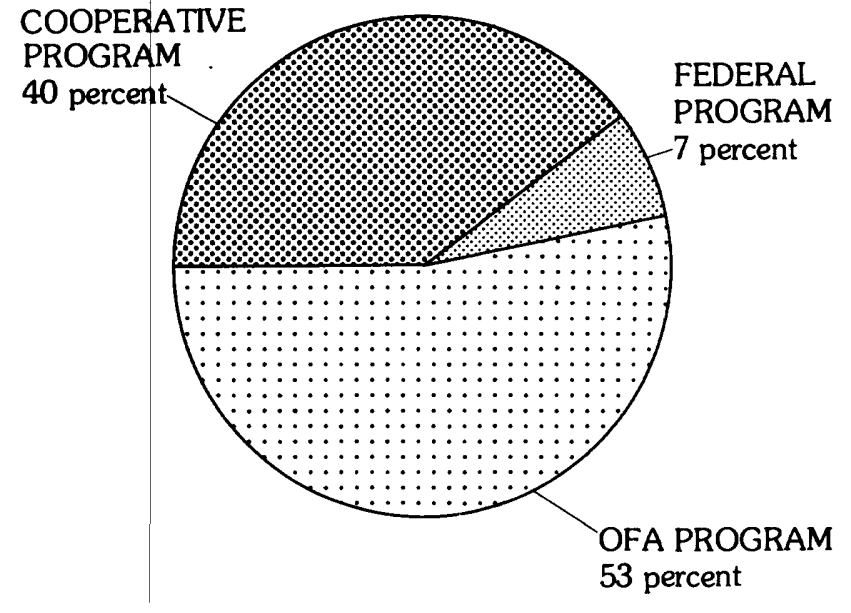

FISCAL YEAR 1991

TOTAL ABOUT $\$ 6,300,000$

Figure 3.-Sources of funding. 
Drought conditions persisted throughout most of Wyoming during water year 1990, with only extreme eastern and extreme northwestern Wyoming having near normal conditions. The Weekly Weather and Crop Bulletin, prepared and published by the National Oceanic and Atmospheric Administration (NOAA) and the U.S. Department of Agriculture Joint Agricultural Weather Facility, reported little change from 1989 in the area affected by severe and extreme drought during the summer months. The july 7 report showed the area of extreme drought included all of Wyoming except extreme eastern and extreme northwestern Wyoming, and this condition prevailed through their September report. Water year 1990 was the third consecutive year of drought throughout most of Wyoming.

\section{Precipitation}

Precipitation during water year 1990 was greater than during the previous year; most of the State received more than 85 percent of the 1951-80 average. Precipitation and departures from normal (1951-80 average) for the major divisions (drainage basins) are published by NOAA. The Bighorn and Lower [North] Platte basins received greater-than-average precipitation--the Bighorn basin in northwestern Wyoming received 108 percent and the Lower [North] Platte basin in eastern Wyoming received 125 percent. The Green River and Bear River basins in southwestern Wyoming received the least--77 percent.

Basins in eastern and north-central Wyoming received greater-than-average precipitation during the autumn and winter months (October through March), and the remainder of the basins recorded less-than-average precipitation during the period. The spring months (April through June) were dry throughout the State, with all basins recording less than average precipitation. Precipitation increased to near average or greater than average during the summer months (July through September); only the Powder River, Little Missouri River, and Tongue River basins in northeastern Wyoming recorded less than near average precipitation.

Precipitation in the mountains, as snow, provides most of Wyoming's annual water supply. For the third consecutive year, the snowpack in the mountains throughout most of the State was less than average. The U.S. Soil Conservation Service noted in the May 1, 1990 issue of Basin Outlook Reports that only the Bighorn Mountains had a snowpack that was near or slightly above average. The remainder of the State's mountains had snowpacks that were below average. Most were 75 to 90 percent of average; however, the Black Hills had a snowpack that was only 19 percent of average, mountains along the southwest edge had snowpacks that were 16 to 29 percent of average, and mountains in the upper Green River basin had snowpacks that were 55 percent of average. The report also noted that melting of the snowpacks started $21 / 2$ to 3 weeks earlier than normal. 


\section{Streamflow}

Monthly and annual discharge in most streams reflected the drought conditions that were prevalent in a large part of the State. The annual average discharges at most of these stations were at or below the 25 th percentile. Some stations recorded average flows for water year 1990 that were near the minimum for the period of record, but generally exceeded the average discharge for water year 1989, when several stations recorded new minimums.

\section{Floods}

Flooding, particularly from snowmelt, was moderate throughout the State during water year 1990. The moderate maximum discharges generally reflected the continuing drought and the earlier-than-normal snowmelt. Summer thunderstorms, however, caused locally severe flooding in several streams. Of particular significance was the flood on Sybille Creek in Platte County on August 20. Maximum discharges of record were recorded at station 06664400 , Sybille Creek above Mule Creek, near Wheatland $(19,900$ cubic feet per second) and at station 06665790, Sybille Creek above Canal No. 3, near Wheatland $(6,900$ cubic feet per second). The flood at station 06664400 was six times greater than the theoretical 100-year flood as determined from station discharge records, and the flood at station 06665790 was three times greater. Damage was limited to roads and bridges, agricultural land, and livestock. Only one rural home was known to have sustained damage. The location of the stations is shown in figure 4 .

\section{Chemical Quality of Surface Water}

Specific conductance of streamflow during water year 1990 was not significantly different from that of the previous 10 years, on the basis of data from five of seven water-quality stations selected to represent the major drainages of Wyoming. Specific conductance was chosen as an indicator of dissolved-solids concentration in water because the conductance varies directly with the concentration and species of ions in the water. At station 06317000 , Powder River at Arvada, and station 09217000, Green River near Green River, the mean specific conductance for water year 1990 was significantly different from the mean of the previous 10 years. The specific conductance in the Powder River was smaller in 1990 than in previous years, probably because of change in discharge from Salt Creek, a tributary upstream from station 06317000 . Before 1990 , about 25 to 30 percent of the dissolved solids of the Powder River came from Salt Creek according to a report from the Wyoming Department of Environmental Quality, Wyoming 1988 Water Quality Assessment by D.W. Hogan. During 1990, discharges from oil and gas production along Salt Creek were substantially reduced (John Wagner, Wyoming Department of Environmental Quality, oral commun., 1990). The mean specific conductance of the Green River also was smaller in 1990 than in previous years, for unknown reasons. The location of surface-water-quality stations is shown in figure 4 . 


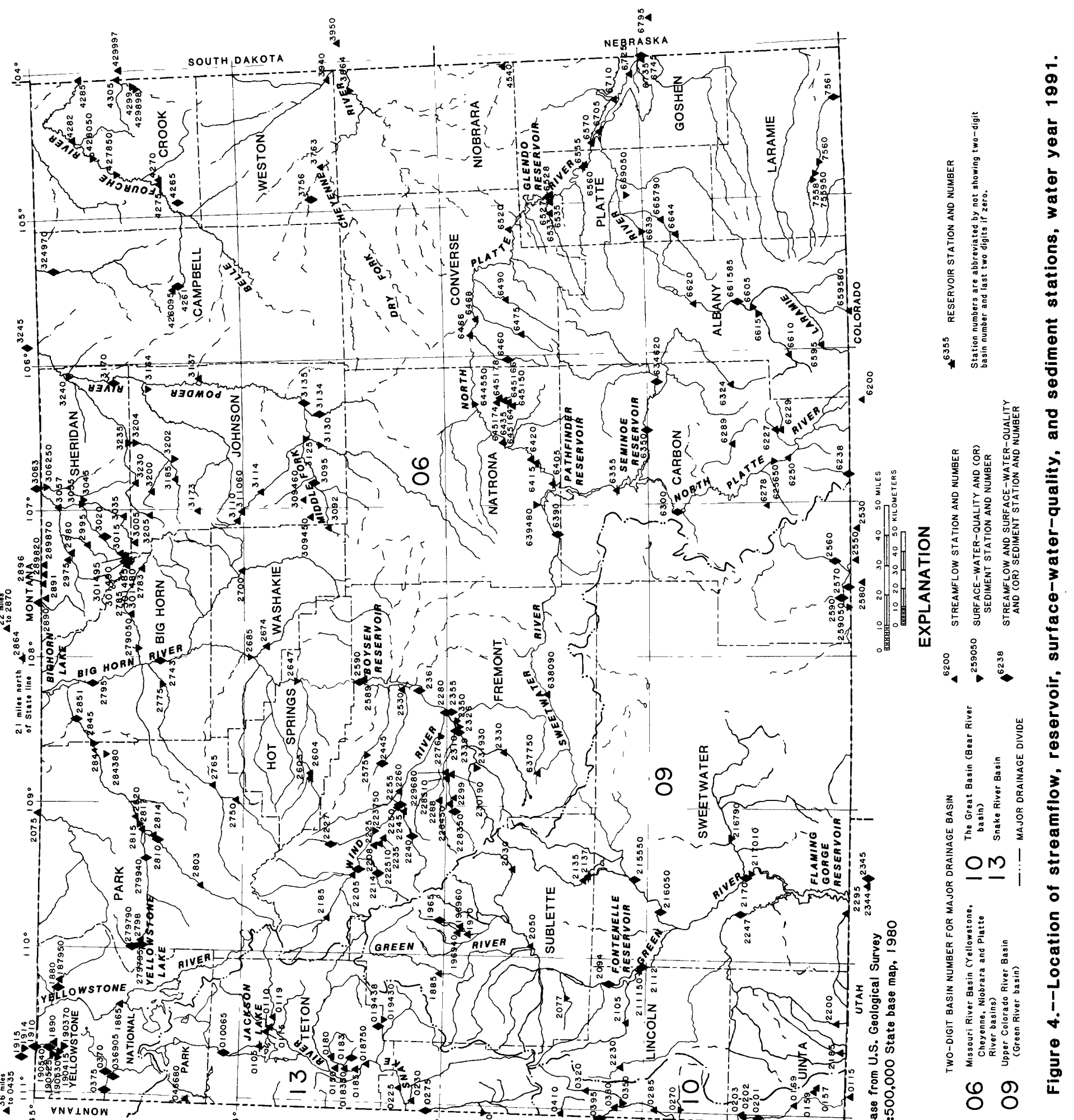




\section{Ground-Water Levels}

Water levels in most wells in the statewide observation-well network declined during water year 1990. Most of the 90 wells in the observation-well network are in areas of extensive ground-water withdrawal--mainly in southeastern Wyoming (fig. 5). Water in Niobrara, Goshen, and eastern Laramie Counties is withdrawn from the High Plains aquifer for irrigation; water in Platte County is withdrawn from alluvium for irrigation. Water in central Laramie County is withdrawn from the High Plains aquifer for domestic use.

The rate of decline during 1990 was less than that of 1989, attributed largely to the greater-than-average precipitation during the summer in eastern Wyoming. Water levels in all but one of the network wells in Goshen County declined from the previous year; declines ranged from 0.3 foot to about 1.7 feet. The water level in one well declined 2.0 feet. Changes in water levels in Niobrara County ranged from a 0.3 -foot rise in one well to declines of 1.9 feet or less in others. Measured changes in 18 network wells in Laramie County ranged from a rise of about 3.0 feet to a decline of 5.0 feet; the median change for all network wells in Laramie County was a decline of 0.6 foot. Water levels in 11 network wells in Platte County ranged from a 3.0foot rise from the previous year to a decline of about 5 feet; the median change from 1989 levels was a decline of 0.8 foot.

The location of all wells in the observation-well network and hydrographs of water levels are published in separate reports by the USGS. The most recent water-level report Ground-Water Levels in Wyoming, 1980 Through September 1989 , by Hugh I. Kennedy and Sharon L. Green, is available for inspection at the USGS office in Cheyenne.

\section{Ground-Water Quality}

The quality of ground water ordinarily changes slowly; therefore, for most general purposes, one annual sampling, or only a few samples, taken at selected sites at infrequent intervals during the year, is sufficient to define ground-water quality. The location of ground-water-quality sites for 1986-91 is shown in figure 6. All wells sampled are pumped long enough to assure the water collected is representative of the aquifer.

\section{WYOMING WATER ISSUES}

Wyoming's economy is dominated by agriculture, recreation, tourism, and the minerals industry; consequently, water issues tend to focus on the traditional agricultural base of the economy, the quality of recreation resources, and the development of oil and gas, coal, uranium, and other minerals. Major water issues by category are summarized below. 


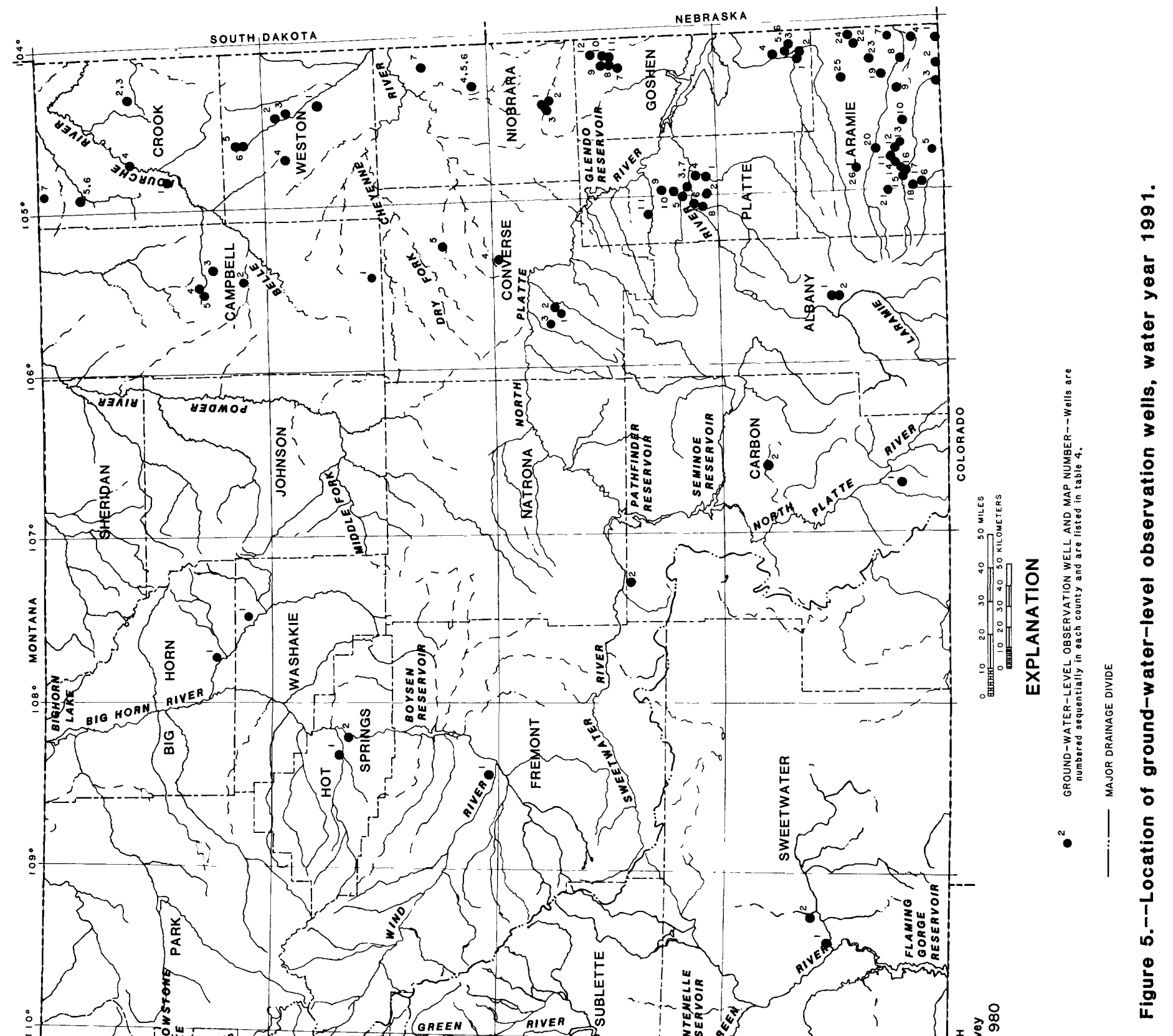




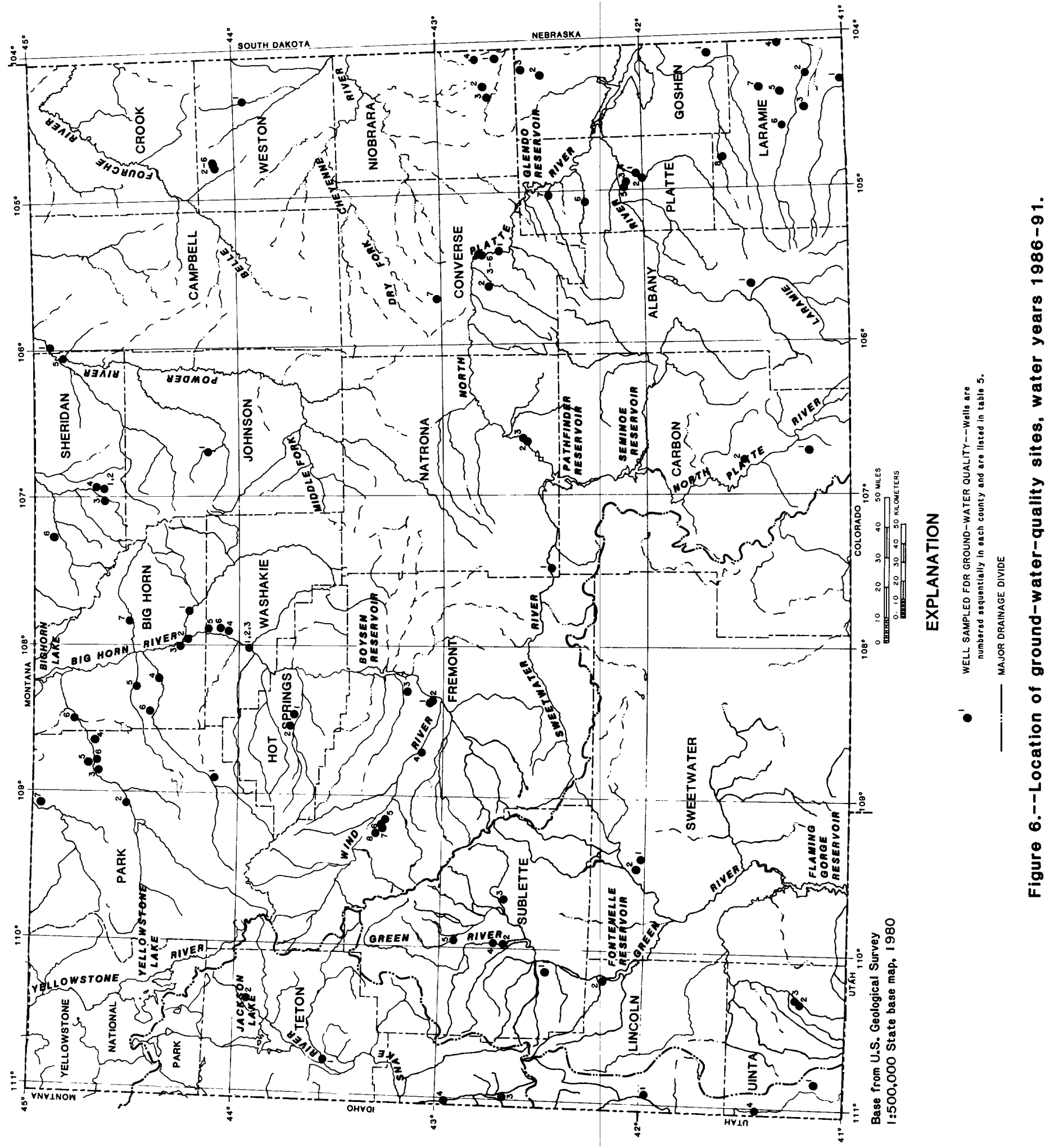




\section{Surface-Water Issues}

Most of the surface water in the State is committed under provisions of interstate compacts and court decrees; unused water is allowed to flow to downstream states. Surface water is abundant in some parts of the State and is scarce in others. The uneven distribution of surface water areally and throughout the year is a constraint on agricultural and industrial development, and results in competition for available surface-water supplies. Most competition for supplies is among agricultural, municipal, and industrial users on the water-short plains. New storage and diversion structures are being planned to meet future surface-water needs.

Many irrigation projects in Wyoming were developed with inadequate provisions for drainage. As a consequence, ground-water levels in some areas have risen to the land surface and caused wetlands that are untillable during parts of the year or have become alkaline because of the accumulation of salts. Thousands of acres of formerly irrigated farmlands are unsuitable for cultivation because of the accumulation of alkaline deposits. The wetlands created by irrigation practices are a loss to agriculture but locally provide wildlife habitats.

\section{Surface-Water-Qual ity Issues}

Surface-water-quality issues include salinity, suspended sediment, nutrients, and pesticides. New emphasis is being placed on monitoring and abatement of nonpoint-source pollution, such as from natural runoff and from agriculture. Salinity is a problem in the Green River basin. Irrigation return flows from the Big Sandy River have increased the average dissolvedsolids load by 49 percent. Changing irrigation practices in the Big Sandy irrigation area from direct application to pivot-sprinkler systems is a method being tested to reduce dissolved-solids loads by the elimination of return flows. Phosphorus, primarily from natural sources, is enriching the water and bottom sediment in many of the larger reservoirs in the State. The adverse effects of eutrophication are most noticeable in Flaming Gorge Reservoir in southwestern Wyoming.

Two other surface-water-quality issues are acid precipitation and elevated selenium concentrations. Studies such as the glacial ice-core project have focused primarily in the high elevations of the Wind River Range. Lakes and streams in the mountain areas are susceptible to acidification because of the lack of alkaline soils to neutralize acid precipitation. Studies have been conducted to evaluate large concentrations of selenium in samples from water, bottom sediment, and biota in irrigation areas near Riverton and Casper.

\section{Ground-Water Issues}

In many parts of the State, ground water is the only source of water because surface water is absent, unreliable, or already appropriated. Most of the State's population is served by ground water, and most ground water is used for irrigation and industrial supplies. Depending on location in the State, most important issues are related to availability and the hydrologic 
effects of energy-resource development. Development of coal methane from shallow coal aquifers has the potential of depleting ground-water resources near areas of development. Declining water levels associated with irrigation and residential use in the southeastern part of the State might require conservation measures that restrict future development. In many places, ground water in shallow aquifers, particularly alluvium, is connected hydraulically to adjacent streams. Because of this connection, the development of shallow ground-water supplies is likely to be constrained by the potential effects on previously appropriated surface water.

\section{Ground-Water-Quality Issues}

Ground-water quality differs greatly between and within aquifers throughout Wyoming. Dissolved-solids concentrations commonly are large. Where dissolved-solids concentrations are large, usually the concentration of sulfate and chloride are large also. Naturally occurring large concentrations of fluoride, selenium, iron, manganese, radionuclides, and hardness are also common to many areas of the State. Much of the ground water is naturally hard. Large concentrations of nitrate mostly are associated with human activities and are most common in water from alluvial aquifers or from other aquifers at shallow depths. Large concentrations of fluoride generally are found in water from basin-type aquifers at depth. Concentrations of toxic metals, such as dissolved arsenic, barium, cadmium, chromium, lead, and mercury, are present in most aquifers, but generally do not limit the use of water in Wyoming. Large concentrations of iron and manganese, which are objectionable for esthetic and economic reasons, are fairly common in ground water used for domestic supplies.

Despite the small population density, ground water has been contaminated in localized areas by human activities associated with waste disposal, agriculture, mineral extraction and processing, and urbanization. Hazardous wastes have been or are being disposed of at sites in five counties. At some sites, soils, ground water, or both have been contaminated by chemicals such as benzene, ethylbenzene, toluene, xylene, chloride, sulfate, and phenol. Irrigation can increase the concentration of dissolved solids in shallow aquifers. Salts accumulate in the soll after evapotranspiration has consumed the water. Some of the applied irrigation water transports these salts down to the water table. Contamination by nitrate is common in agricultural areas. Nitrates are leached from corrals and feedlots into ground water. Nitrate fertilizer used on crops also may increase nitrate concentrations in ground water. Large nitrate concentrations have been detected in ground-water samples in wells in six counties.

Large dissolved-solids concentrations in ground water have been associated with spoil material at coal mines and tailings and at disposal sites at trona mines. Concentrations of dissolved solids in spoil water at mine sites generally are larger than concentrations in water from nearby stock and domestic wells, but some ground water from spoil material is acceptable for use by livestock. Experimental underground coal-gasification burns and oil-shale retort sites have contaminated ground water locally in four counties. Increased concentrations of dissolved solids, sulfate, chloride, 
radionuclides, and trace metals generally are associated with mineral extraction and processing. Complex hydrocarbon compounds are associated with $0 i 1$ and gas exploration, development, and refining processes.

Sources of ground-water contamination in urban areas include leaking underground petroleum-product storage tanks and septic-tank leach fields. Leaking gasoline and diesel fuel storage tanks in or near urban areas and various small communities have contaminated local ground water. In many urban areas, wells have been contaminated as a result of too many septic tanks, or disposal systems are too small for the number of individuals served. Nitrate is a major ground-water contaminant.

\section{DATA-COLLECTION SITES}

Data-collection sites and the hydrologic data being collected at each are given as follows: table 1 , streamflow and reservoir stations; table 2 , surface-water-quality stations; table 3, sediment stations; table 4, groundwater-level observation wells; and table 5, ground-water-quality sites. The data-collection sites that were discontinued during water years 1989 and 1990 are listed in tables 6-9.

Water year is one of three types of time measurement used in this report: the calendar year is from January 1 to December 31 of a particular year; the water year and the fiscal year are identical, from October 1 through September 30; the numerical designation of a water year or fiscal year is the year of completion of the time period. Stations listed in tables 1-4 are in operation during water year 1991; however, the period of record given is in calendar years. The period of record for the stations listed in tables 5-9 is in water years.

Station numbers for stations listed in tables 1-3 conform with the standard downstream order for listing stations within each major river basin. The first two digits of the assigned eight-digit number, such as 06207500 , identifies the major river basin in which the stream resides. For example, digits "06" refer to the Missouri River basin. The remaining six digits identify the relative position of the station, with numbers increasing in the downstream direction.

The local well numbers 1 isted in tables 4 and 5 are based on the Federal system of land subdivision. A detailed explanation of this system can be found preceding tables 4 and 5 . The wells are listed in numerical order by county.

Abbreviations and codes are used to indicate other information about the operation of the data-collection sites. Explanations of the abbreviations and codes precede each table.

The location of streamflow, reservoir, surface-water-quality, and sediment stations is shown in figure 4 . The station numbers are abbreviated by not showing the two-digit number and the last two digits if zero. The location of ground-water-level observation wells is shown in figure 5 . The location of ground-water-quality sites is shown in figure 6 . 
Table 1.--Streamflow and reservoir stations

Explanation of abbreviations and codes used in table 1

Period of record: The dates given are the calendar years in which records began or ended.

Gage equipment:

D digital recorder $\quad T$ telemark

$G$ graphic recorder W well gage

$M$ manometer gage

$P$ satellite-relay platform

Data frequency:

$S$ seasonal operation (no winter records)

$Y$ full-year operation

Field office:

C Casper

$\mathrm{CH}$ Cheyenne

CO Colorado District

ID Idaho District

MT Montana District

NE Nebraska District

$R$ Riverton

$S$ Wyoming State

SD South Dakota District

UT Utah District

Funding agency:

BRUC Bureau of Reclamation, Colorado Region

BRUM Bureau of Reclamation, Missouri Region

CE Corps of Engineers

MRB U.S. Geological Survey, support for other Interior Agencies

GILL City of Gillette

MID Midvale Irrigation District

SJPB Sheridan Area Water Supply-Joint Powers Board

TC Teton County

UC Uinta County

USFS Forest Service

USGS U.S. Geological Survey, Federal Program

WDEQ Wyoming Department of Environmental Quality

WRIR Wind River Indian Reservation, Northern Arapaho and Shoshone Tribes

WSE Wyoming State Engineer

WWDC Wyoming Water Development Commission

WWRC Wyoming Water Research Center

-- Not funded through Wyoming District

\section{Remarks:}

HBM hydrologic benchmark station

NASQAN national stream-quality accounting network station

QW also water-quality station

SED also sediment station

USBR furnished by U.S. Bureau of Reclamation 


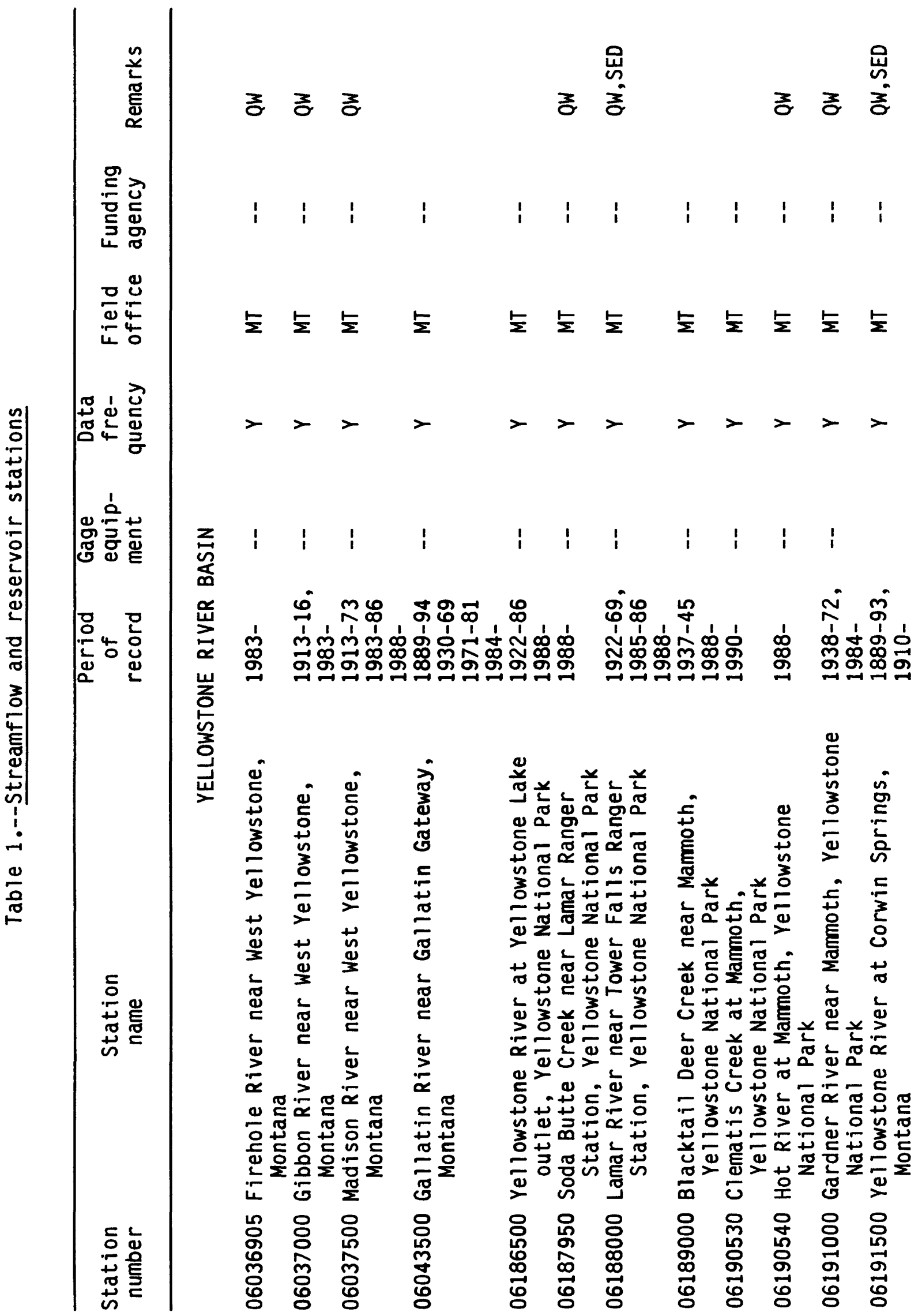




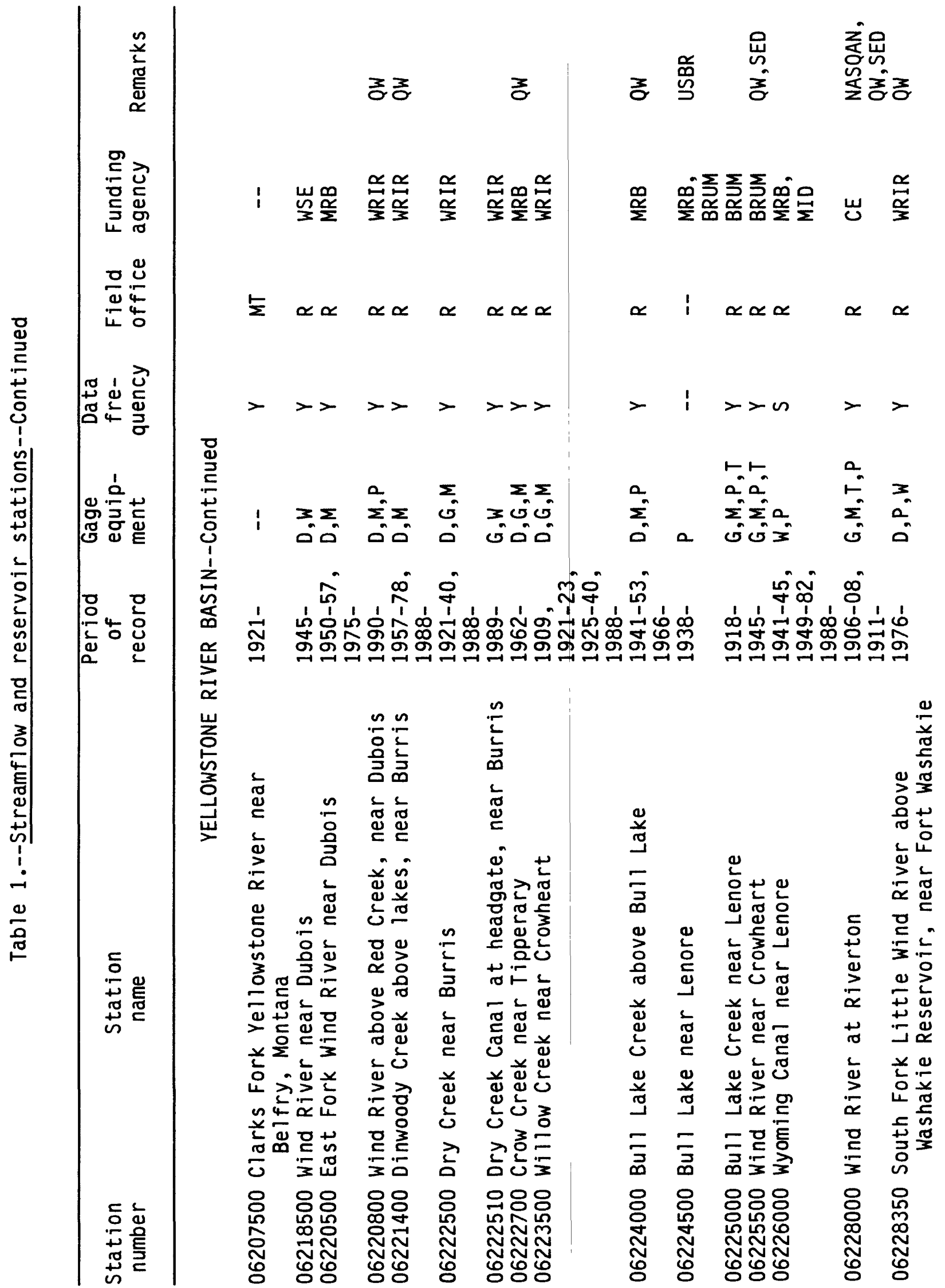




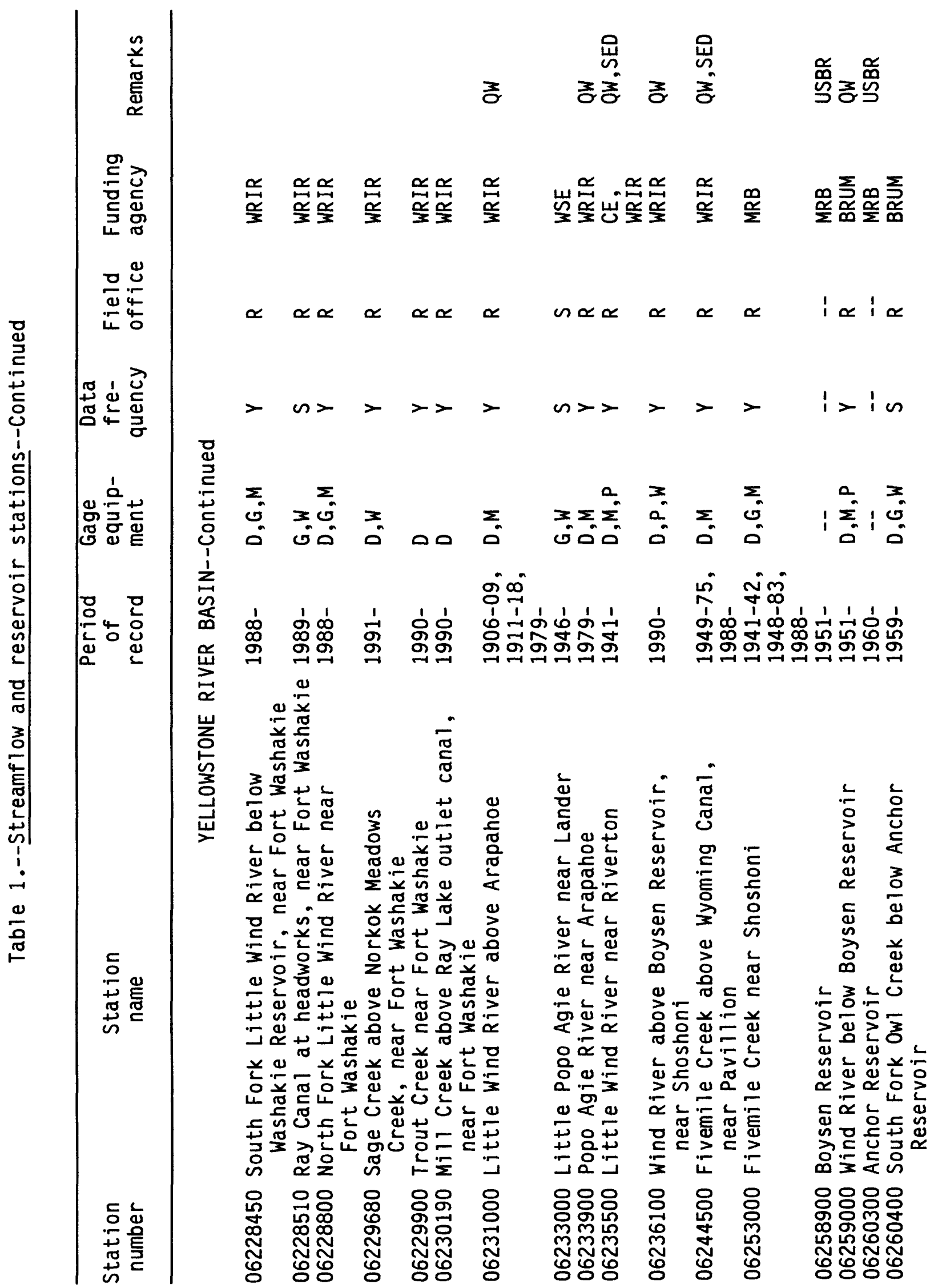




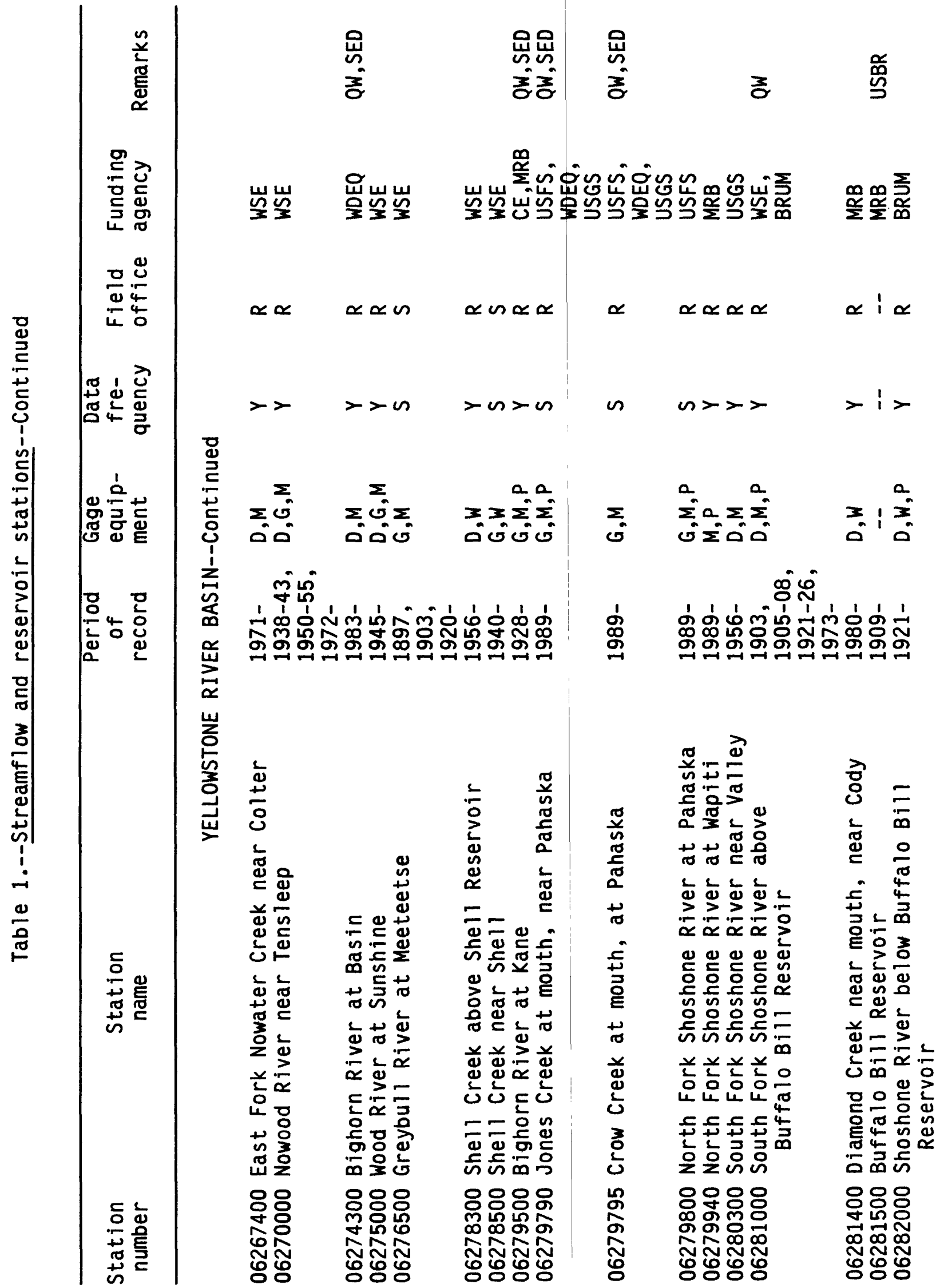




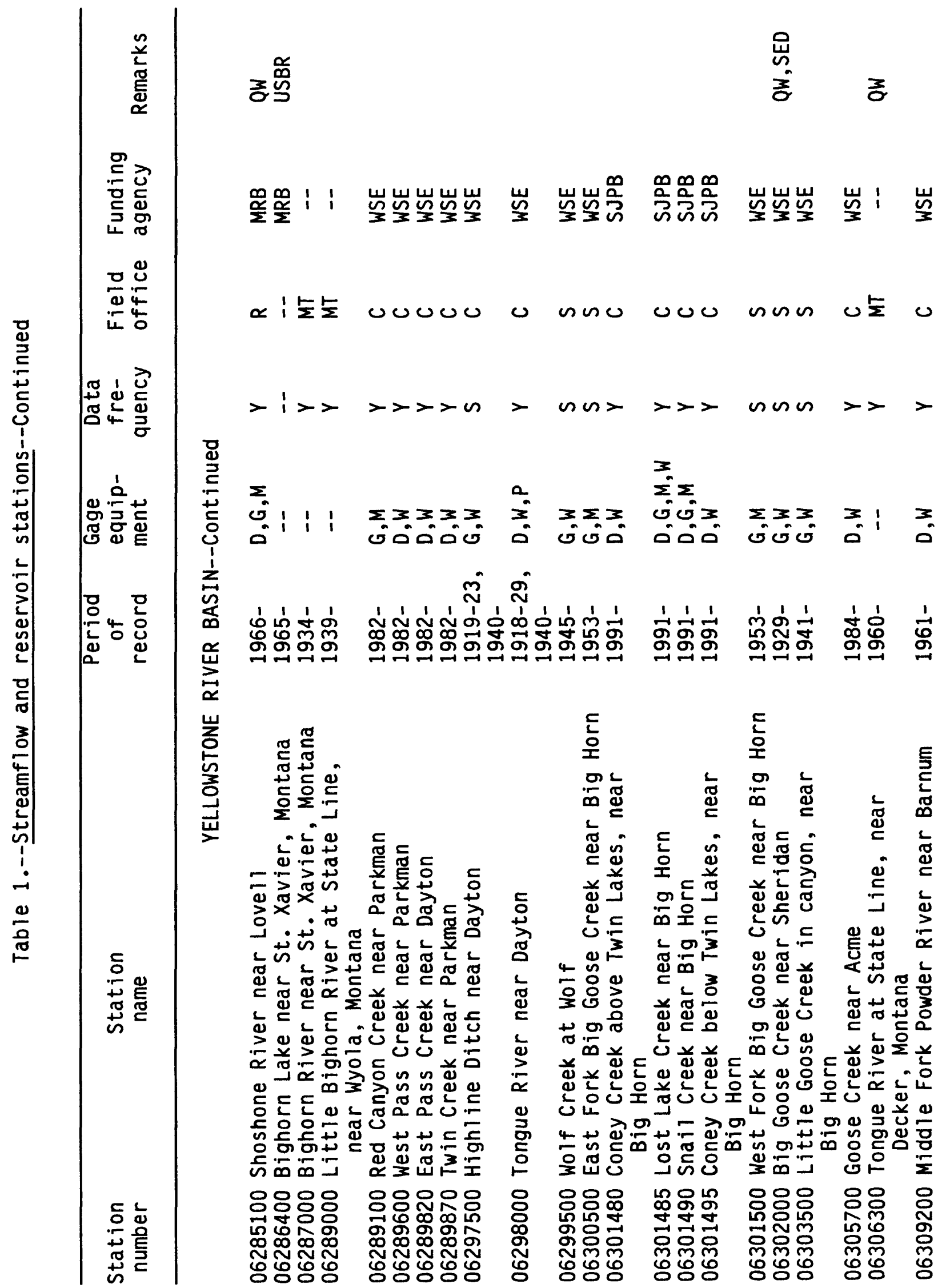




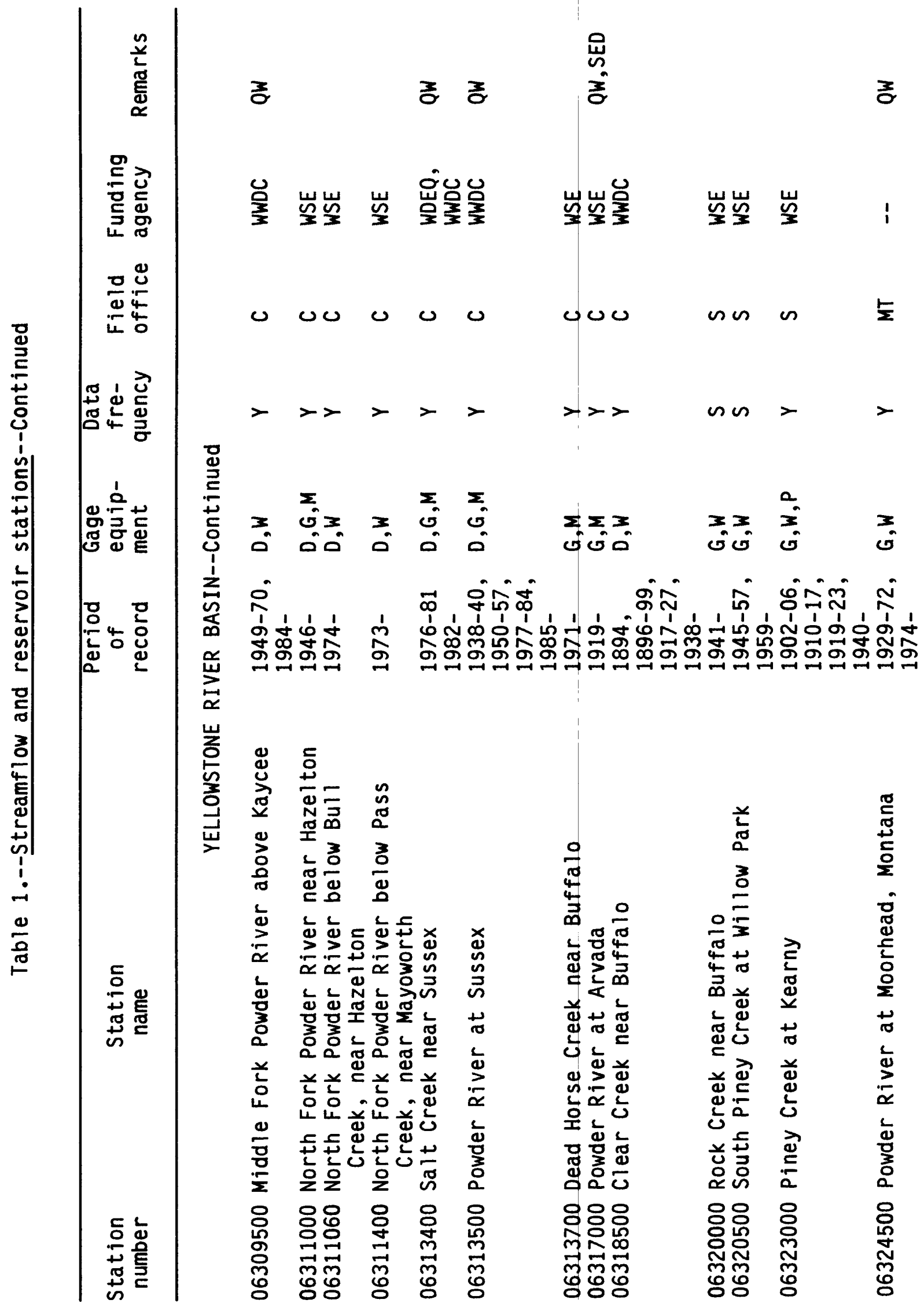




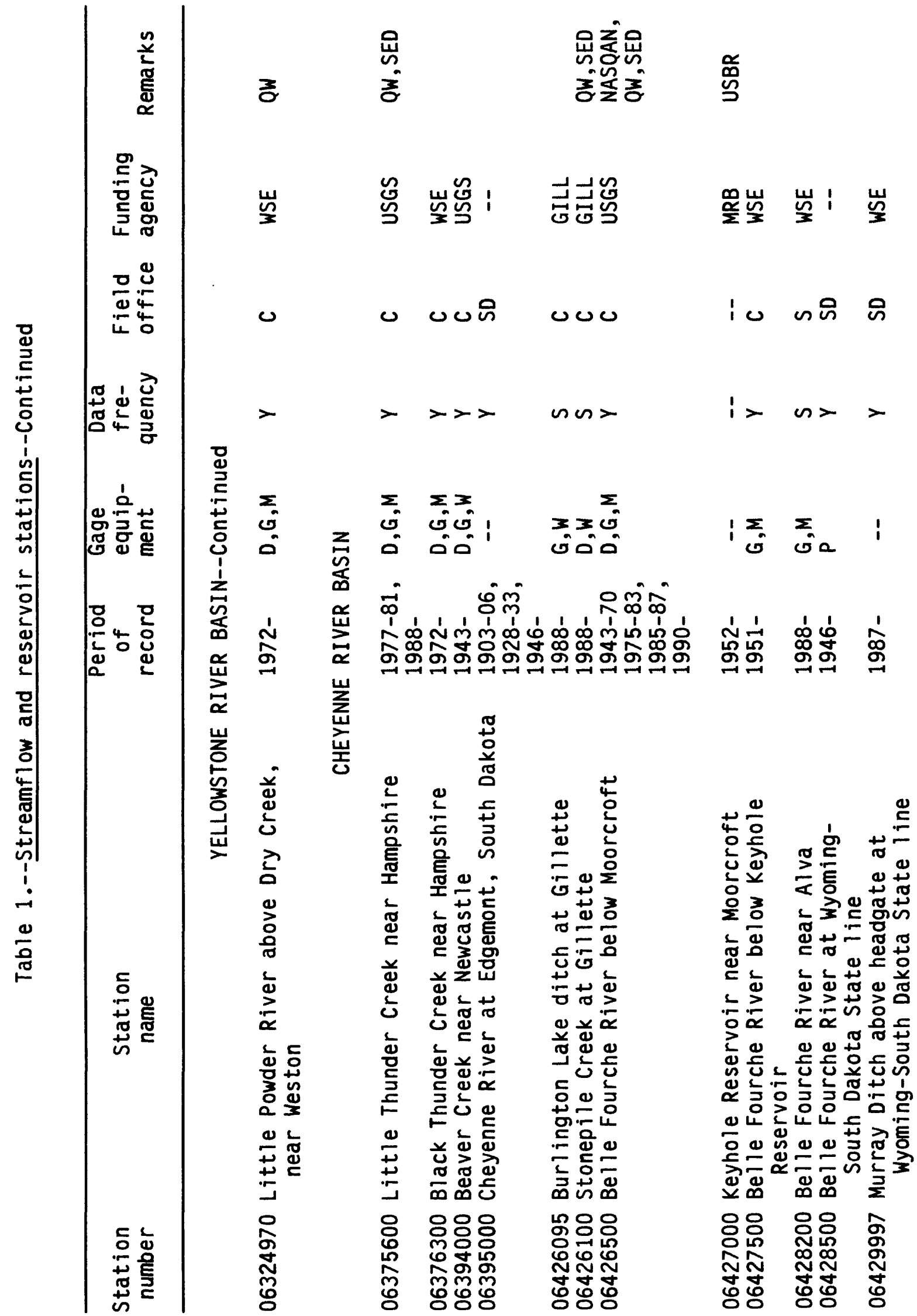




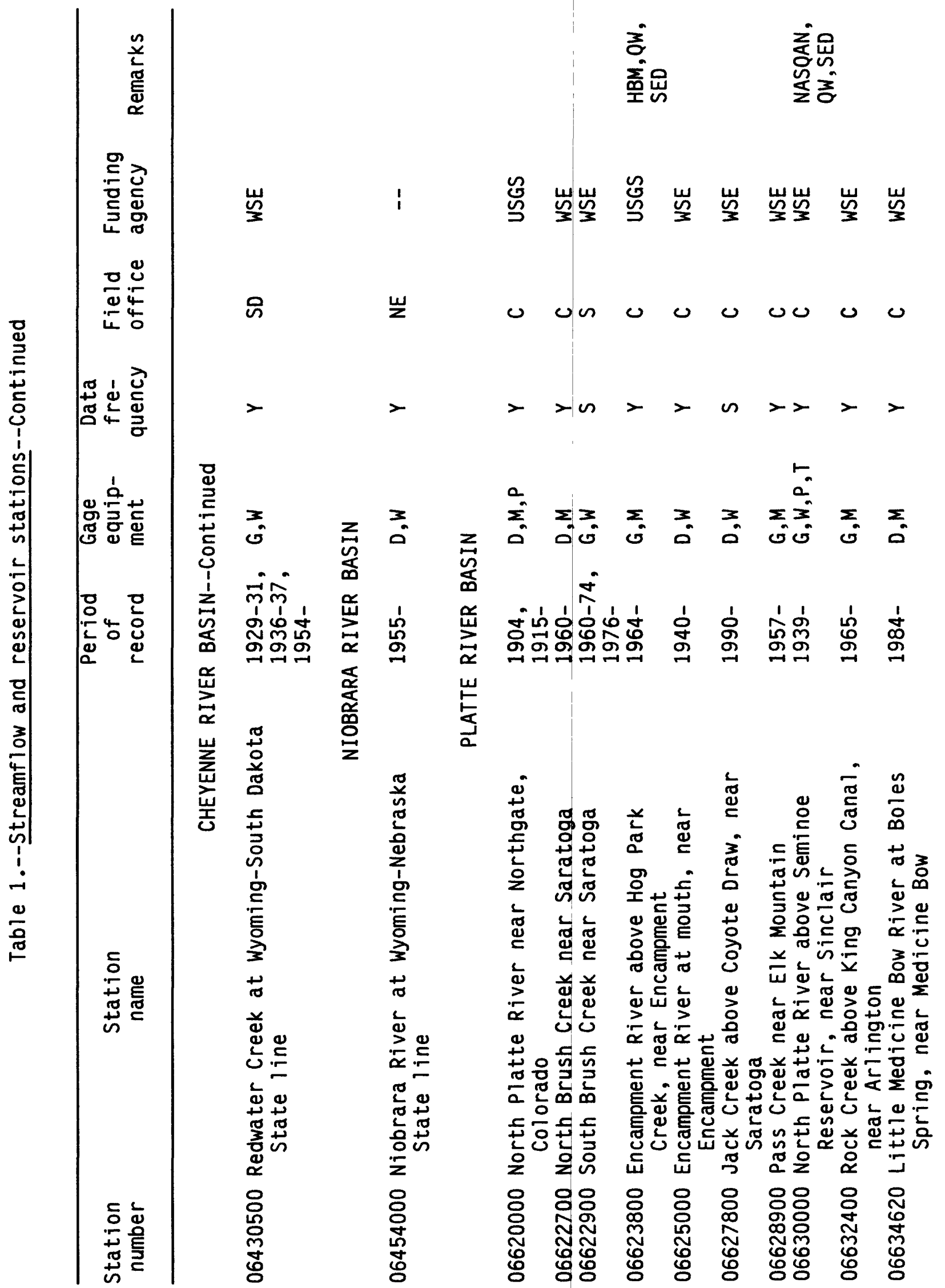




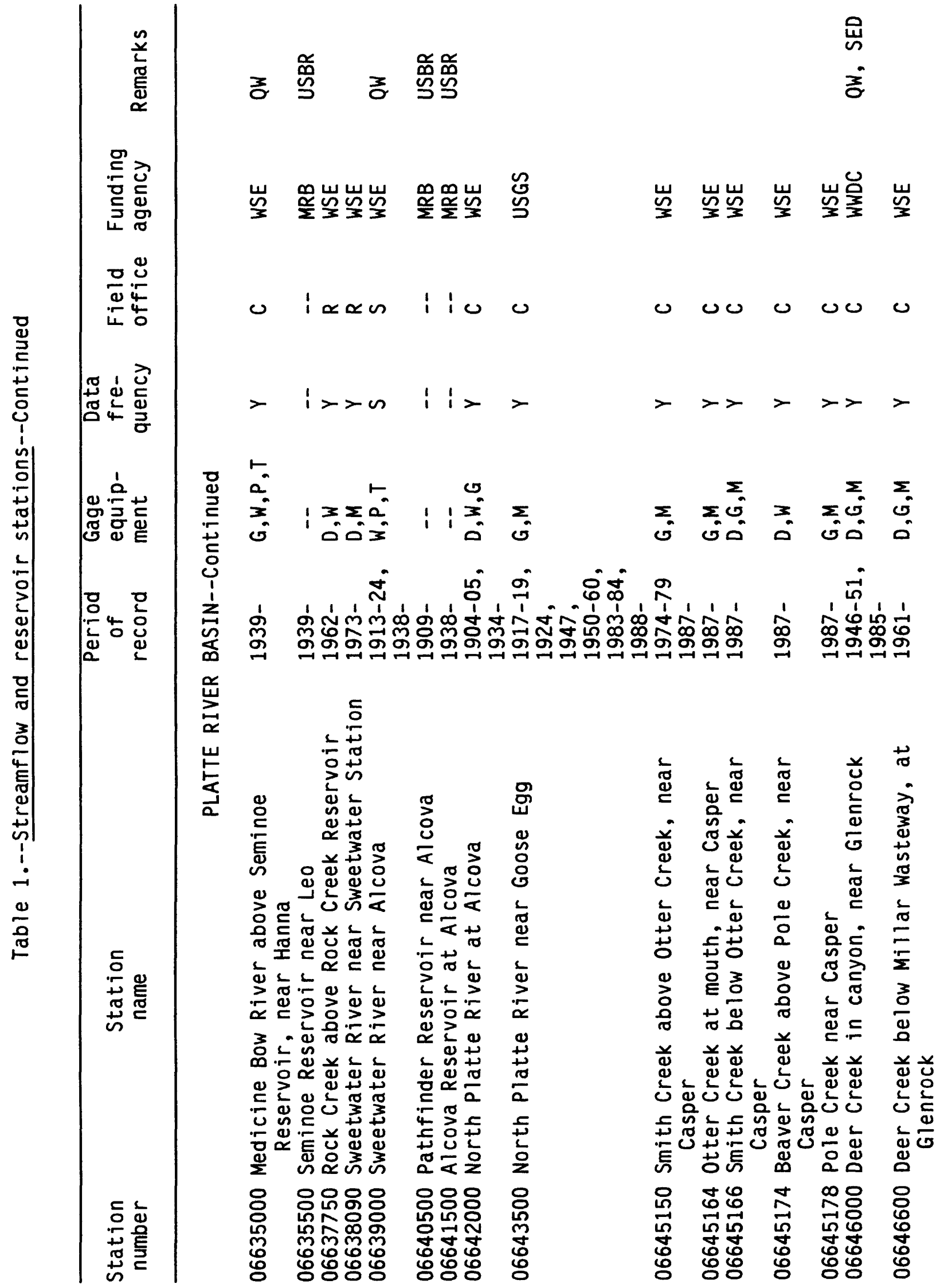




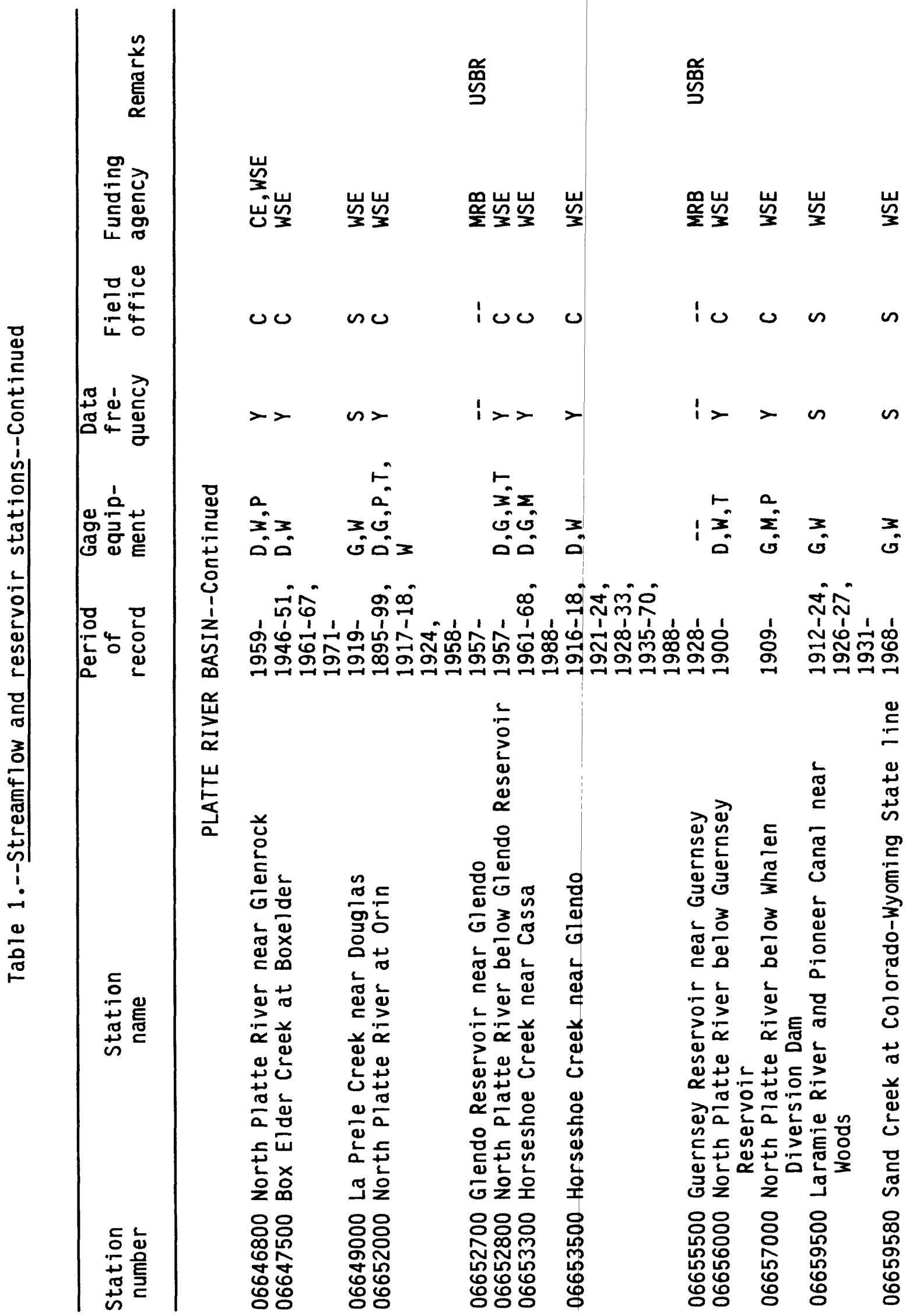




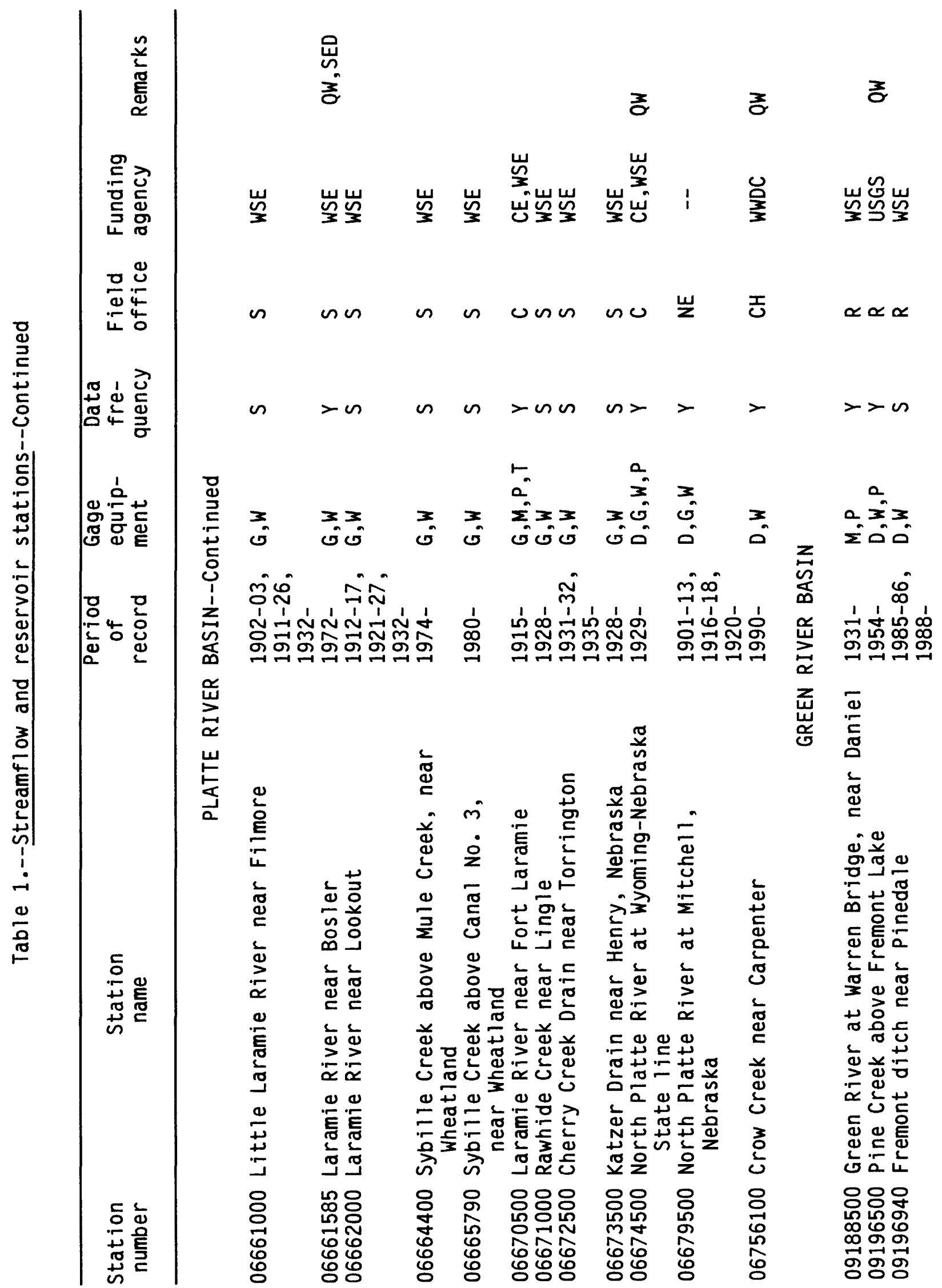




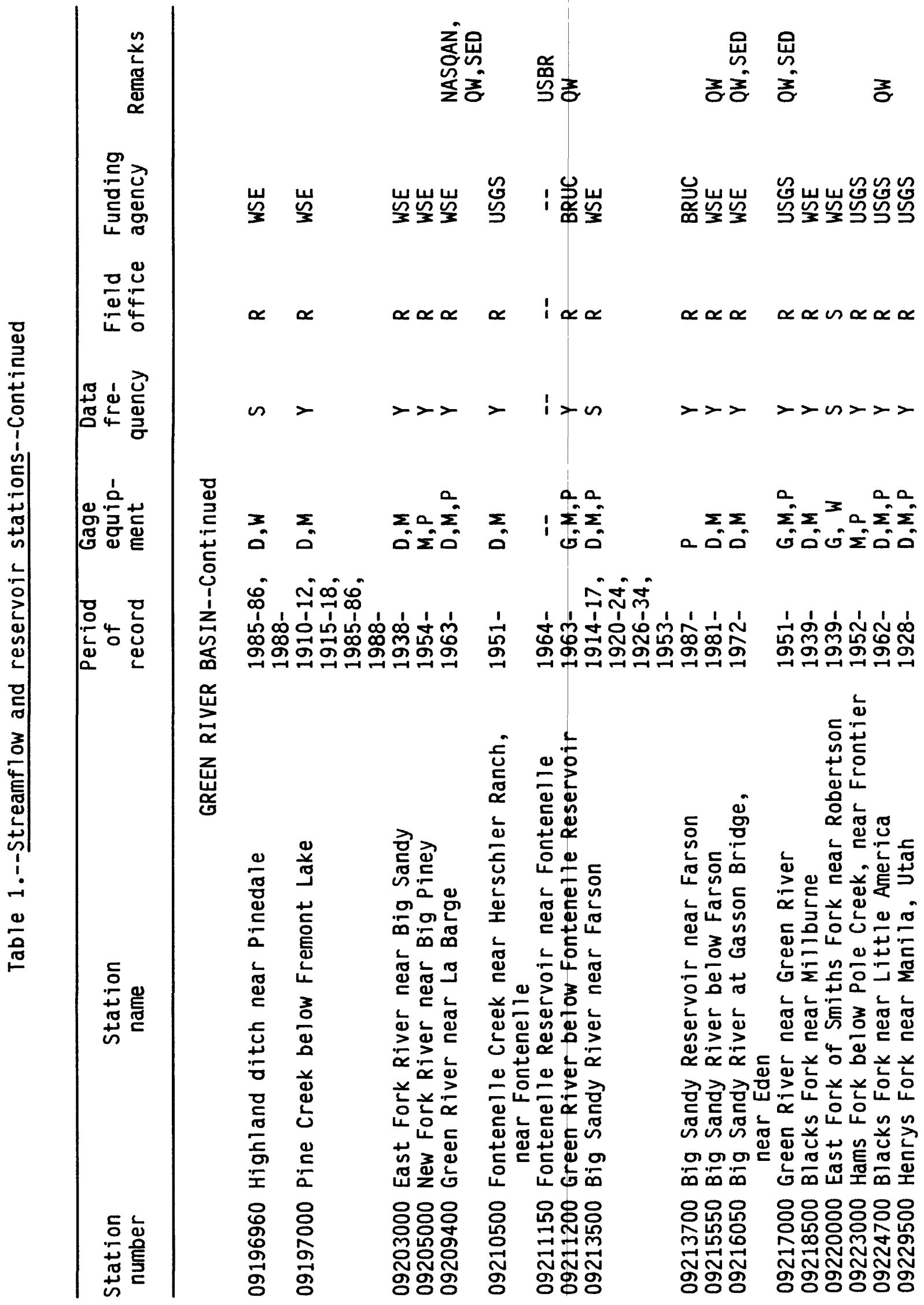




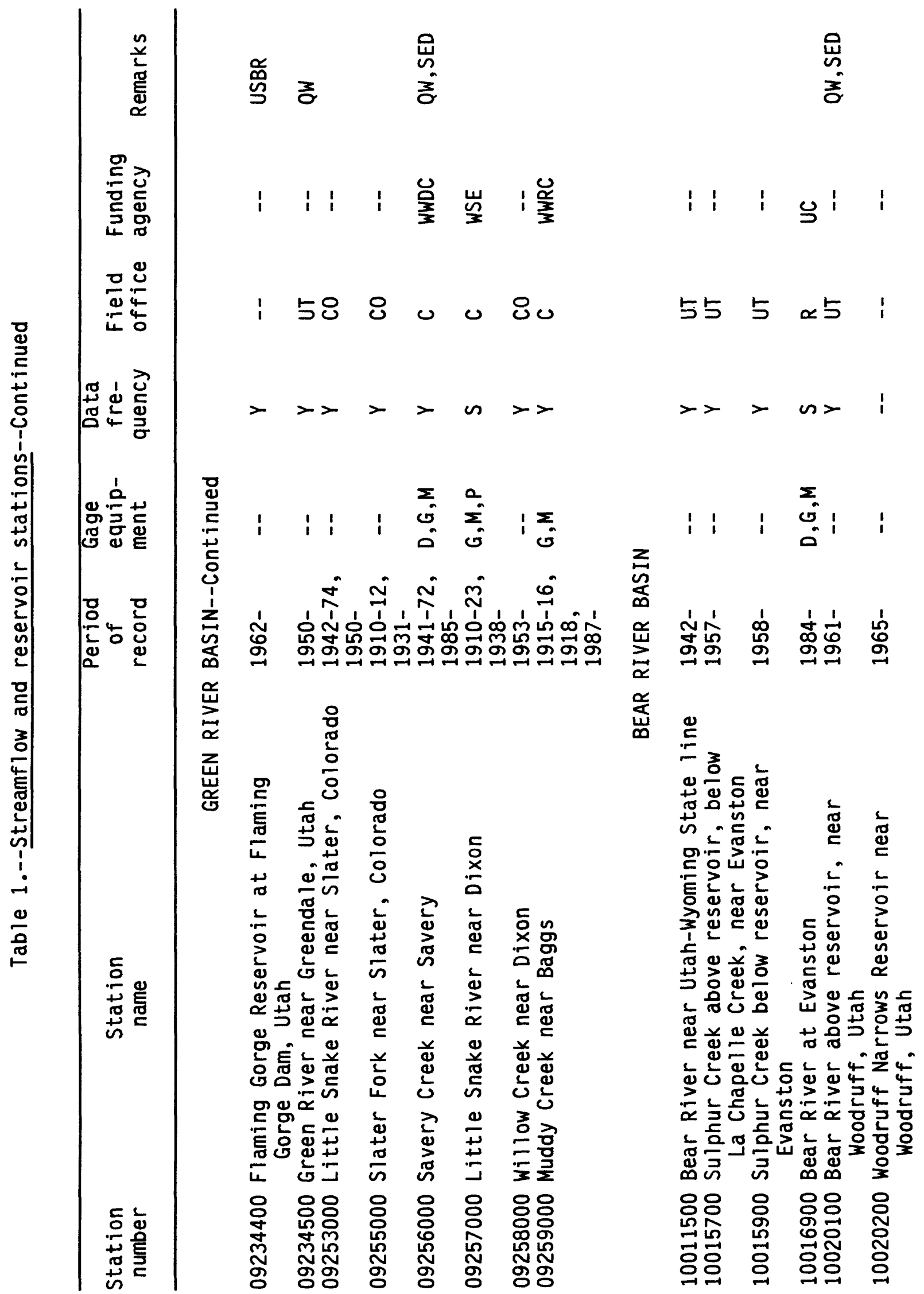




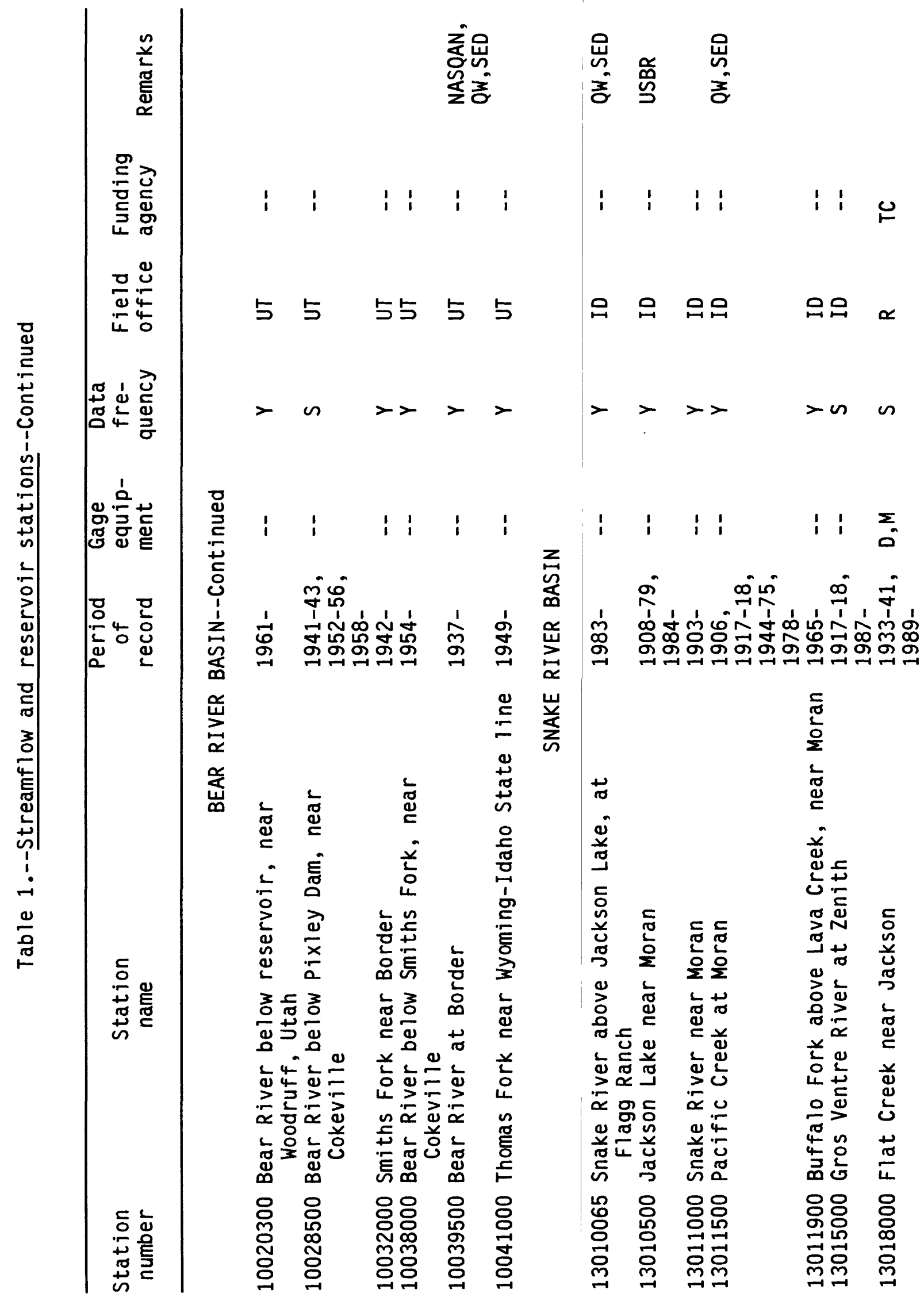




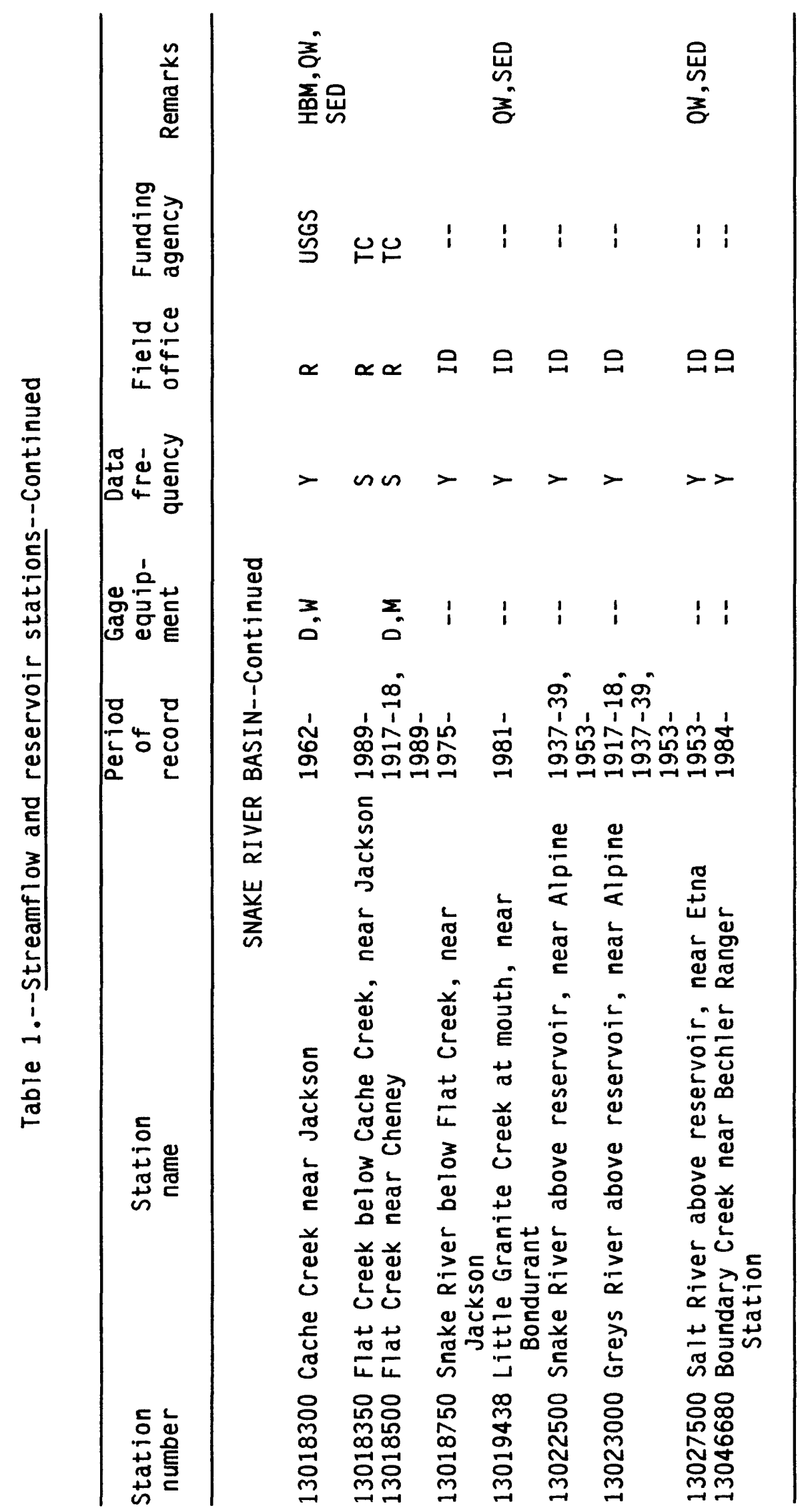


Table 2.--Surface-water-quality stations

Explanation of abbreviations and codes used in table 2

Period of record: The dates given are the calendar years in which records began or ended.

Data frequency:

BM bimonthly

C continuous (recorder)

D daily

HL high and low flow samples only

HML high flow, midsummer, low flow

L low flow

$M$ every six weeks plus two events

Q quarterly

$R$ rising, falling, peak stage, and low flow

SS sample during spraying season (frequency determined in late spring)

$T$ every 2 weeks during ice-free season

$W$ three during winter, monthly May-September

Analysis schedule:

1 salinity (major constituents)

2 specific conductance

3 daily temperature (observed or recorder)

4 suspended and dissolved organic carbon

5 field determinations of two or more: $\mathrm{pH}$, specific conductance, dissolved oxygen, temperature, or turbidity

6 fecal coliform, and (or) fecal streptococcus

7 nutrients

8 trace elements

9 pesticides

10 radiochemical

11 specific conductance and temperature (continuous monitors)

12 selenium

Field office:

C Casper

$\mathrm{CH}$ Cheyenne

ID Idaho District

MT Montana District

$R$ Riverton

UT Utah District

Funding agency:

BRUC Bureau of Reclamation, Colorado Region

GILL City of Gillette

MRB USGS, support for other Interior Agencies

USFS Forest Service

USGS U.S. Geological Survey, Federal Program

WDA Wyoming Department of Agriculture

WDEQ Wyoming Department of Environmental Quality

WRIR Wind River Indian Reservation, Northern Arapaho and Shoshone tribes 
WSE Wyoming State Engineer

WWDC Wyoming Water Development Commission

-- Not funded through Wyoming District

Remarks:

HBM hydrologic benchmark station

NASQAN national stream-quality accounting network station

SED also sediment station

SW also streamflow station 


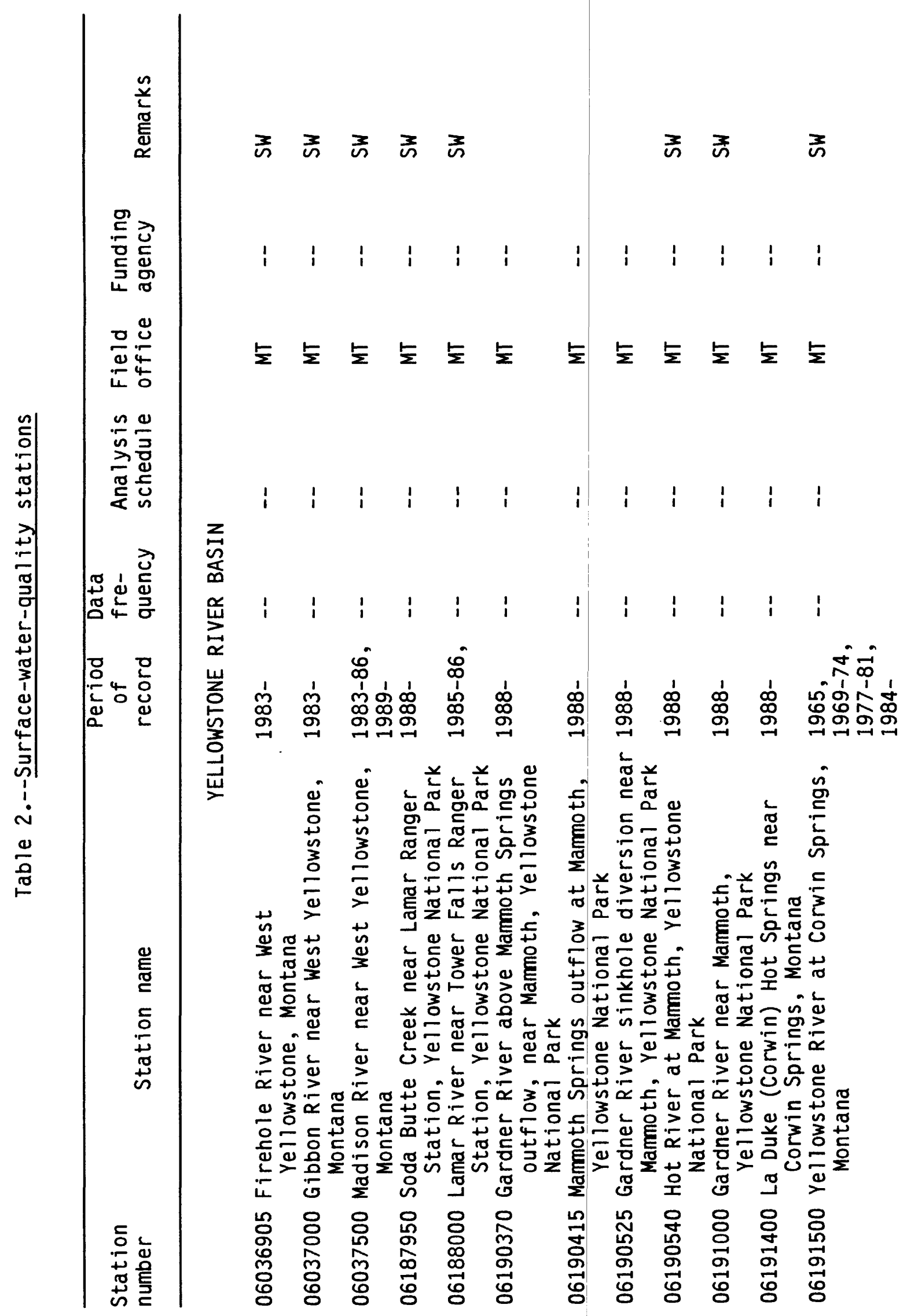




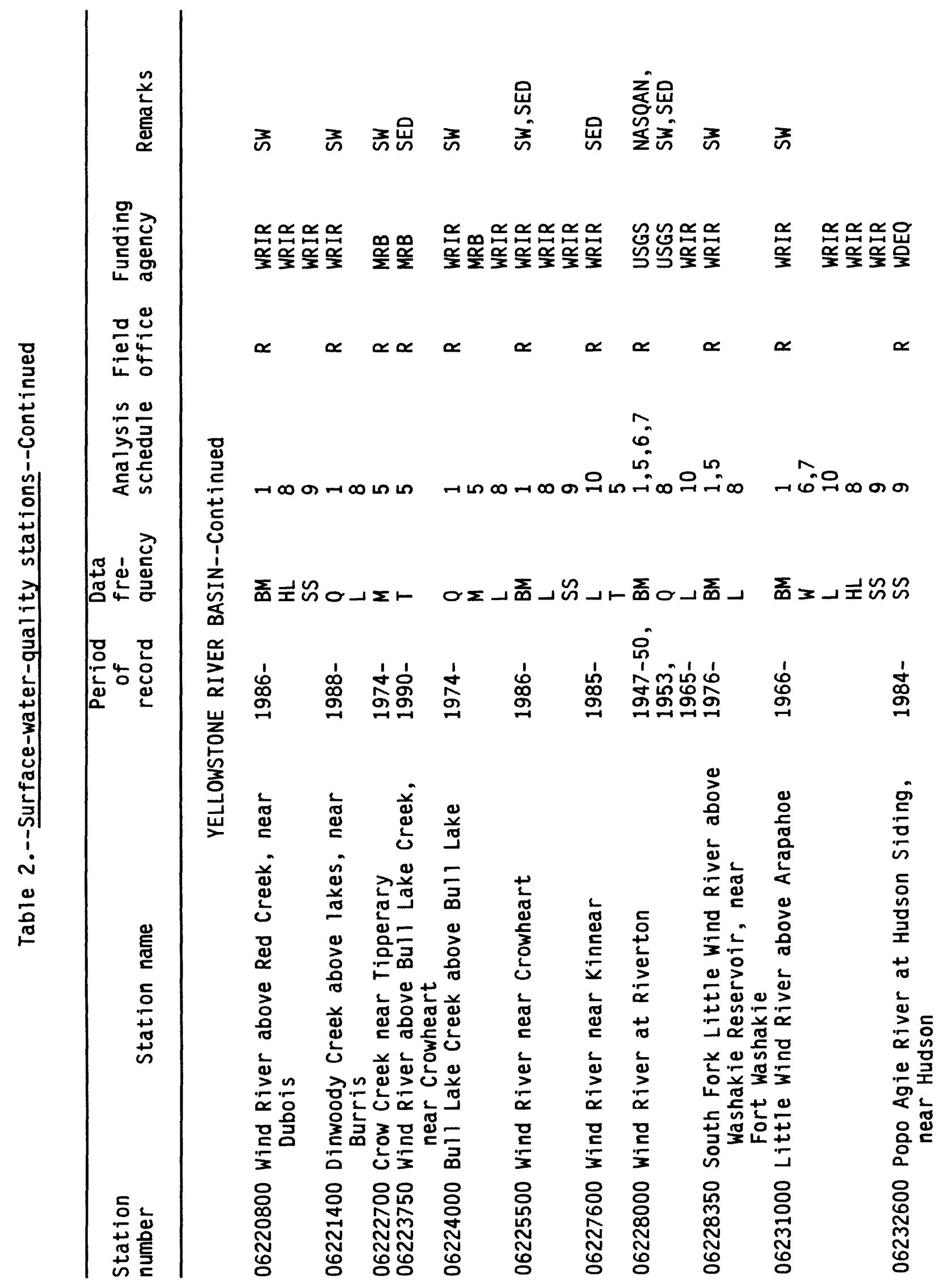




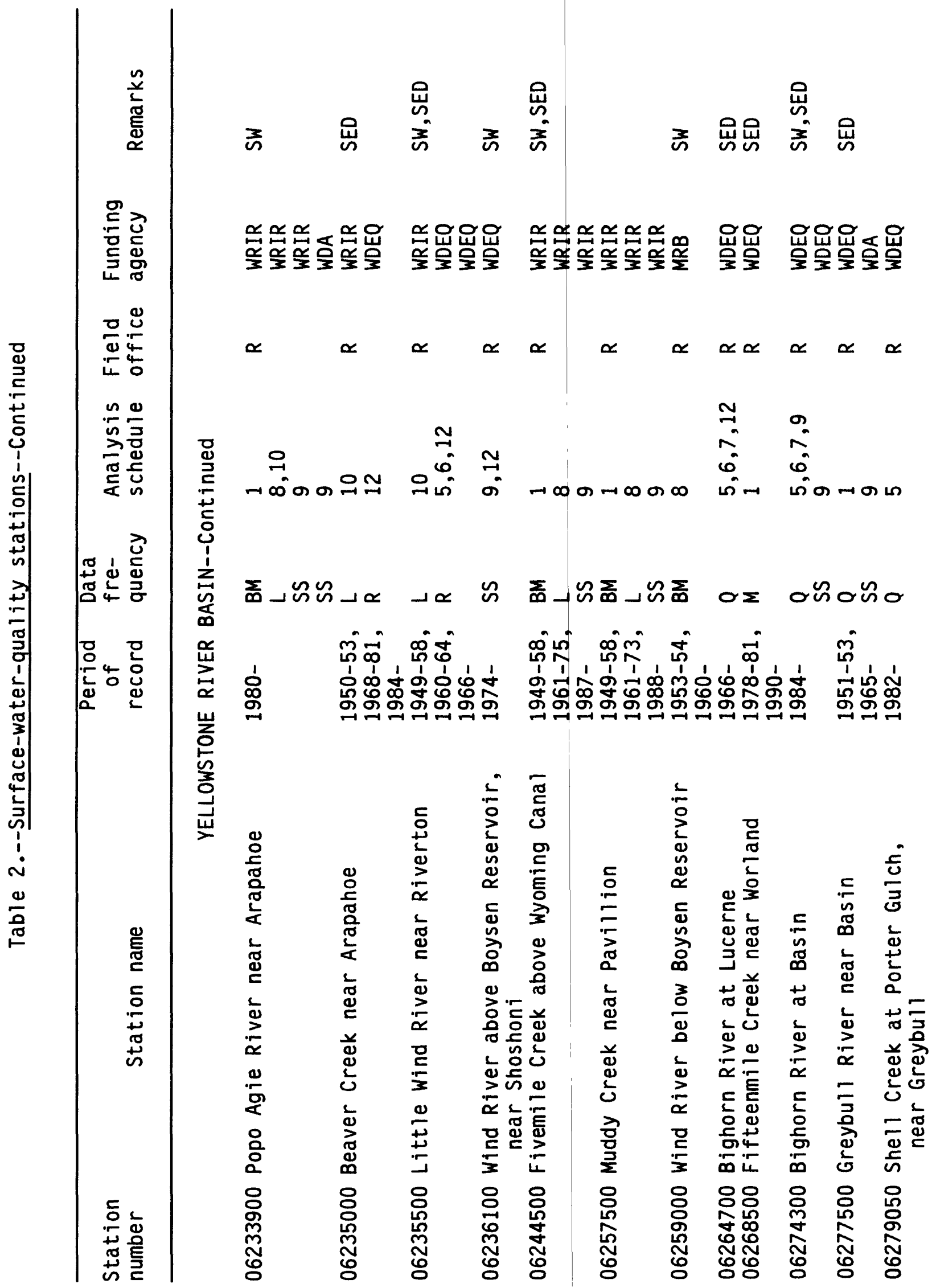




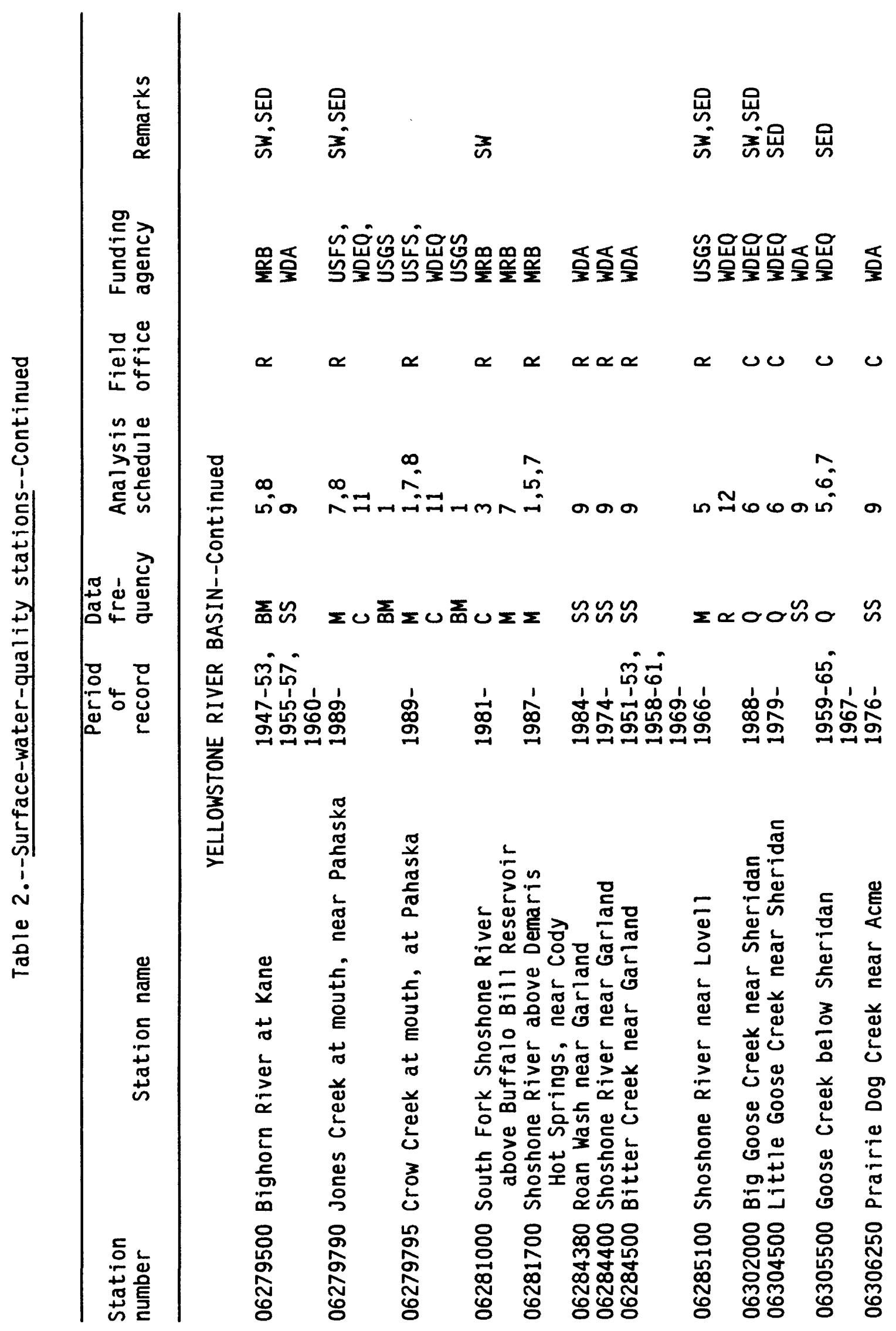




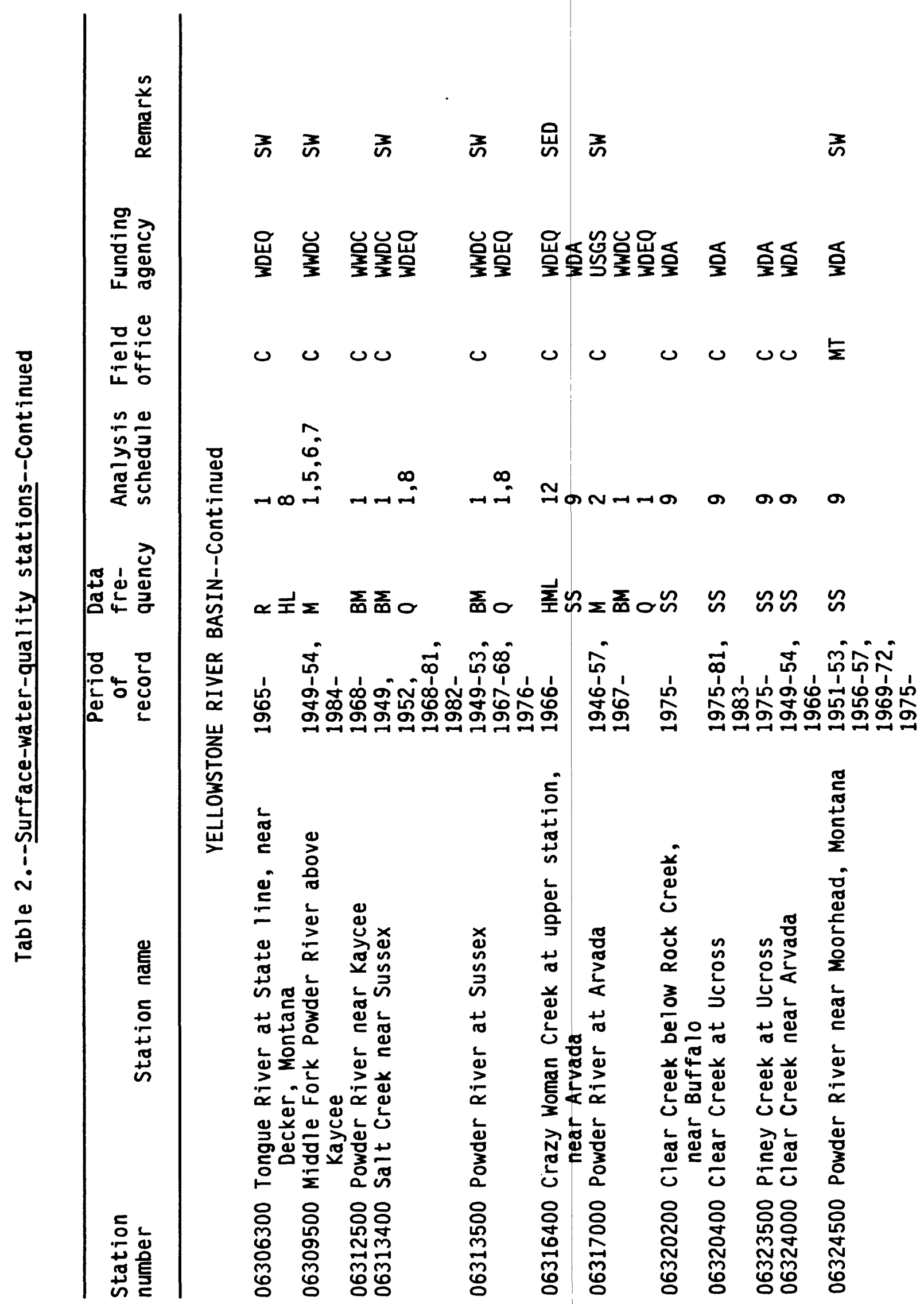




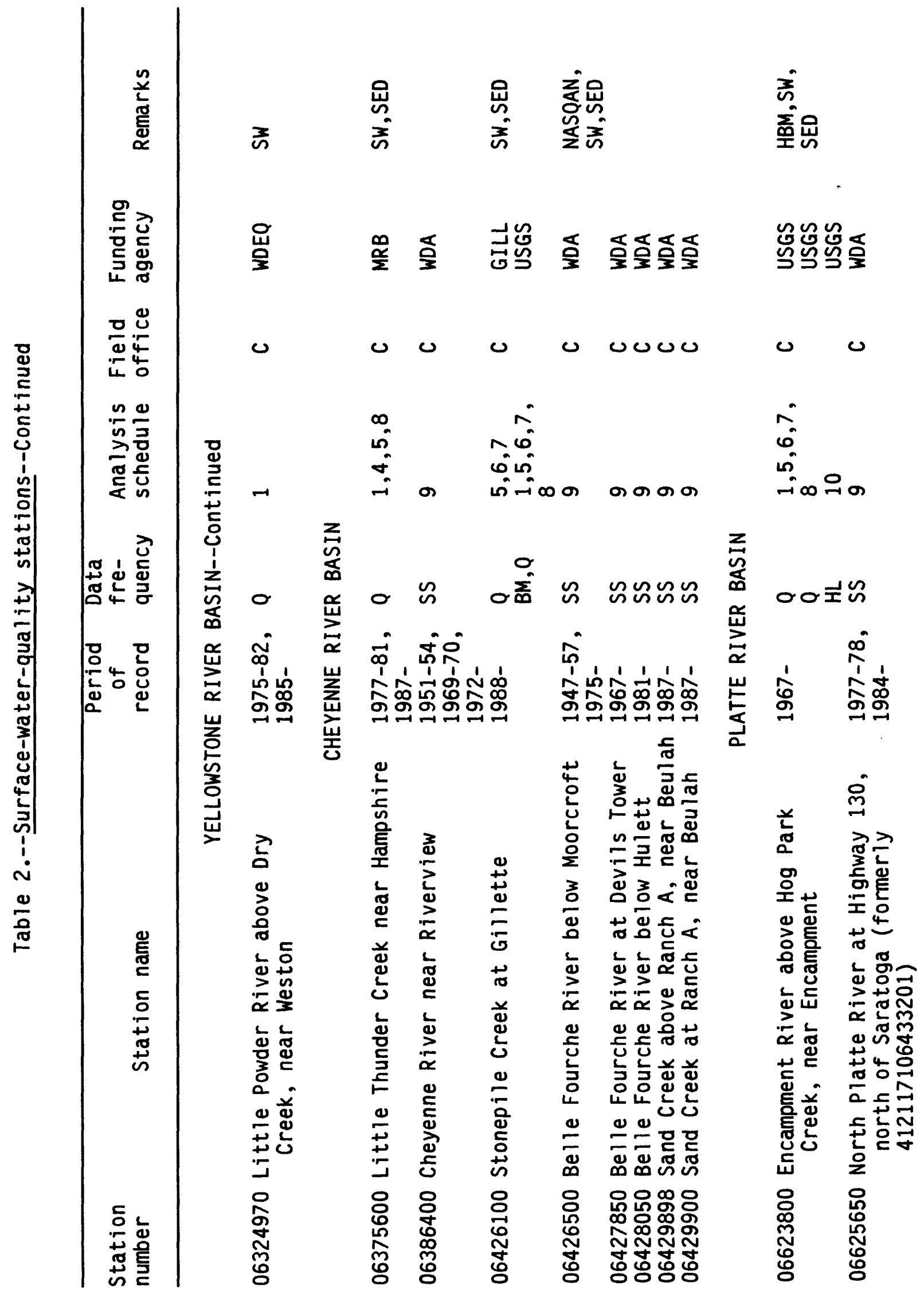




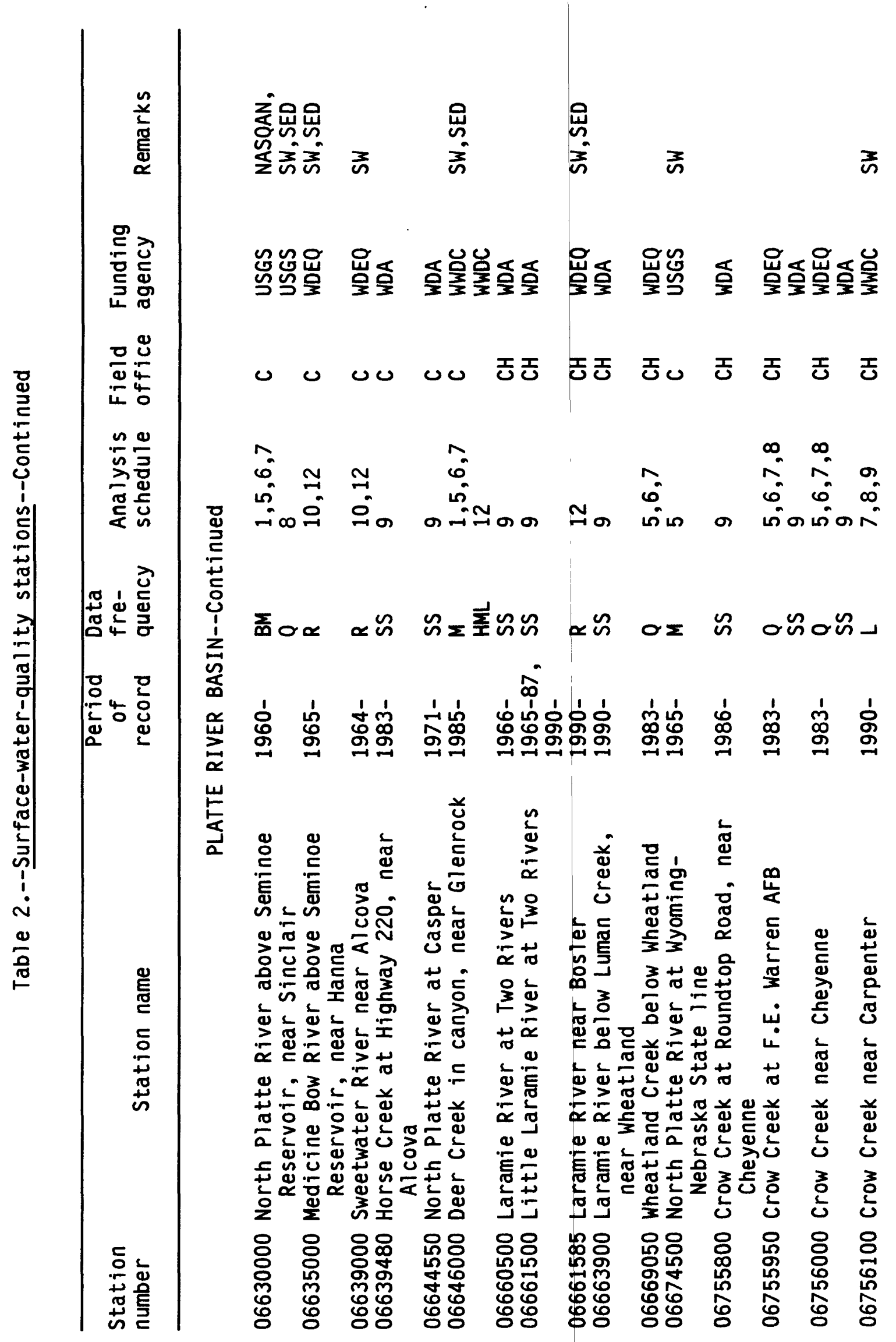




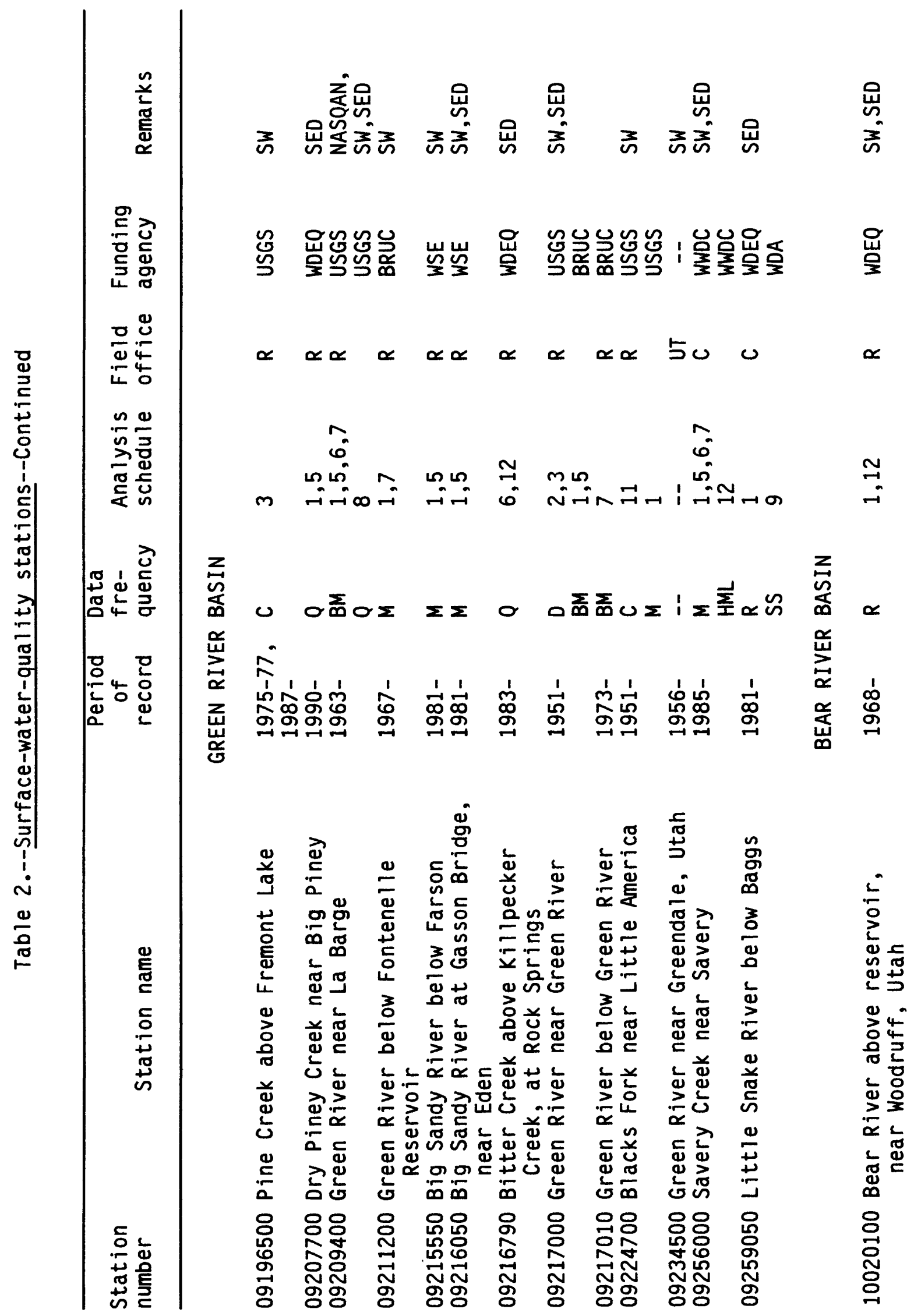




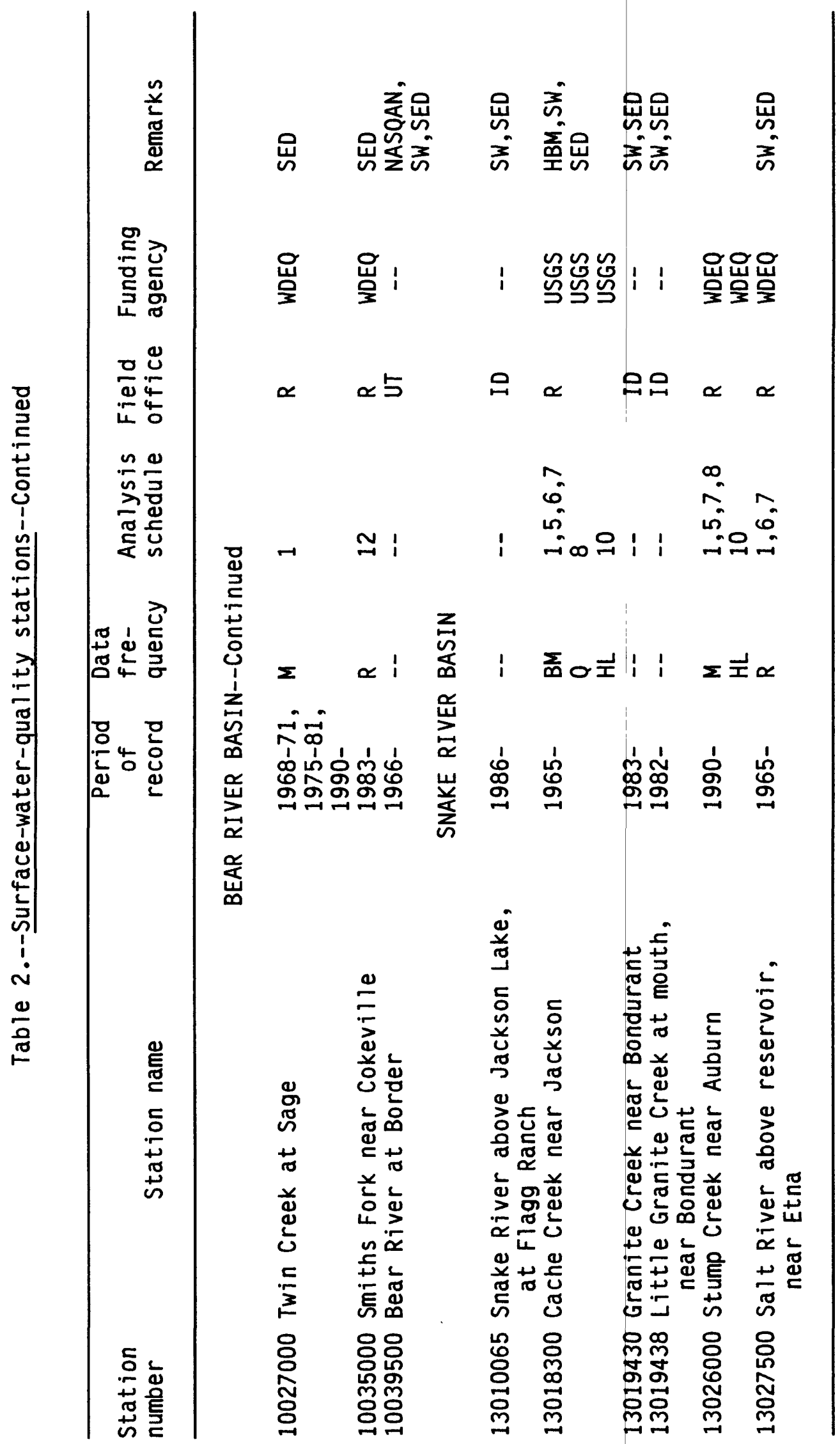


Table 3.--Sediment stations

Explanation of abbreviations and codes used in table 3

Period of record: The dates given are the calendar years in which records began or ended.

Data frequency:

BM bimonthly

D daily (observer)

HML high, medium, and low flow samples only

$I$ infrequent, whenever enough sediment in suspension to do analysis

$M$ every six weeks plus two events

$Q$ quarterly

$R$ rising, falling, peak stage, and low flow

$T$ every two weeks during ice-free season

Analysis schedule:

1 suspended-sediment concentration

2 particle-size distribution

3 0.062-millimeter sieve analysis

Field office:
C Casper
$\mathrm{CH}$ Cheyenne
ID Idaho District
$R$ Riverton
UT Utah District

Funding agency:

GILL City of Gillette

MRB USGS, support for other Interior Agencies

USFS Forest Service

USGS U.S. Geological Survey, Federal Program

WDEQ Wyoming Department of Environmental Quality

WWDC Wyoming Water Development Commission

Remarks:

HBM hydrologic benchmark station

NASQAN national stream-quality accounting network station

QW also water-quality station

SW also streamflow station

WWRC Record furnished by Wyoming Water Research Center 


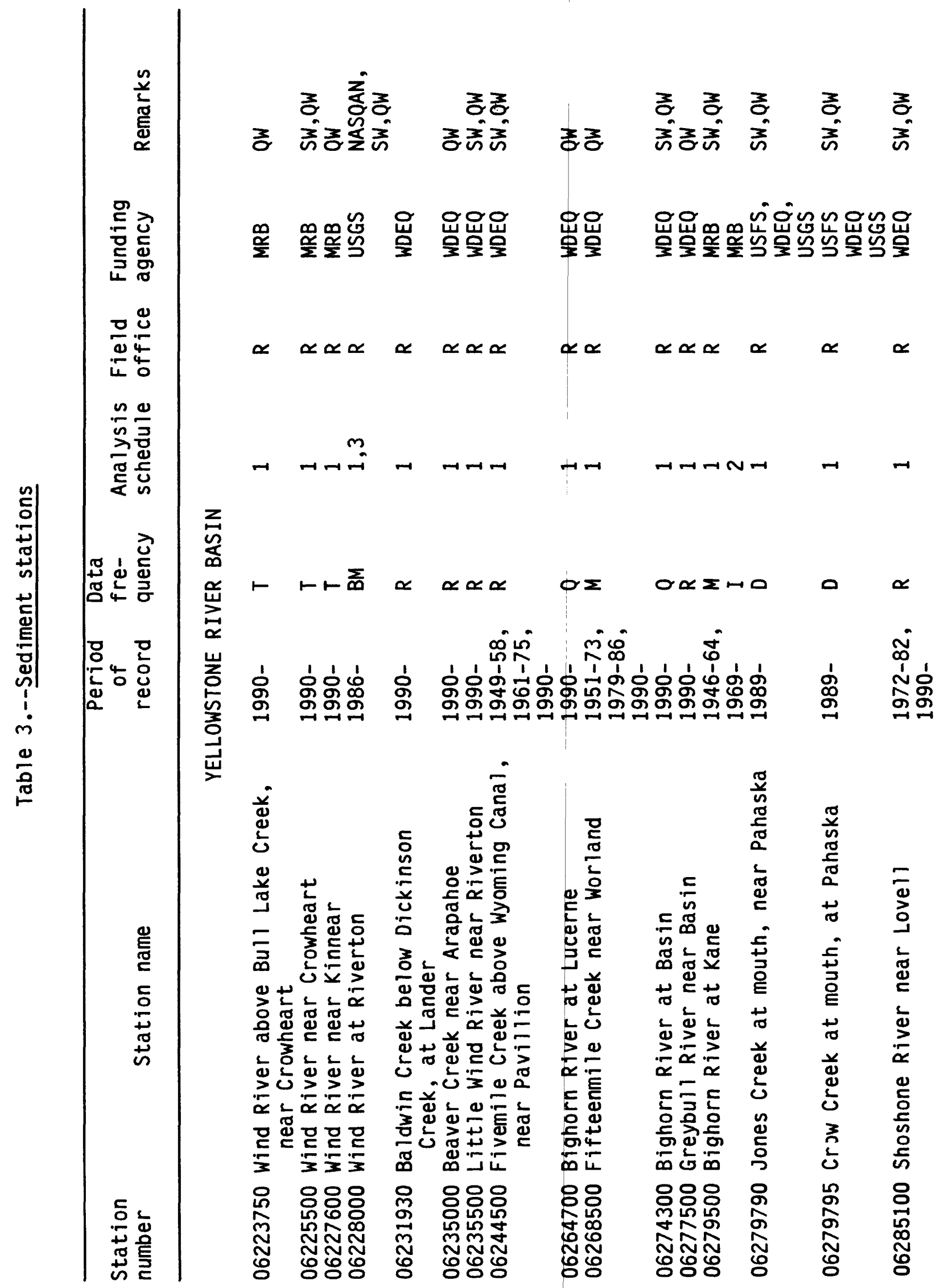




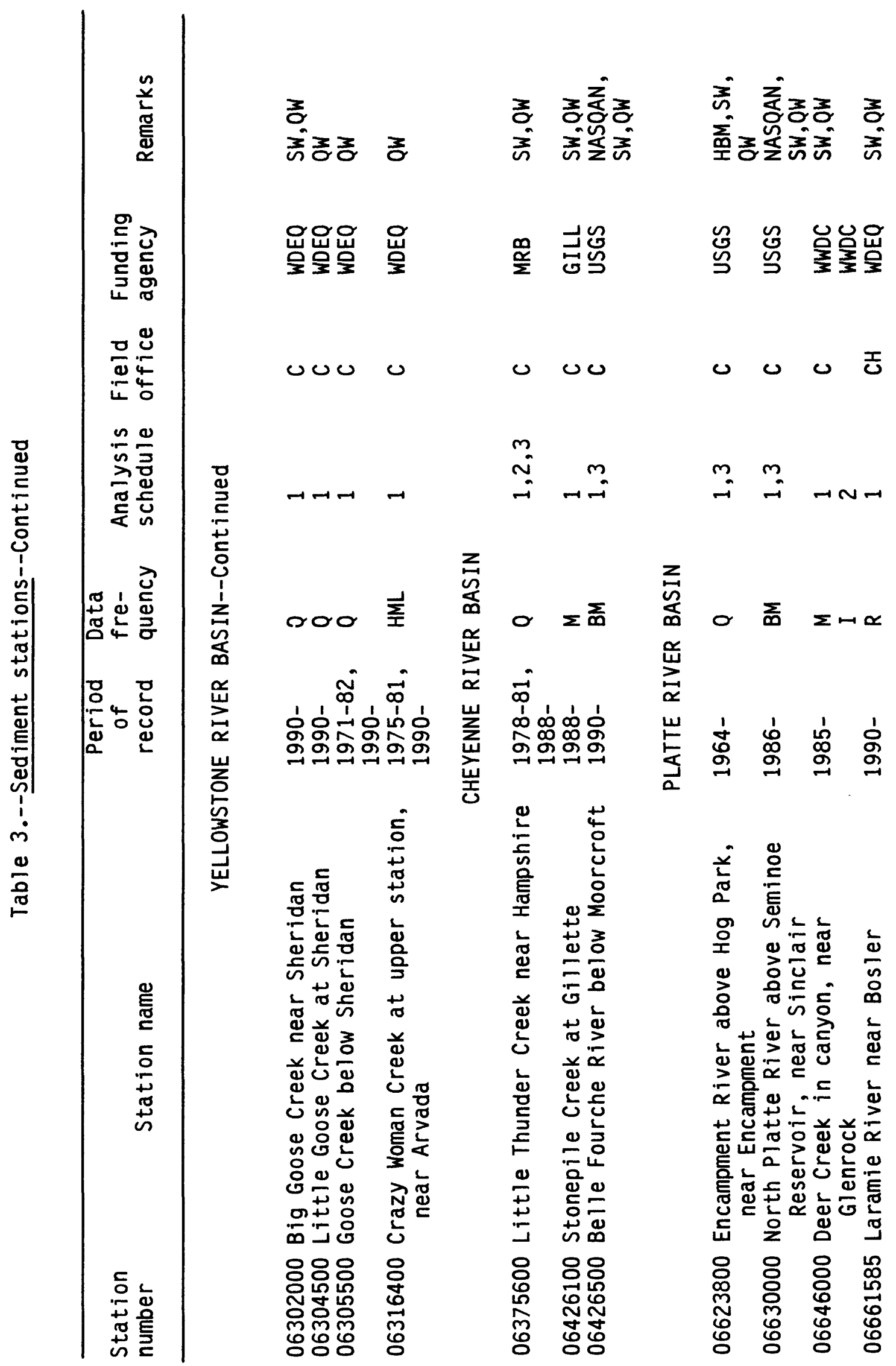




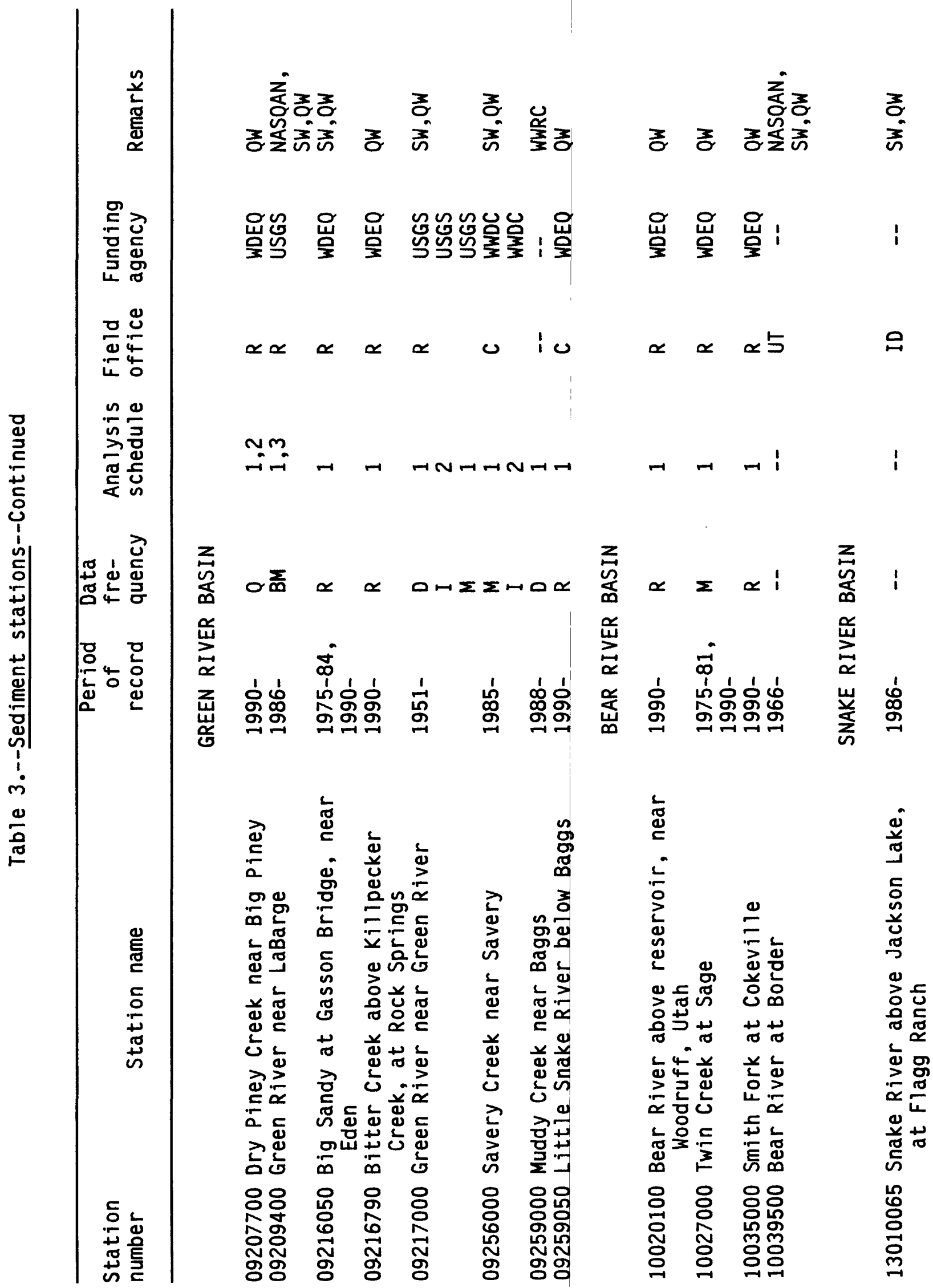




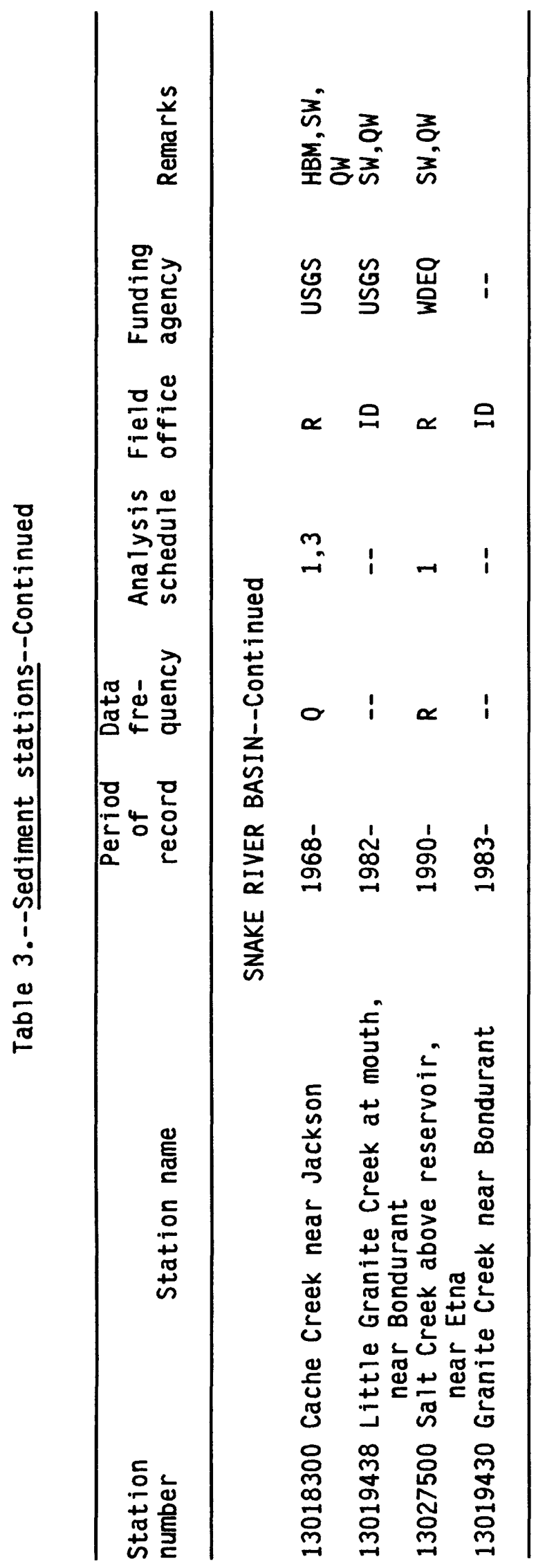


Table 4.--Ground-water-level observation wells

\section{Explanation of abbreviations and codes used in table 4}

Site number: Sequential number (by county) used to show location of well in figure 5 .

Local well number: The locations of most wells in this report are based on the Federal system of land subdivision. The first number denotes the township north of the 40th Parallel Base Line, the second number denotes the range west of the Sixth Principal Meridian, and the third number denotes the section. A section is divided into quarters of 160 acres each; each quarter is designated $a, b, c$, or $d$ in a counterclockwise direction, beginning in the northeast quarter. Each quarter is divided into quarters of 40 acres each and aga in into quarters (10-acre tracts). Alphabetical designations also are assigned to the subsequent subdivisions. A numeral appearing after the letters distinguishes that well from other numbered wells within the same 10-acre tract. The following illustration shows the location of well 12-060-07ddd01 in Laramie County:

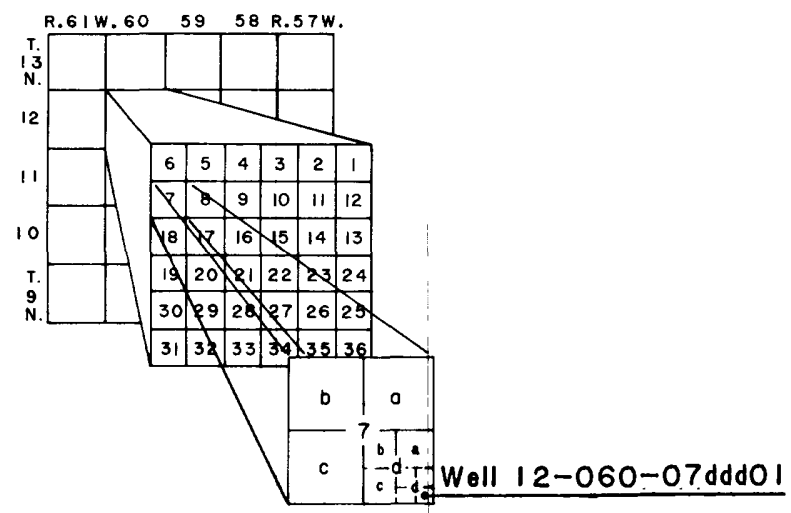

Observation wells on the Wind River Indian Reservation and adjacent area in Fremont County are located similarly; however, they are in a land subdivision that is referenced as the Wind River Base Line and Meridian. The uppercase letter that begins the number designates the quadrant of the system. The quadrants are lettered A, B, C, and D in a counterclockwise direction beginning with $A$ in the northeast quadrant. Otherwise, the well numbers are the same as in the preceding paragraph:

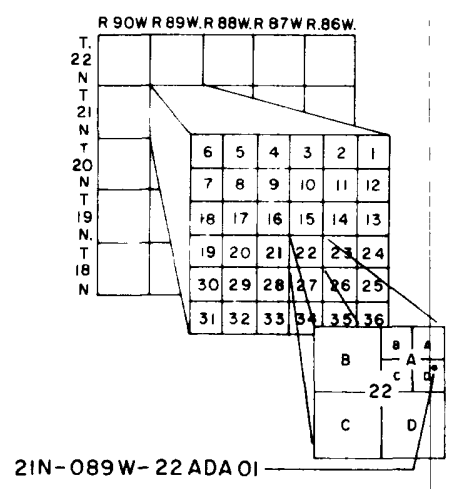


Explanation of abbreviations and codes used in table 4--Continued

Period of record: The dates given are the calendar years in which records began or ended. A record consists of one or more measurements during a calendar year.

Geologic source code: The following codes have been retrieved from the water Data Storage and Retrieval System (WATSTORE) of the USGS and may not follow the current usage of the Survey.

\begin{tabular}{|c|c|c|c|c|}
\hline Erathem & System & Series & $\begin{array}{l}\text { Geologic } \\
\text { source code }\end{array}$ & $\begin{array}{c}\text { Formation } \\
\text { name }\end{array}$ \\
\hline \multirow[t]{7}{*}{ Cenozoic } & Quaternary & Holocene & $\begin{array}{l}\text { ALVM } \\
\text { TRRC } \\
\end{array}$ & $\begin{array}{l}\text { Alluvium } \\
\text { Terrace deposits }\end{array}$ \\
\hline & \multirow[t]{6}{*}{ Tertiary } & $\begin{array}{l}\text { Pliocene and } \\
\text { Miocene }\end{array}$ & NRPK & North Park Formation \\
\hline & & Miocene & $\begin{array}{l}\text { OGLL } \\
\text { ARKR }\end{array}$ & $\begin{array}{l}\text { Ogallala Formation } \\
\text { Arikaree Formation }\end{array}$ \\
\hline & & oligocene & $\begin{array}{l}\text { BRUL } \\
\text { WRVR }\end{array}$ & $\begin{array}{l}\text { Brule Formation } \\
\text { White River Formation } \\
\text { or Group }\end{array}$ \\
\hline & & Eocene & WDRV & Wind River Formation \\
\hline & & $\begin{array}{l}\text { Eocene and } \\
\text { Paleocene } \\
\end{array}$ & WSTC & Wasatch Formation \\
\hline & & Paleocene & LEBO & $\begin{array}{l}\text { Lebo Member of Fort } \\
\text { Union Formation }\end{array}$ \\
\hline \multirow[t]{2}{*}{ Mesozoic } & \multirow[t]{2}{*}{ Cretaceous } & Upper Cretaceous & FXHL & Fox Hills Sandstone \\
\hline & & Lower Cretaceous & LKOT & Lakota Formation \\
\hline \multirow[t]{7}{*}{ Paleozoic } & \multirow[t]{4}{*}{ Permian } & $\begin{array}{l}\text { Upper and Lower } \\
\text { Permian }\end{array}$ & PRKC & Park City Formation \\
\hline & & $\begin{array}{l}\text { Lower Permian, } \\
\text { Upper and Middle } \\
\text { Pennsylvanian }\end{array}$ & CSPR & Casper Formation \\
\hline & & $\begin{array}{l}\text { Lower Permian and } \\
\text { Pennsylvanian }\end{array}$ & MNLS & Minnelusa Formation \\
\hline & & $\begin{array}{l}\text { Lower Permian, } \\
\text { Upper and Middle } \\
\text { Pennsylvanian }\end{array}$ & TSLP & Tensleep Sandstone \\
\hline & \multirow[t]{2}{*}{ Mississippian } & $\begin{array}{l}\text { Upper and Lower } \\
\text { Mississippian }\end{array}$ & MDSN & Madison Limestone \\
\hline & & Lower Mississippian & PHSP & Pahasapa Limestone \\
\hline & Cambrian & Middle Cambrian & FLTD & Flathead Sandstone \\
\hline
\end{tabular}


Data frequency:

$C$ continuous (graphic or digital recorder)

$M$ monthly (12 visits per year)

Field office:

C Casper

$\mathrm{CH}$ Cheyenne Hydrologic

Surveillance Section

P Project Personnel

$R$ Riverton

$S$ Wyoming State Engineer

Funding agency:

SE Wyoming State Engineer with support from Wyoming Economic Development and Stabilization Board

USGS U.S. Geological Survey, Federal Program

Local name: Indicates a reference name of the well 


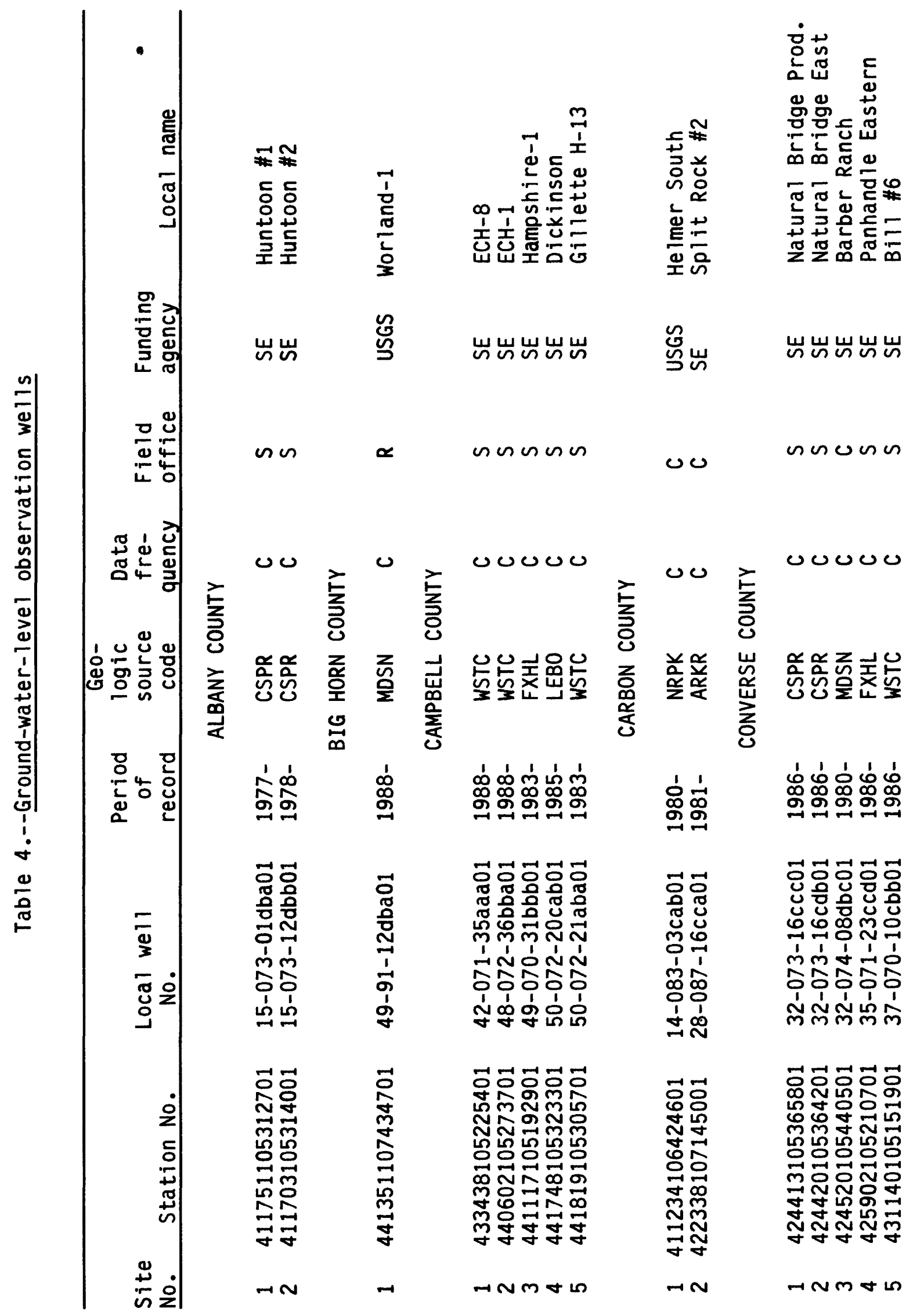




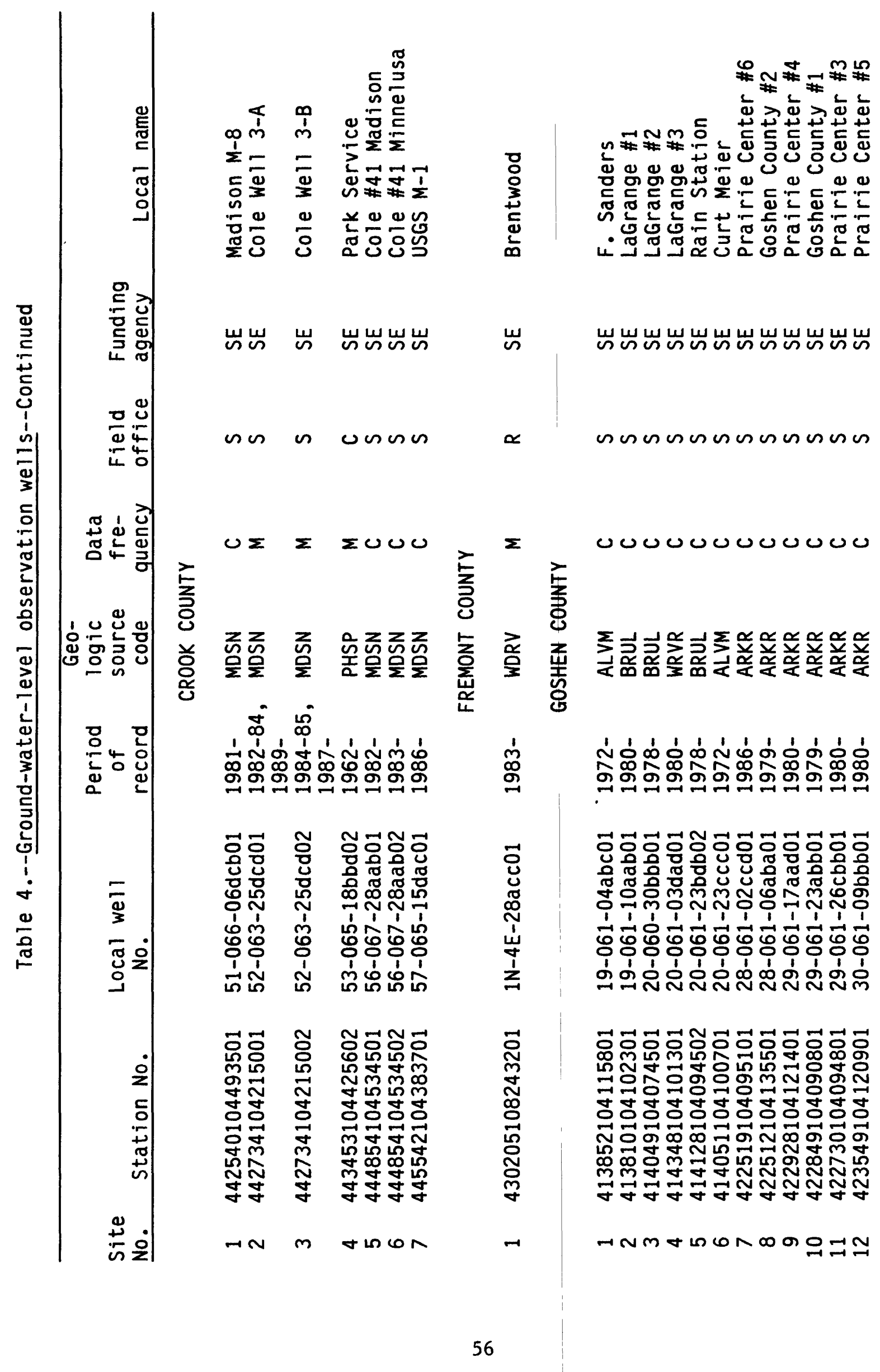




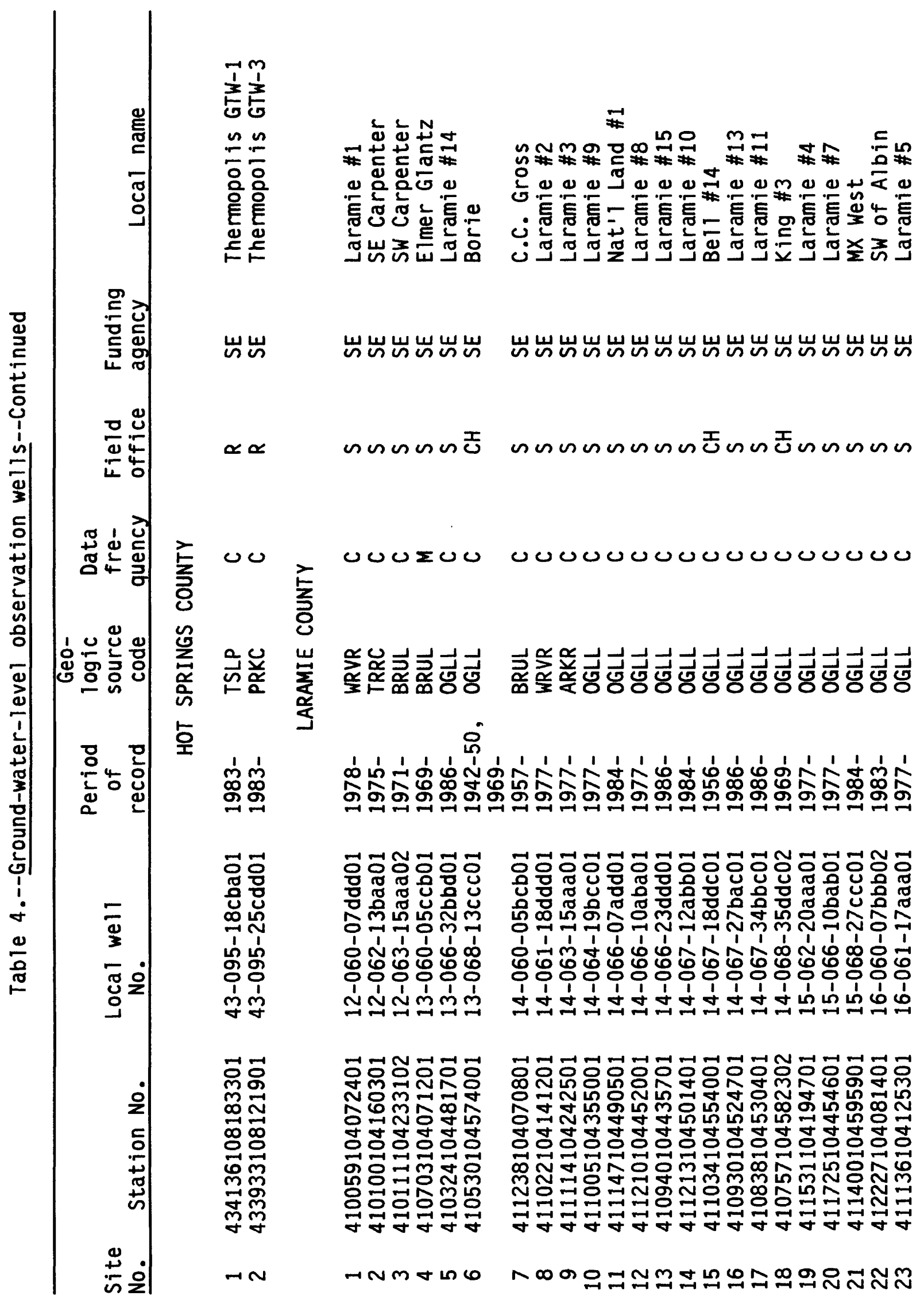




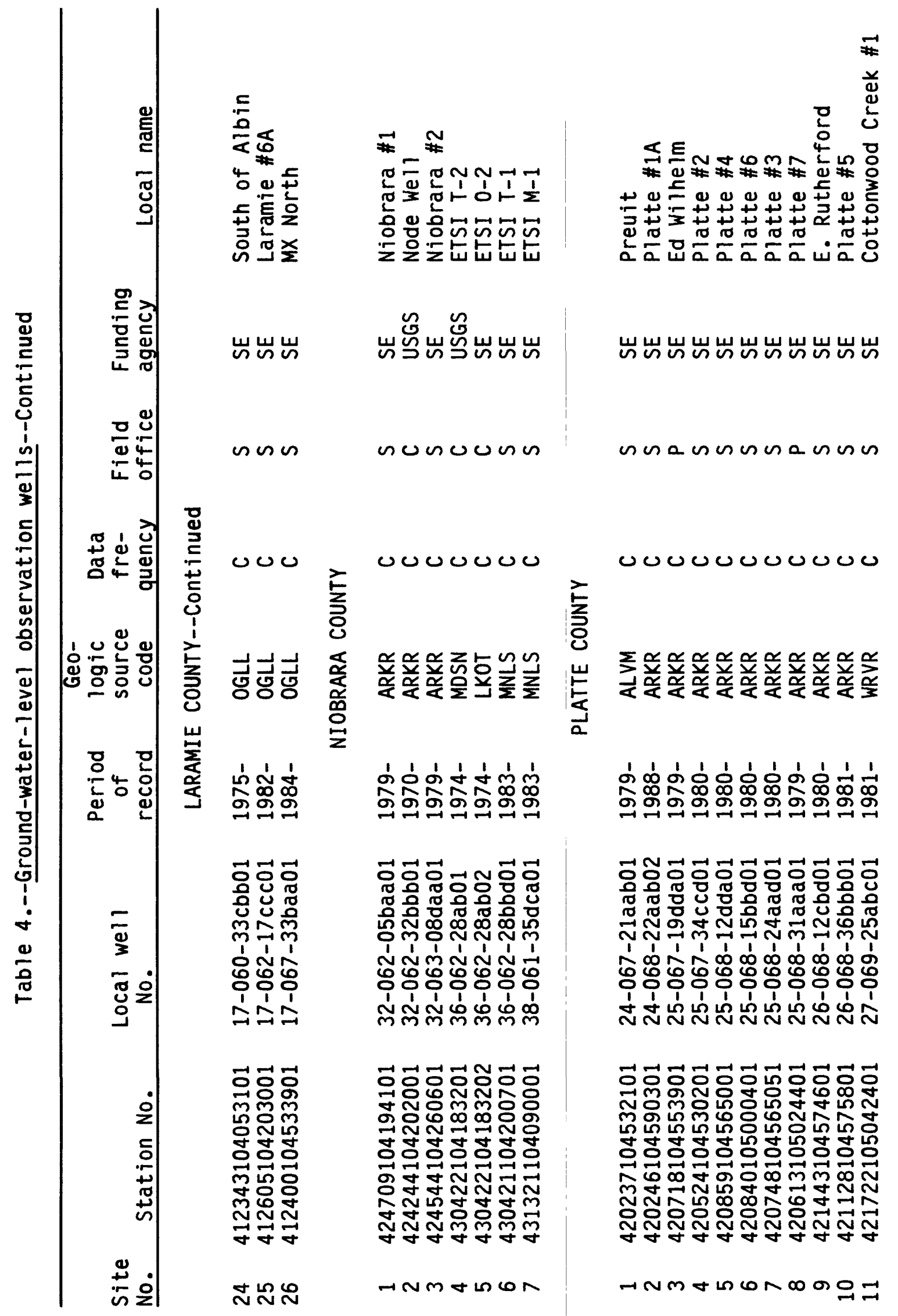




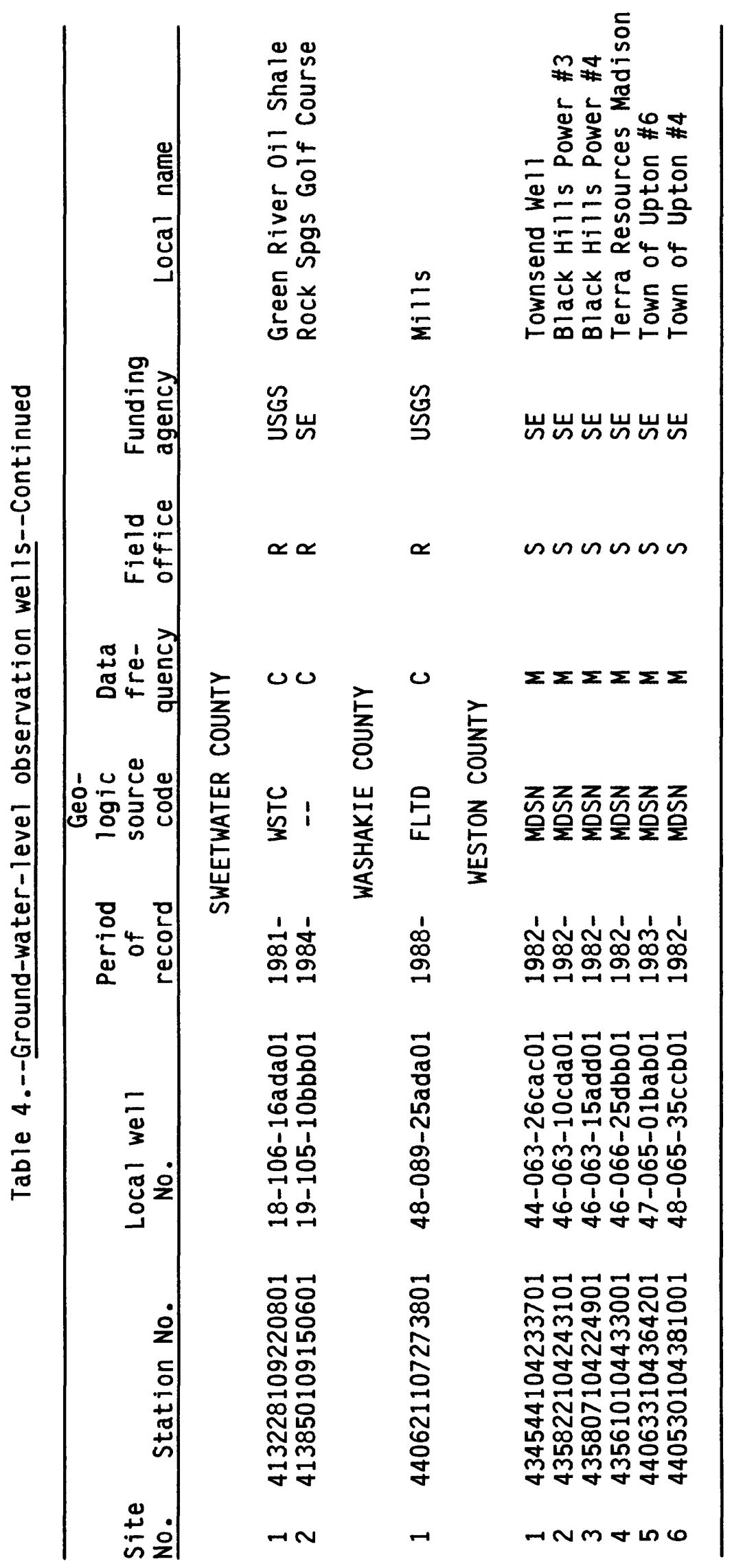


Table 5.--Ground-water-quality sites

\section{Explanation of abbreviations and codes used in table 5}

Site number: Sequential number (by county) used to show location of well in figure 6 .

Station number: Station identification number which consists of latitude, longitude, and a two-digit sequence number.

Local well number: The locations of most wells in this report are based on the Federal system of land subdivision. The first number denotes the township north of the 40th Parallel Base Line, the second number denotes the range west of the Sixth Principal Meridian, and the third number denotes the section. A section is divided into quarters of 160 acres each; each quarter is designated $a, b, c$, or $d$ in a counterclockwise direction, beginning in the northeast quarter. Each quarter is divided into quarters of 40 acres each and aga in into quarters (10-acre tracts). Alphabetical designations also are assigned to the subsequent subdivisions. A numeral appearing after the letters distinguishes that well from other numbered wells within the same 10-acre tract. The following 1llustration shows the location of well 12-060-07ddd01 in Laramie County:

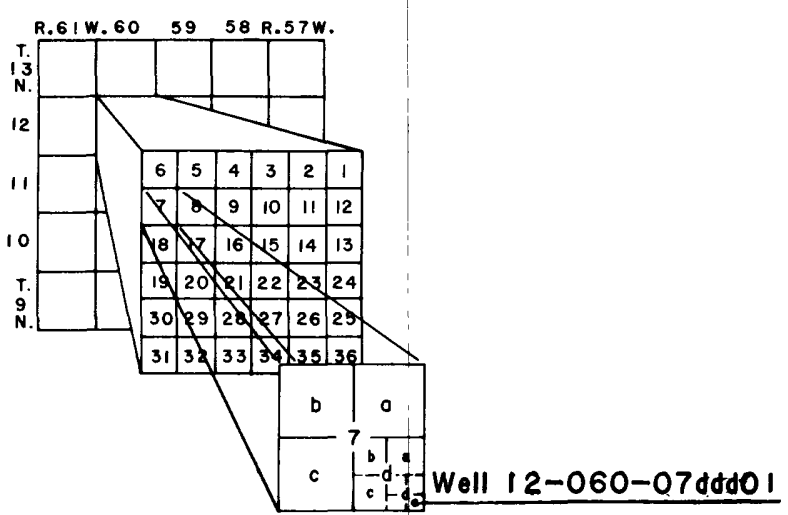

Observation wells on the Wind River Indian Reservation and adjacent area in Fremont County are located similarly; however, they are in a land subdivision that is referenced as the Wind River Base Line and Meridian. The uppercase letter that begins the number designates the quadrant of the system. The quadrants are numbered $A, B, C$, and $D$ in a counterclockwise direction beginning with $A$ in the northeast quadrant. Otherwise, the well numbers are the same as given in the preceding paragraph.

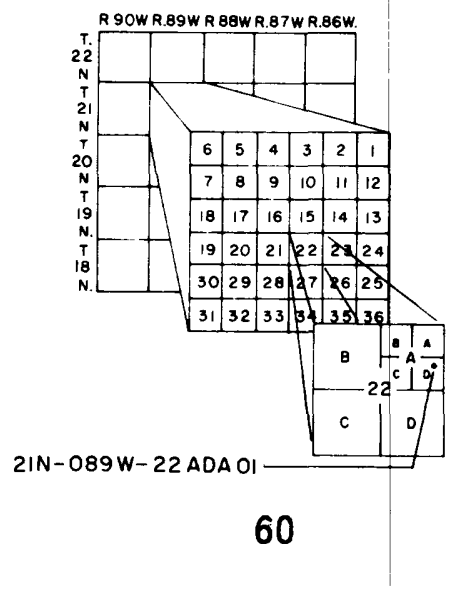


Analysis schedule:

1 major dissolved ions (salinity)

2 herbicides

Note--The statewide ground-water-quality reconnaissance network is operated in cooperation with the Wyoming Department of Agriculture. The sampling design is based on division of the State into four quarters, with a different quarter of the State sampled each year. Within the selected quadrant, approximately 25 active well s in irrigated areas are selected for sampling. Personnel from the Cheyenne office have collected at least one sample per well, although some wells have been resampled as noted in the table. 
Table 5.--Ground-water-quality sites

\begin{tabular}{ll}
$\begin{array}{l}\text { Site } \\
\text { num- } \\
\text { ber }\end{array}$ & Station number \\
\hline & \\
1 & 412857105380401 \\
& \\
& \\
1 & 441449107464801 \\
2 & 441514107580801 \\
3 & 441726108004901 \\
4 & 442346108135701 \\
5 & 442620108270801 \\
6 & 443020108171001 \\
7 & 443223107503001 \\
8 & 444832108302501
\end{tabular}

1

$\frac{1}{2}$

1
2
3
4
5
6
7

$\begin{array}{ll}1 & 430335108221301 \\ 2 & 430414108223301 \\ 3 & 431107108180502 \\ 4 & 430600108403801 \\ 5 & 431748109122501 \\ 6 & 431839109124401 \\ 7 & 431855109120701 \\ 8 & 432005109142101\end{array}$
Local well number
Water

year(s) sampled
Analysis

schedule
1986

1

BIG HORN COUNTY

49-091-03cbb01

49-092-06

50-093-22dab01

$51-095-14 a$

$52-096-31 b c b 01$

$52-095-04 \mathrm{cdb} 01$

53-091-29cbc

56-097-26ca

CAMPBELL COUNTY

$57-076-15 d d b$

CARBON COUNTY

18-083-18dcc

14-083-03cda

CONVERSE COUNTY

32-071-29adb

32-073-04 cbb01

33-071-30add

$33-071-29 \mathrm{bbb}$

33-071-20bdc01

34-075-31dca01

35-074-11aac01

FREMONT COUNTY

$1 \mathrm{~N}-04 \mathrm{E}-14 \mathrm{dcb} 01$

$1 \mathrm{~N}-04 \mathrm{E}-11$ ccd01

$2 \mathrm{~N}-05 \mathrm{E}-04 \mathrm{bbb0} 1$

$2 \mathrm{~N}-02 \mathrm{E}-32 \mathrm{ccc} 01$

$4 \mathrm{~N}-04 \mathrm{~W}-26 \mathrm{bcb} 01$

$4 \mathrm{~N}-04 \mathrm{~W}-22 \mathrm{adb} 01$

$4 \mathrm{~N}-04 \mathrm{~W}-23 \mathrm{bab} 01$

$4 \mathrm{~N}-04 \mathrm{~W}-09 \mathrm{cad} 01$
1987-88

1987

1987-88

1987

1987

1987-88

1987

1987

1,2

1,2

1,2

1,2

1,2

1,2

1,2

1,2

1988

1,2

1986

1986

1

1

1988

1988,89

1988

1988

1988

1988

1988

1,2

1,2

1,2

1,2

1,2

1,2

1,2

1987

1987

1987

1989

1989

1989

1989

1989
1,2

1,2

1,2

1,2

1,2

1,2

1,2

1,2 
Table 5.--Ground-water-quality sites--Continued

\begin{tabular}{|c|c|c|c|c|}
\hline Site & & & & \\
\hline $\begin{array}{l}\text { num- } \\
\text { ber }\end{array}$ & Station number & $\begin{array}{c}\text { Local well } \\
\text { number }\end{array}$ & $\begin{array}{c}\text { Water } \\
\text { year(s) sampled }\end{array}$ & $\begin{array}{l}\text { Analysis } \\
\text { schedule }\end{array}$ \\
\hline
\end{tabular}

GOSHEN COUNTY

$\begin{array}{ll}1 & 414028104071801 \\ 2 & 422958104134801 \\ 3 & 423527104112901\end{array}$

1

440932106421001

410135104183500

411143104160801

411222104291701

411851104362001

411905104231801

411941104041401

412523104210701

413634104475901

415841110563701

421258110100201

424128110585301

425759111003901

$1 \quad 434141108285401$

$2 \quad 434301108362701$

$1 \quad 422849107291401$

2423536106392401

$3 \quad 423648106375701$

$1 \quad 424303104070701$

2424539104222401

$3 \quad 424654104182501$

$4 \quad 424859104073001$ 20-060-30bdd01

27-061-07db01

30-061-09acc01

JOHNSON COUNTY

48-082-03bdc01

LARAMIE COUNTY

$12-062-03 c c c$
$14-062-12 \mathrm{bcd} 02$
$14-064-1 \mathrm{dba0} 1$
$16-065-36 \mathrm{acb} 01$
$16-063-26 \mathrm{ddd} 01$
$16-060-27 \mathrm{abc0} 1$
$17-062-19 \mathrm{dbc}$
$19-066-17 \mathrm{cdc}$

LINCOLN COUNTY

23-119-16bbb01

26-112-21ddb01

31-119-10abc01

34-119-02bbb01

HOT SPRINGS COUNTY

$8 \mathrm{~N}-03 \mathrm{E}-02 \mathrm{dca} 01$

$9 \mathrm{~N}-02 \mathrm{E}-35 \mathrm{bdb} 01$

NATRONA COUNTY

29-089-16ddc01

30-082-03ccc01

31-081-35bdc01

NIOBRARA COUNTY

32-060-30 cbd01

32-063-12 cbd01

32-062-04a ca01

33-061-24ddc01
1988

1,2

1986

1986

1988

1

1

1,2

1986,90

1986,90

1986,90

1986,90

1986,90

1986,90

1986,90

1986,90

1,2

1,2

1,2

1,2

1,2

1,2

1,2

1,2

1989

1989

1989

1989

1,2

1,2

1,2

1,2

1989

1989

1,2

1,2

1987

1987-88

1987-88

1,2

1,2

1,2

1988

1988

1988

1988
1,2

1,2

1,2

1,2 
Table 5.--Ground-water-quality sites--Continued

\begin{tabular}{|c|c|c|c|c|}
\hline $\begin{array}{l}\text { Site } \\
\text { num- } \\
\text { ber }\end{array}$ & Station number & $\begin{array}{l}\text { Local well } \\
\text { number }\end{array}$ & $\begin{array}{c}\text { Water } \\
\operatorname{year}(\mathrm{s}) \text { sampled }\end{array}$ & $\begin{array}{l}\text { Analysis } \\
\text { schedule }\end{array}$ \\
\hline
\end{tabular}

$\begin{array}{ll}1 & 440732108535601 \\ 2 & 443253109045101 \\ 3 & 444126108513401 \\ 4 & 444147108472801 \\ 5 & 444217108390900 \\ 6 & 444425108483701 \\ 7 & 445744109051901\end{array}$

PARK COUNTY

48-100-18ddc

53-102-25aad01

54-100-2abb01

55-099-33cdb01

55-098-34bcb01

55-099-17cdd01

58-101-31dad01

1987

1987

1987

1987-88

$1987,88,89$

1987

1987

1,2

1,2

1,2

1,2

1,2

1,2

1,2

PLATTE COUNTY

420046104552401

420224104531601

420523104563801

420523104563902

420559104585301

421733105042201

422818105013501

24-067-32bbc01

24-067-21adc01

25-067-31ccd

$25-067-31$ ccc02

25-068-35bcb

27-069-24dcc

29-068-21bcc01

1986,90

1986,90

1986,90

1986,90

1986

1986,90

1986,90

1,2

1,2

1,2

1,2

1

1,2

1,2

SHERIDAN COUNTY

443938106565601

443938106565602

443939107014901

444155106561801

445131106033901

445436107163401

54-084-14bbb01

1988

1,2

54-084-14bbb02

1988

1,2

1988

55-084-35acd 01

1988

56-076-06cab01

1988

1,2

1,2

57-086-17ccc01

1988

1,2

1,2

SUBLETTE COUNTY

\begin{tabular}{l|ll}
$29-112-10 \mathrm{abc01}$ & 1989 & 1,2 \\
$31-110-21 \mathrm{abd01}$ & 1989 & 1,2 \\
$32-108-15 \mathrm{bbd01}$ & 1989 & 1,2 \\
$32-110-04 \mathrm{baa} 01$ & 1989 & 1,2 \\
$34-110-11$ bdb01 & 1989 & 1,2
\end{tabular}

SWEETWATER COUNTY

$1 \quad 420421109235701$

423104110102001

423911109570301

424454109424101

424645109574301

425606109570901

420636109265301

24-106-10daa01

1989

25-106-27 cba01

1989

1,2

1,2

TETON COUNTY

41-116-29cab01

1989

1,2

$\begin{array}{ll}1 & 432913110474201 \\ 2 & 435628110261301\end{array}$

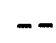

1989

1,2 
Table 5.--Ground-water-quality sites--Continued

\begin{tabular}{|c|c|c|c|c|}
\hline $\begin{array}{l}\text { Site } \\
\text { num- } \\
\text { ber }\end{array}$ & Station number & $\begin{array}{c}\text { Local well } \\
\text { number }\end{array}$ & $\begin{array}{c}\text { Water } \\
\text { year(s) sampled }\end{array}$ & $\begin{array}{l}\text { Analysis } \\
\text { schedule }\end{array}$ \\
\hline \multicolumn{5}{|c|}{ UINTA COUNTY } \\
\hline $\begin{array}{l}1 \\
2 \\
3 \\
4\end{array}$ & $\begin{array}{l}410836110490501 \\
411623110221801 \\
411741110185501 \\
412555111013201\end{array}$ & $\begin{array}{l}14-119-34 d d b 01 \\
15-111-16 \mathrm{dcd} 01 \\
15-114-07 \mathrm{~b} c \mathrm{c} 01 \\
17-120-30 \mathrm{abd} 01 \\
\\
\text { WASHAKIE COUNTY }\end{array}$ & $\begin{array}{l}1989 \\
1989 \\
1989 \\
1989\end{array}$ & $\begin{array}{l}1,2 \\
1,2 \\
1,2 \\
1,2\end{array}$ \\
\hline $\begin{array}{l}1 \\
2 \\
3 \\
4 \\
5 \\
6\end{array}$ & $\begin{array}{l}435720108005701 \\
435724108010901 \\
435724108011601 \\
440334107542301 \\
440547107525701 \\
440915107532501\end{array}$ & $\begin{array}{l}46-093-15 c a b 01 \\
46-093-15 b d d 01 \\
46-093-15 b c c 01 \\
47-092-09 b c c 01 \\
48-092-27 c c d 01 \\
48-092-04 d d c 01\end{array}$ & $\begin{array}{l}1988 \\
1987,88,89 \\
1987-88 \\
1987-88 \\
1987-88 \\
1987-88\end{array}$ & $\begin{array}{l}1,2 \\
1,2 \\
1,2 \\
1,2 \\
1,2 \\
1,2\end{array}$ \\
\hline \multicolumn{5}{|c|}{ WESTON COUNTY } \\
\hline $\begin{array}{l}1 \\
2 \\
3 \\
4 \\
5 \\
6\end{array}$ & $\begin{array}{l}435722104210701 \\
440610104471901 \\
440632104455603 \\
440636104451804 \\
440640104450001 \\
440642104443802\end{array}$ & $\begin{array}{l}46-062-19 \mathrm{bca} 01 \\
48-066-33 \mathrm{abc01} \\
48-066-26 \mathrm{cb} 03 \\
48-066-26 \mathrm{cbd} 04 \\
48-066-26 \mathrm{cad} 01 \\
48-066-26 \mathrm{dbc02}\end{array}$ & $\begin{array}{l}1988 \\
1988 \\
1988,89,90 \\
1988,89,90 \\
1988,89,90 \\
1988,89,90\end{array}$ & $\begin{array}{l}1,2 \\
1,2 \\
1,2 \\
1,2 \\
1,2 \\
1,2\end{array}$ \\
\hline
\end{tabular}

Table 6.--Streamflow stations discontinued in water years 1989 and 1990

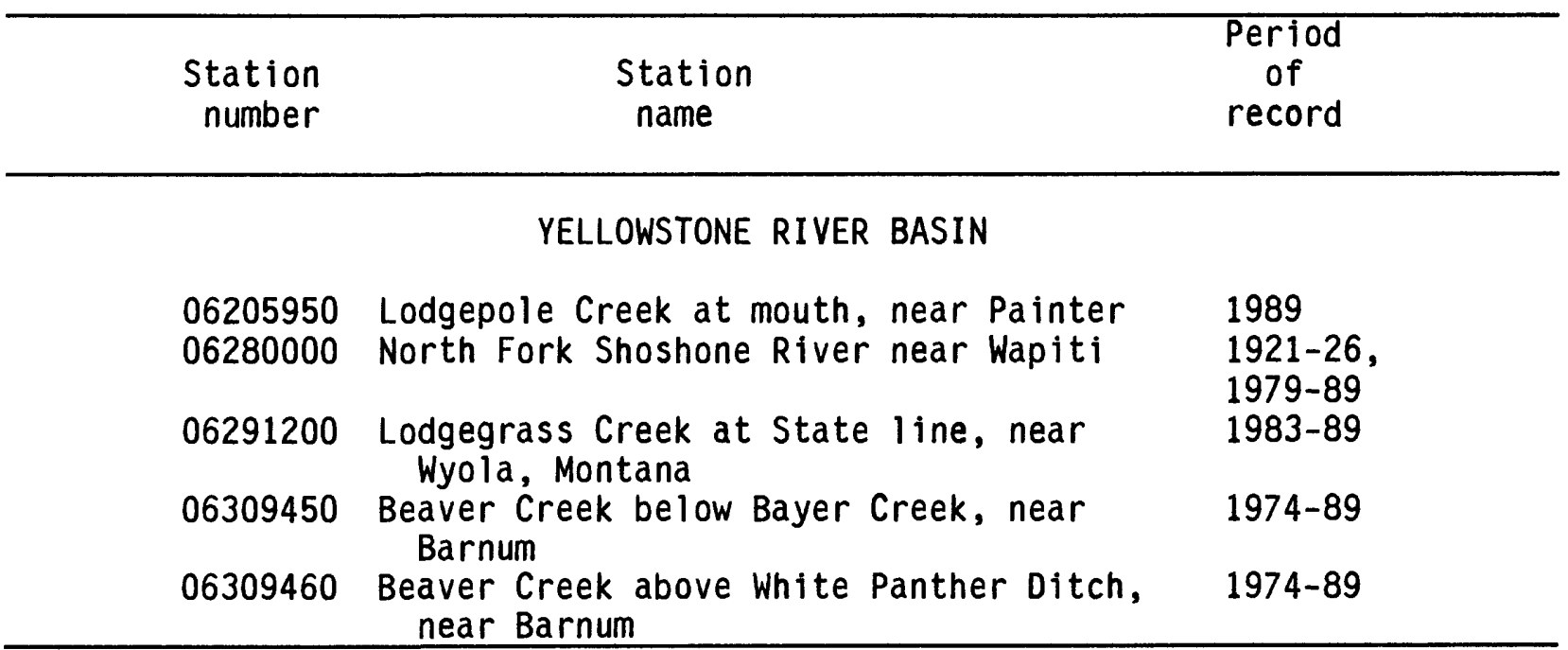


Table 7.--Surface-water-quality stations discontinued in water years 1989 and 1990

\begin{tabular}{cccc}
\hline $\begin{array}{c}\text { Station } \\
\text { number }\end{array}$ & $\begin{array}{c}\text { Station } \\
\text { name }\end{array}$ & $\begin{array}{c}\text { Period } \\
\text { of } \\
\text { record }\end{array}$ & $\begin{array}{c}\text { other data } \\
\text { still being } \\
\text { collected }\end{array}$ \\
\hline
\end{tabular}

YELLOWSTONE RIVER BASIN

$\begin{array}{cl}06189000 & \begin{array}{c}\text { Blacktail Deer Creek near Mammoth, } \\ \text { Yellowstone National Park }\end{array} \\ 06282900 & \text { Shoshone River above Dry Creek, near Cody } \\ 06284450 & \text { Bitter Creek below sewage lagoon, near } \\ & \text { Powell } \\ 06286200 & \text { Shoshone River at Kane } \\ 06305700 & \text { Goose Creek near Acme } \\ 06310000 & \text { Red Fork near Barnum } \\ 06312000 & \text { North Fork Powder River near Kaycee } \\ 06313000 & \text { South Fork Powder River near Kaycee }\end{array}$

1989

Streamflow

1974-89

1981-89

1976-89

$1984-89$

$1987-90$

$1987-90$

1949-53, 1968-81, 1983-85, 1986-90

Streamflow

CHEYENNE RIVER BASIN

06426400 Donkey Creek near Moorcroft

06427500 Belle Fourche River below Keyhole Reservoir

1977-89

1984-89 Streamflow

\section{PLATTE RIVER BASIN}

06625000 Encampment River at mouth, near Encampment

06634620 Little Medicine Bow River at Boles Spring, near Medicine Bow

06636000 North Platte River above Pathfinder Reservoir

06645000 North Platte River below Casper

06652000 North Platte River at Orin

06660070 Laramie River above Howell

413918- Chugwater Creek at Platte-Laramie

105021401 County line, near Chugwater

06669500 Chugwater Creek at Chugwater

1965-89 Streamflow

1985-89 Streamf 1 ow

1969-82, $1987-89$

1950-52, 1957-59,

1967-89

1966-89

$1980-89$

1984-89

Streamf low 
Table 7.--Surface-water-quality stations discontinued in water years 1989 and $1990--C o n t i n u e d$

\begin{tabular}{|c|c|c|c|}
\hline $\begin{array}{l}\text { Station } \\
\text { number }\end{array}$ & $\begin{array}{l}\text { Station } \\
\text { name }\end{array}$ & $\begin{array}{l}\text { Period } \\
\text { of } \\
\text { record }\end{array}$ & $\begin{array}{l}\text { Other data } \\
\text { still being } \\
\text { collected }\end{array}$ \\
\hline \multicolumn{4}{|c|}{ GREEN RIVER BASIN } \\
\hline $\begin{array}{l}09221650 \\
09222000 \\
09224050 \\
09229500\end{array}$ & $\begin{array}{l}\text { Smiths Fork near Lyman } \\
\text { Blacks Fork near Lyman } \\
\text { Hams Fork near Diamondville } \\
\text { Henrys Fork near Manila, Utah }\end{array}$ & $\begin{array}{l}1974-89 \\
1962-89 \\
1975-89 \\
1951-89\end{array}$ & Streamflow \\
\hline \multicolumn{4}{|c|}{ BEAR RIVER BASIN } \\
\hline 10018900 & Yellow Creek at mouth, near Evanston & $1984-89$ & \\
\hline
\end{tabular}

Table 8.--Sediment stations discontinued in water years 1989 and 1990

\begin{tabular}{ccc}
\hline $\begin{array}{c}\text { Station } \\
\text { number }\end{array}$ & $\begin{array}{c}\text { Station } \\
\text { name }\end{array}$ & $\begin{array}{c}\text { Period } \\
\text { of } \\
\text { record }\end{array}$ \\
06635000 & $\begin{array}{c}\text { Medicine Bow River above Seminoe } \\
\text { Reservoir, near Sinclair } \\
\text { Porth Platte River above Pathfinder } \\
\text { Reservoir }\end{array}$ & $1988-89$ \\
06636000 & $1988-89$ \\
\hline
\end{tabular}


Table 9.--Ground-water-level observation wells discontinued in water years 1989 and 1990

\begin{tabular}{|c|c|c|c|}
\hline Station number & Local well number & $\begin{array}{l}\text { Period } \\
\text { of } \\
\text { record }\end{array}$ & Local name \\
\hline \multicolumn{4}{|c|}{ CARBON COUNTY } \\
\hline $\begin{array}{l}415430106493801 \\
415535106482301\end{array}$ & $\begin{array}{l}22-084-01 b c b 01 \\
23-083-31 b b b 01\end{array}$ & $\begin{array}{l}1983-89 \\
1985-89\end{array}$ & $\begin{array}{l}\text { St. Marys Ditch } \\
\text { Medicine Bow \#1 }\end{array}$ \\
\hline \multicolumn{4}{|c|}{ GOSHEN COUNTY } \\
\hline 413852104115801 & $19-061-04 a b c 01$ & $1972-88$ & F. Sanders \\
\hline
\end{tabular}




\section{DATA-COLLECTION PROGRAMS}

PROJECT TITLE: Surface-water stations (WY 00-001)

FUNDING AGENCIES: Wyoming State Engineer, Wyoming Department of Environmental Quality, Wyoming Water Development Commission, Wyoming Water Research Center, Teton County, Uinta County, Sheridan Area Water Supply-Joint Powers Board, City of Gillette, Northern Arapaho Tribe, Shoshone Tribe, Midvale Irrigation District, U.S. Bureau of Reclamation, U.S. Corps of Engineers, U.S. Forest Service, and USGS

PROJECT LEADER: Stanley A. Druse

FIELD LOCATION: Statewide

PERIOD OF PROJECT: Ongoing

PROBLEM: Surface-water information is needed for surveillance, planning, design, hazard warning, operation, and management in related fields such as water supply, hydroelectric power, flood control, irrigation, bridge and culvert design, wildlife management, pollution abatement, flood-plain management, and water-resources development. To provide this information, an appropriate data base is necessary.

OBJECTIVE: (1) Collect sufficient surface-water data to satisfy needs for current-purpose uses such as (a) assessment of water resources,

(b) operation of reservoirs and irrigation projects, (c) prediction of stage or discharge, (d) pollution controls and disposal of wastes, (e) discharge data to accompany water-quality measurements, (f) compact and legal requirements, and $(\mathrm{g})$ research or special studies; and (2) collection of data necessary for analytical studies to define for any location the statistical properties of, and trends in, the occurrence of water in streams and lakes for use in planning and design.

APPROACH: Standard methods of data collection will be used as described in the series, "Techniques of Water-Resources Investigations of the U.S. Geological Survey, "and partial-record gaging will be used where it serves the required purpose instead of complete-record gaging.

PROGRESS AND SIGNIFICANT RESULTS: Computation and compilation of surfacewater data for water year 1989 (fiscal year 1989) data reports were completed by mid-March 1990 and 1991, allowing the Wyoming District to meet the Division's goal of having the report to the printer by April 1. The level of activity continued to increase during 1990 with the addition of 12 new or reactivated continuous-record stations. Three stations were discontinued, effective at the start of water year 1990, and one is to be discontinued at the end of water year 1990. The Wyoming State Engineer's Office continues to operate 26 gages, mostly seasonal, for direct-services credit. Work was initiated as part of the District's safety program to install handrails on cableway platforms at a rate of about 10 per year. 
PLANS FOR FISCAL YEAR 1991: The regulation of irrigation water continues to cause problems between Indian and non-Indian irrigators in the Wind River Indian Reservation. Part of the problem is insufficient streamflow stations to monitor the flow in major streams and selected tributaries adequately. This provides potential for increasing the monitoring network within and adjacent to the Reservation. The goals of installing four data-collection platforms and rehabilitating cableways will be continued. Publication of a gaging-station index is planned.

REPORTS PUBLISHED DURING FISCAL YEARS 1989 and 1990:

Druse, S.A., Glass, W.R., McCollam, P.B., and Peterson, D.A., 1989, Waterresources data, Wyoming--water year 1988: U.S Geological Survey WaterData Report, WY-88-1, 518 p.

Druse, S.A., Glass, W.R., McCollam, P.B., and Peterson, D.A., 1990, Waterresources data, Wyoming--water year 1989: U.S. Geological Survey WaterData Report, WY-89-1, 516 p.

PROJECT TITLE: Ground-water stations (WY 00-002)

FUNDING AGENCIES: Wyoming State Engineer and USGS

PROJECT LEADER: Hugh I. Kennedy

FIELD LOCATION: Statewide

PERIOD OF PROJECT: Ongoing

PROBLEM: (1) Long-term ground-water-level records are needed to evaluate the effects of climatic variations on the recharge to and discharge from the ground-water systems to provide a data base from which to (a) measure the effects of development, (b) assist in the prediction of future supplies, and (c) provide data for management of the resource. (2) Short-term water-level records also are needed for (a) ground-water resources assessment, (b) areal investigations, and (c) water-use investigations.

OBJECTIVE: (1) Collect sufficient water-level data to provide a data base so that the general hydrologic response to climatic variations and induced stresses is known and potential problems can be defined early enough to allow planning and management; and (2) provide a data base against which short-term records acquired in areal studies can be analyzed. This analysis must (a) provide an assessment of the ground-water resource, (b) allow prediction of future conditions, (c) detect and define pollution and supply problems, and (d) provide the data base necessary for ground-water management.

APPROACH: The most advantageous locations for long-term observations will be determined. This network will be refined as records become available and detailed areal studies of the ground-water system more closely define the aquifers, their properties, and the stresses to which they are subjected. 
PROGRESS AND SIGNIFICANT RESULTS: The biennial ground-water-level report for the 10-year period 1980-89 was completed and published. The network of observation wells continued at about the same level--87 wells. Computation and compilation of the data have been maintained at a near-current status. The Wyoming State Engineer's Office continues to operate about two-thirds of the network wells for direct-services credit.

PLANS FOR FISCAL YEAR 1991: Continue to keep computation and compilation of data at "near current" status. The Wyoming State Engineer will continue to operate a majority of the wells for direct-services credit.

REPORTS PUBLISHED DURING FISCAL YEARS 1989 AND 1990:

Druse, S.A., Glass, W.R., McCollam, P.B., and Peterson, D.A., 1989, Waterresources data, Wyoming--water year 1988: U.S. Geological Survey WaterData Report, WY-88-1, 518 p.

Druse, S.A., Glass, W.R., McCollam, P.B., and Peterson, D.A., 1990, Waterresources data, Wyoming--water year 1989: U.S. Geological Survey WaterData Report, WY-89-1, 516 p.

Kennedy, H.I., and Green, S.L., 1990, Ground-water levels in Wyoming, 1980 through September 1989: U.S. Geological Survey Open-File Report 90-106, $136 \mathrm{p}$.

PROJECT TITLE: Water-quality stations (WY 00-003)

FUNDING AGENCIES: Wyoming Department of Agriculture, Wyoming State Engineer, Wyoming Department of Environmental Quality, Wyoming Water Development Commission, City of Gillette, Northern Arapaho Tribe, Shoshone Tribe, U.S. Bureau of Reclamation, U.S. Forest Service, and USGS

PROJECT LEADER: David A. Peterson

FIELD LOCATION: Statewide

PERIOD OF PROJECT: Ongoing

PROBLEM: Water-resource planning and water-quality assessment require a nationwide base level of standardized information. For intelligent planning and realistic assessment of the water resource, the chemical and physical quality of surface and ground water must be defined and monitored.

OBJECTIVE: Provide a national bank of water-quality data for broad Federal and State planning and action programs and to provide data for State and Federal management of interstate waters.

APPROACH: A network of water-quality stations will be operated at stream sites to provide data on average chemical concentrations, loads, and trends as required by planning and management agencies. Selected ground-water wells also will be sampled. 
PROGRESS AND SIGNIFICANT RESULTS: Water-quality samples were collected at 119 surface-water stations, in cooperation with State, local, and Federal agencies. Adjustments to the surface-water monitoring network included increased sampling of nonpoint-source pollutants, particularly suspended sediment. The ground-water monitoring program focused on the southeastern quadrant of the State; 25 wells were sampled for herbicides, major dissolved constituents, and field measurements. Data were compiled, checked, and published in the annual data report for 1989. The report was sent to the printer by the Division goal date of April 1.

PLANS FOR FISCAL YEAR 1991: Minor adjustments in the surface-water-quality network are expected. The ground-water-quality monitoring program will focus on the northwestern quadrant of the state.

REPORTS PUBLISHED DURING FISCAL YEARS 1989 AND 1990:

Druse, S.A., Glass, W.R., McCollam, P.B., and Peterson, D.A., 1989, Waterresources data, Wyoming--Water year 1988: U.S. Geological Survey WaterData Report, WY-88-1, $518 \mathrm{p}$.

Druse, S.A., Glass, W.R., McCollam, P.B., and Peterson, D.A., 1990, Waterresources data, Wyoming--Water year 1989: U.S. Geological Survey WaterData Report, WY-89-1, 516 p.

PROJECT TITLE: Sediment stations (WY 00-004)

FUNDING AGENCIES: Wyoming Water Development Commission, Wyoming Department of Environmental Quality, City of Gillette, U.S. Bureau of Reclamation, U.S. Forest Service, and USGS

PROJECT LEADER: David A. Peterson

FIELD LOCATION: Statewide

PERIOD OF PROJECT: Ongoing

PROBLEM: Water-resource planning and water-quality assessment require a nationwide base level of relatively standardized information. Sediment concentrations and discharges in rivers and streams must be defined and monitored.

OBJECTIVE: (1) Provide a national bank of sediment data for use in broad Federal and State planning and action programs, (2) provide data for Federal and State management of interstate water, and (3) provide data for interpretation in areal studies.

APPROACH: A network of sediment stations will be established and operated to provide data on areal and temporal averages and trends of sediment concentration, sediment discharges, and particle-size distribution of sediment being transported by rivers and streams. 
PROGRESS AND SIGNIFICANT RESULTS: Computation and compilation of sediment data were processed ahead of schedule, helping to allow timely publication of the 1989 data report. Four continuous-record stations were operated during the year; and sediment samples were collected on an intermittent basis at 25 stations. All concentrations and 0.062-millimeter splits were analyzed in the District Sediment Laboratory. Samples also were processed for the Colorado and Utah Districts. The report of results of an investigation of sediment yields in small ephemeral streams was completed and prepared for technical review.

PLANS FOR FISCAL YEAR 1991: Continuation of data collection at the previous year's stations. The analysis procedures used in the sediment laboratory will be upgraded through linking of the laboratory weighing balances to the computer and use of associated software.

REPORTS PUBLISHED DURING FISCAL YEARS 1989 AND 1990:

Druse, S.A., Glass, W.R., McCollam, P.B., and Peterson, D.A., 1989, Waterresources data, Wyoming--water year 1988: U.S. Geological Survey WaterData Report, WY-88-1, 518 p.

Druse, S.A., Glass, W.R., McCollam, P.B., and Peterson, D.A., 1990, Waterresources data, Wyoming--water year 1989: U.S. Geological Survey WaterData Report, WY-89-1, 516 p.

\section{WATER-RESOURCES-APPRAISAL PROJECTS}

PROJECT TITLE: Water-use data system for Wyoming (WY 84-007)

FUNDING AGENCIES: Wyoming State Engineer and USGS

PROJECT LEADER: Charles L. Qualls

FIELD LOCATION: Statewide

PERIOD OF PROJECT: January 1984 through September 1991

PROBLEM: The demand for water for a variety of competing uses in Wyoming is expected to continue to increase. Planners and managers at all levels of government need detailed, accurate water information in order to assure that maximum benefits are derived from the available water. Available water-use data for Wyoming may be inconsistent for current management needs. The USGS has designed and implemented a program to develop a uniform national data base of water-use information. A water-use data system is needed in Wyoming, not only to meet national needs, but to provide State agencies with the detailed information needed for water planning and administration.

OBJECTIVE: Establish a water-use data system that is responsive to the needs of water planners at the State and national levels. The system will provide for the collection, storage, retrieval, and dissemination of water-use data. The data base will include quantitative information about water rights, withdrawals, transfers, and returns. 
APPROACH: The State Water-Use Data System (SWUDS), part of the National Water Information System (NWIS) of the USGS, has been loaded onto the Wyoming District computer. Population of the SWUDS is to be accomplished, regionby-region or basin-by-basin, as project work in the regions or basins allows, beginning with water-use data to be collected as part of the Wind River Indian Reservation water-use program.

PROGRESS AND SIGNIFICANT RESULTS: The Wyoming State Engineer's Office and other agencies were contacted concerning creation of a water-use steering committee. Progress was made in designing a Geographic Information System (GIS) for compiling water-use data in lieu of entry into the State Water Use Data System. A project proposal was presented to the Wyoming State Engineer for creation of a GIS data base of irrigated lands in the North Platte River basin; this data base is to be used by USGS personnel to estimate irrigation water use in the basin. Another project proposal was prepared and discussed to create a GIS data base of water wells throughout the State of Wyoming. Planning has begun for the compilation of data for the publication Estimated Use of Water in the United States, 1990. Algorithms were written to calculate commercial, industrial, and mining water use for Wyoming, based on employment data and employee per-capita water use.

PLANS FOR FISCAL YEAR 1991: A water-use steering committee will be organized and convened. Project work will concentrate on compiling Wyoming data for the publication Estimated Use of Water in the United States, 1990. Data for this compilation will be entered into a GIS-based data system for later transfer into the USGS Aggregated Water-Use Data System. Personnel of the Wyoming State Engineer's Office are being encouraged to participate by defining needs of the State for water-use studies by personnel of the USGS and the State Engineer's Office.

\section{REPORTS COMPLETED DURING FISCAL YEAR 1991:}

Schuetz, J.R., in press, Wyoming [Water supply and demand], in National water summary 1987--Selected hydrologic events and water-supply and demand: U.S. Geological Survey Water-Supply Paper 2350.

PROJECT TITLE: Site characterization and preparation of a remedial-action plan for the Installation Restoration Program at F.E. Warren Air Force Base, Wyoming (WY 86-095)

FUNDING AGENCY: U.S. Air Force

PROJECT LEADER: L. Rodney Larson

FIELD LOCATION: Southeastern Wyoming

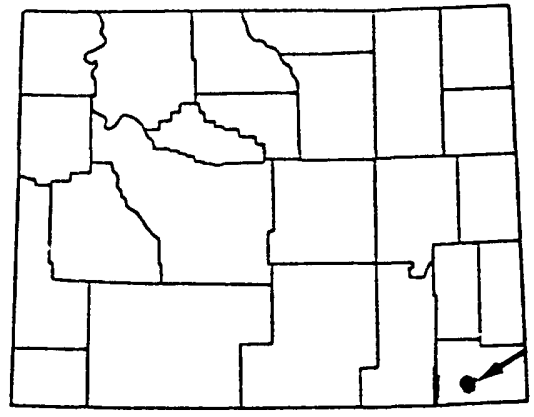

PERIOD OF PROJECT: December 1985 through December 1991 
PROBLEM: As part of its operations at F.E. Warren Air Force Base, the U.S. Air Force has used, stored, and disposed of various hazardous materials. During 1985-90, geotechnical studies showed that soil, ground water, or surface water was contaminated at 24 sites. The hazardous materials primarily were trichloroethene, gasoline or oil, ethylene glycol, and battery acid.

OBJECTIVE: The remedial investigation will determine the nature and extent of contamination at each site, assess the impact of the contaminants on the environment, and summarize the data and conclusions in a final report. This information will then be used by the Air Force to determine appropriate remedial action for each site.

APPROACH: The investigation is planned to determine the extent and movement of contaminants in the soil and water. Observation wells and boreholes will be drilled and logged, water-level measurements obtained, aquifer tests performed, and a potentiometric-surface map prepared. Streamflow measurements will be made and historical streamflow data analyzed. Soil and water samples will be obtained and soil-gas and surface geophysical surveys will be made to detect and delineate contaminant plumes.

PROGRESS AND SIGNIFICANT RESULTS: A prel iminary draft report was completed and submitted to the Air Force in December 1989 for review. The base was added to the Environmental Protection Agency National Priorities List; the designation was final in February 1990. This will require additional work concerning remedial investigation and feasibility study, leading to remedial action such as cleanup. During water year 1990 , geotechnical work was conducted at several individual spill sites, and these data will be included in the final report.

PLANS FOR FISCAL YEAR 1991: Review comments for the phase 1 remedial investigation report have been received from the Air Force. The report was completed and delivered by May 1, 1991. Designation of the base to the National Priorities List will require additional comprehensive onsite studies and individual reports concerning remedial investigation for specific spill sites and operable units.

PROJECT TITLE: Flood investigation for Cheyenne, Wyoming (WY 87-100)

FUNDING AGENCY: Wyoming Highway Department, Laramie County, City of Cheyenne, and USGS

PROJECT LEADER: James G. Rank1

FIELD LOCATION: Southeastern Wyoming

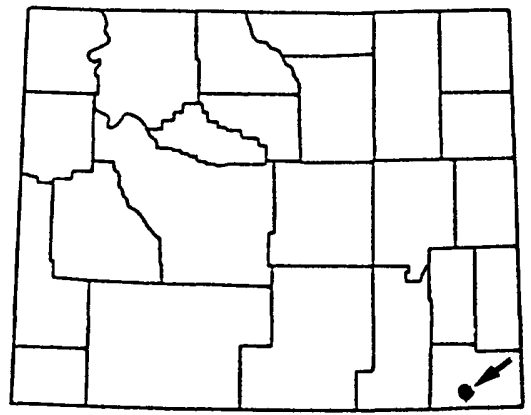

PERIOD OF PROJECT: October 1986 through September 1992 
PROBLEM: The City of Cheyenne, Wyoming, is susceptible to extreme flooding because of its location in the foothills of the Laramie Mountains. Streams in this area pose a significant flood hazard from intense thunderstorms, especially during the months of July and August. Although more than 80 years of precipitation data are available, the relation between precipitation and runoff has not been defined for rural areas around Cheyenne or for urban areas within the city limits.

OBJECTIVE: (1) Determine the relation between rainfall and runoff for both rural and urban areas, and (2) use the results of the rainfall and runoff relations in conjunction with the 80 years of precipitation data to develop predictions of peak and volume frequencies. The peak and volume frequencies will be used by the City of Cheyenne to design the proper size openings for hydraulic structures.

APPROACH: Three streamflow-gaging stations equipped with stage sensors and recording precipitation gages will be installed on channels of three small drainage basins entering the Cheyenne area. An additional site will be installed on Henderson Drain to sample a completely urbanized area. A streamflow-gaging station will be located about 15 miles west of Cheyenne for collecting hydrologic data. All sites will be equipped with a floodalert system operated by the National Weather Service. Hydrologic data will be collected for 4 to 5 years.

PROGRESS AND SIGNIFICANT RESULTS: Precipitation for the first 6 months of water year 1990 was 140 percent of normal. Snowfall for March exceeded a previous record resulting in record snowmelt runoff at Crow Creek below North Fork near Silver Crown. Although precipitation was above normal for May, June, and July, flooding was minor. Numerous discharges were measured and preliminary rating curves were developed for Crow Creek and for Henderson Drain. No additional work was done on the Childs Draw flood study because funding was not received until September 1990.

PLANS FOR FISCAL YEAR 1991: Backwater computations for Dry Creek and Dry Creek tributary will be completed, and rating curves and tables will be developed. Levels will be run at all streamflow-gaging stations in the urban network. Flood-profile computations will be completed for Childs Draw between Ridge Road and Yellowstone Highway. The Childs Draw flood study has been expanded to include the reach between Ridge Road and Braehill Road, between Yellowstone Highway and Interstate-25, and a major tributary extending from Four-Mile Road to Interstate-25. The added reaches will be surveyed in spring 1991.

PROJECT TITLE: Streamflow and channel characteristics of the Bear River at Evanston, Wyoming (WY 88-105)

FUNDING AGENCY: Wyoming Parks and Recreation Commission, Uinta County, City of Evanston, and USGS

PROJECT LEADER: Mark E. Smith

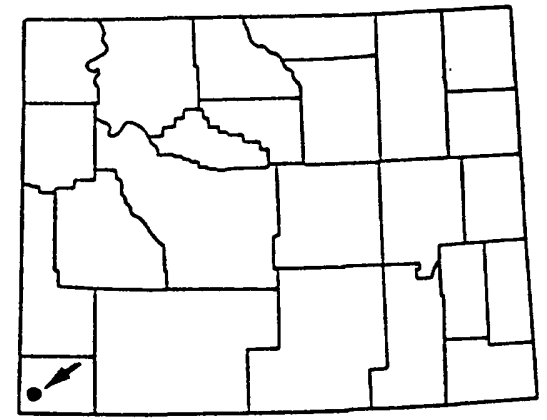


FIELD LOCATION: Southwestern Wyoming

PERIOD OF PROJECT: January 1987 through September 1991

PROBLEM: Channel alterations caused by high flows of 1983 and 1984 , by landowners constricting and straightening the channel to increase property area, and by the City of Evanston adding riprap and dikes to control bank erosion and flooding have resulted in channel instability. The channel instability has caused degradation that has lowered the channel through the town as much as 3 feet. Bank erosion has caused water-quality problems, the loss of fish habitat, increased flooding in some areas, and the destruction of streamside property in other areas.

OBJECTIVE: Provide background hydrologic and hydraulic information to be used as an aid to a comprehensive plan for the correction of channel problems and the rebeautification of the Bear River at and near Evanston.

APPROACH: Aerial photos will be used to document changes in channel and sinuosity. An advisory committee of hydrologists, engineers, fishery biologists, and planners will review background data and make recommendations for corrective actions, and possible funding. The USGS will combine a geomorphic analysis of the river, in which maps and aerial photographs are used to identify a stable channel pattern, with a hydraulic analysis of flow using a river computer model.

PROGRESS AND SIGNIFICANT RESULTS: Data collection was completed in November 1989 when low-flow water-quality samples were collected. Computer-model calibration was completed for the present channel, and bankfull discharge was identified for a reconstructed channel slope with cross-sectional hydraulics. The model was used to evaluate the haybale stabilization structure. The historic channel pattern of the early 1900s was simulated with the model and compared with the present-day channel. Hydraulic calculations for flow over the proposed diversion structure were completed for the 100-year flood. Report preparation was begun near the end of the year.

PLANS FOR FISCAL YEAR 1991: The project report will be completed and reviewed. Hydraulic and geomorphic analyses, along with all onsite data, will be compiled and included in the report.

PROJECT TITLE: Field screening study of water quality, bottom sediments, and biota of the Riverton Irrigation Project, Fremont County, Wyoming (WY 88-106)

FUNDING AGENCY: Office of the Secretary of the Interior

PROJECT LEADER: David A. Peterson

FIELD LOCATION: Central Wyoming

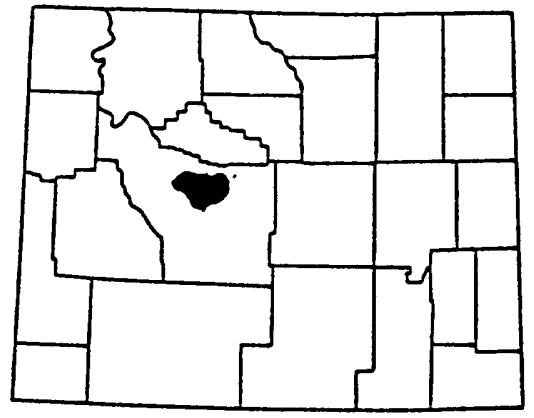


PERIOD OF PROJECT: October 1987 through September 1991

PROBLEM: The U.S. Department of the Interior Irrigation Drainage Program selected 19 areas in the Western United States where irrigation drainage may have negative effects on wildlife, such as the deformed birds observed at Kesterson National Wildlife Refuge in California. Nine areas were studied during 1986-87; the Riverton Project is one of 10 areas to be studied during 1989-90.

OBJECTIVE: Determine whether irrigation drainage has caused or has the potential to cause harmful effects on human health or on fish and wildlife, or to affect other beneficial uses of the water.

APPROACH: Sampling sites for surface water and bottom sediment will be selected at the upstream and downstream edges of the project area, as well as within. Streams and canals to be sampled include Muddy Creek, Fivemile Creek, and Wyoming Canal. Ocean Lake and other State wildfowl management areas also will be sampled. Water analyses will include trace elements and pesticides; bottom sediments will be analyzed for major and minor elements; and biota from several trophic levels will be analyzed for trace elements and organochlorine pesticides.

PROGRESS AND SIGNIFICANT RESULTS: The project report, co-authored by USGS (lead), U.S. Fish and Wildlife Service, and U.S. Bureau of Reclamation, titled "Reconnaissance investigation of water quality, bottom sediment, and biota associated with irrigation drainage in the Riverton Reclamation Project, Wyoming, 1988-89, "was approved for publication as Water-Resources Investigations Report 90-4187. Project is completed.

REPORTS COMPLETED DURING FISCAL YEAR 1991:

Peterson, D.A., and others, 1991, Reconnaissance investigation of water quality, bottom sediment, and biota associated with irrigation drainage in the Riverton Reclamation Project, Wyoming, 1988-89: U.S. Geological Survey Water-Resources Investigations Report 90-4187, $84 \mathrm{p}$.

PROJECT TITLE: Description and analysis of water-level changes in the High Plains aquifer, Wyoming (WY 88-107)

FUNDING AGENCY: Wyoming State Engineer and USGS

PROJECT LEADER: Kirk A. Miller

FIELD LOCATION: Southeastern Wyoming

PERIOD OF PROJECT: April 1990 through September 1992

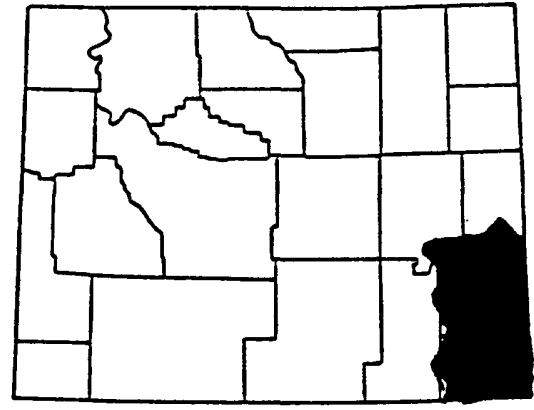

PROBLEM: In response to concerns over the status of conditions in the High Plains (Ogallala) aquifer, Congress has directed the USGS to monitor water levels in the aquifer and to report the results annually to them. 
OBJECTIVE: The directive from Congress will be met by preparing an annual report with information concerning (1) changes in water levels or storage, (2) changes in water quality with time, (3) factors such as climatic and land-use conditions that affect the aquifer, and (4) results of an analysis of the relations between causative factors and changes in the aquifer.

APPROACH: Data on ground-water levels will be collected, and new observation wells will be installed where necessary. Data that have been collected by State agencies will be compiled and reviewed. All data will be analyzed and presented in annual reports.

PROGRESS AND SIGNIFICANT RESULTS: Initial results indicate supplemental water-level data are needed. Areas outside local observation-well networks have few data points. Data-deficient areas were delineated. Well data base searches were initiated. Eleven wells were located for measurement once each water year to supplement existing observation-well data. The supplemental wells were photographed, and water levels were measured. Water-level data for existing observation wells were obtained by the High Plains regional coordinator through the USGS Automated Data Processing System. Well header-file information was provided as requested.

PLANS FOR FISCAL YEAR 1991: Slug tests will be performed on the supplemental wells to determine if adequate communication between each well and the aquifer exists. Well files will be entered and updated in the existing Ground Water Site Inventory data base for the supplemental wells in the study. Annual water levels will be measured and transmitted to the regional coordinator.

PROJECT TITLE: Detailed study and assessment of irrigation drainage in the Kendrick Reclamation Project area, Wyoming (WY 88-111)

FUNDING AGENCY: Office of the Secretary of the Interior

PROJECT LEADER: Randolph B. See

FIELD LOCATION: Central Wyoming

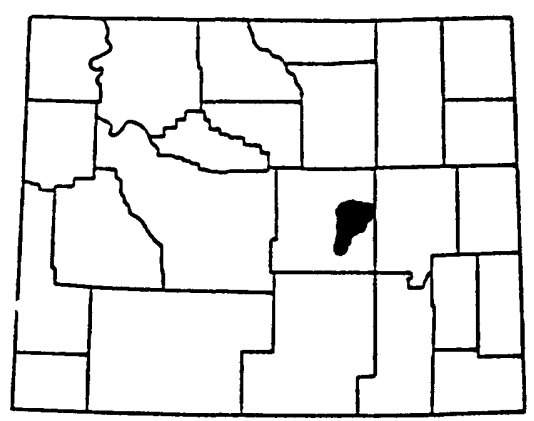

PERIOD OF PROJECT: October 1987 through September 1991

PROBLEM: Samples taken on or near the Kendrick Project have shown elevated concentrations of selenium in water, bottom sediments, and biota. The studies to date have been at a reconnaissance level, and, with the data currently available, an evaluation of whether the elevated concentrations are localized or widespread requires additional information. In addition, the geochemical and biological processes controlling the mobility and availability of selenium and associated trace elements are not understood at the Kendrick Project. An understanding of these processes is needed to evaluate the magnitude of potential toxicity problems and to provide data for any mitigative measures that may be needed. 
OBJECTIVE: To determine the extent, magnitude, and effects of contaminants associated with irrigation drainage, and, where effects are documented, the sources and exposure pathways that cause contamination.

APPROACH: An interagency study team has been formed. Work elements include: (1) sampling tributaries; (2) locating and sampling domestic and livestock wells; (3) determining bird nesting success, species composition, and frequency of use; (4) determining contaminant levels in rainbow trout and waterfowl; (5) determining relations between trace-element concentrations in Kendrick waterfowl and fish to those in water, sediment, and diet organisms;

(6) determining which irrigated areas are contributing the largest concentrations of selenium; (7) determining the physical and geochemical process controlling selenium mobility; and (8) determining the geologic sources of selenium and associated trace elements.

PROGRESS AND SIGNIFICANT RESULTS: Sampling for selenium in surface and ground water and in birds and fish was completed. Laboratory analys is of all samples was completed, and the results analyzed. A Water-Resources Investigation Report and two journal articles were completed and submitted for colleague review.

PLANS FOR FISCAL YEAR 1991: Each of the three reports in review will be revised after review and submitted for Director's approval. An open-file report will be prepared that lists data for the water and biota samples.

PROJECT TITLE: Quality of surface water and ground water in the Owl Creek basin, Wind River Indian Reservation, Wyoming (WY 88-114)

FUNDING AGENCY: Northern Arapaho Tribe and USGS

PROJECT LEADER: Kathy Muller Ogle

FIELD LOCATION: Central Wyoming

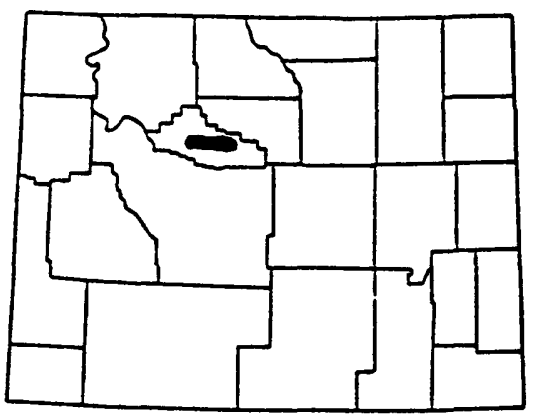

PERIOD OF PROJECT: July 1989 through September 1991

PROBLEM: Large concentrations of dissolved solids limit the use of water in much of the Owl Creek basin. Surface water is used for irrigation, but has a large to very large salinity hazard to crops. Water from the alluvial aquifer generally is unsuitable for most purposes other than stock watering. Water for domestic supply must be hauled to ranches in the area at a substantial cost to the Arapaho Tribe.

OBJECTIVE: To assess the suitability of surface- and ground-water resources in the OWl Creek basin as potential drinking-water sources.

APPROACH: (1) Previously collected data for the Owl Creek basin will be compiled and evaluated; this will include USGS data and data from other sources; (2) where needed, additional surface-water and ground-water data 
will be collected; (3) the data will be compared to the U.S. Environmental Protection Agency drinking-water regulations for major ions and dissolvedsolids concentration.

PROGRESS AND SIGNIFICANT RESULTS: All data gathering and analysis were completed. A draft report was written. The report received editorial, colleague, and reports specialist reviews. A presentation was made at the Wyoming Section, American Water Resources Association annual conference on part of the findings. Project is complete except for the report.

PLANS FOR FISCAL YEAR 1991: The report will be submitted for Director's approval to publish.

PROJECT TITLE: Hydrologic appraisal of the Wind River Indian Reservation, Wyoming (WY 88-115)

FUNDING AGENCY: Northern Arapaho Tribe, Shoshone Tribe, and USGS

PROJECT LEADER: Richard L. Daddow

FIELD LOCATION: Central Wyoming

PERIOD OF PROJECT: July 1990 through September 1992

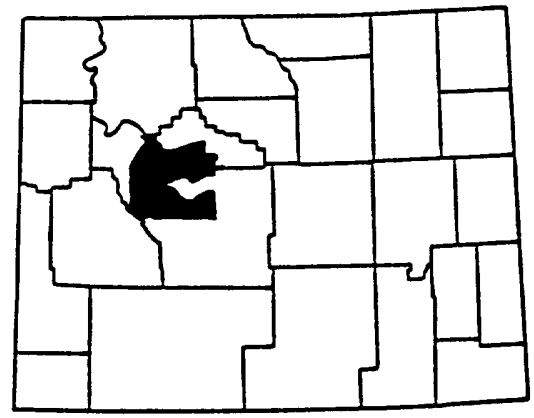

PROBLEM: A comprehensive appraisal of the ground-water resources of the area was undertaken 20 years ago. No comprehensive appraisal of the surfacewater resources has been published, although substantial amounts of data have been gathered. An understanding of the quantity and quality of the water resources of the reservation is necessary before the water resources can be used fully.

OBJECTIVE: (1) Appraise the water resources of the Wind River Indian Reservation; and (2) write a comprehensive report to be used by waterresources managers.

APPROACH: (1) Compile data; (2) do preliminary data analysis to identify areas where more data are needed; (3) develop and implement data-collection plan; and (4) do final data analysis and prepare report.

PROGRESS AND SIGNIFICANT RESULTS: A detailed literature review of the water resources of the project area was completed. All the non-USGS data records for 510 well and 240 spring sites were entered into the alternative, project-base ground-water site inventory (GWSI) data base and verified for data accuracy. All the non-USGS water-quality data (250 records) were entered into the alternative water-quality (QWDATA) data base. All the project-area well and spring data records in the Wyoming GWSI data base were checked for accuracy based on original well-schedule records, and 1,500 site records were updated or corrected. Historic USGS water-quality analyses for 100 well sites were entered into the Wyoming QWDATA data base. Detailed summary tables of all the USGS flow and water-quality data for gaging stations (117 sites) and miscellaneous surface-water sites (42 sites) were compiled and prepared for the project area using a drainage-basin approach. 
A complete quality-assurance review of all water-quality chemical data records was conducted using a computer program developed by the project chief. Onsite parameters were measured and water-quality samples were collected from 75 selected surface-water, spring, and well sites. A project-review meeting was held with tribal and U.S. Bureau of Indian Affairs representatives. The annotated outline of the planned report was modified and updated. It was decided also to prepare an open-file report of hydrologic data for all wells and springs in the project area. Detailed analysis of all the compiled ground-water and surface-water data was started.

PLANS FOR FISCAL YEAR 1991: Data inventory and statistical analysis will be completed and summarized for the hydrogeologic and water-quality characteristics of selected aquifer systems and flow and water-quality characteristics of selected stream sites. A water table map representative of the shallow ground water in the Wind River Formation and the Quaternary deposits in the Wind River basin will be produced. The planned interpretive and hydrologic-data reports will be prepared, written, and completed by March 31, 1992.

PROJECT TITLE: Water quality of the Powder River, Wyoming and Montana (WY 88-116 and MT 88-121)

FUNDING AGENCY: Wyoming State Engineer, Wyoming Water Development Commission, Montana Department of Natural Resources and Conservation, and USGS

PROJECT LEADER: J.B. Lindner-Luns ford (Wyoming) Charles Parrett (Montana)

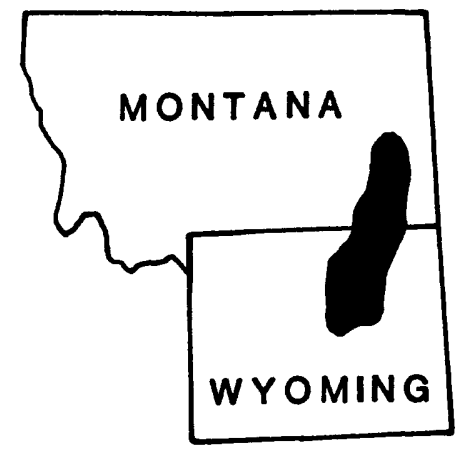

FIELD LOCATION: Northeastern Wyoming and Southeastern Montana

PERIOD OF PROJECT: July 1990 through September 1991

PROBLEM: Water from the Powder River and its tributaries is used for irrigation, industry, and domestic and livestock supply. Water in the downstream reach of the river always has been of marginal quality for irrigation. Dissolved-solids concentrations tend to increase during low flow, particularly during the summer irrigation season, and decrease during high flow, such as spring runoff. Additional knowledge and understanding of the water-quality characteristics of the river system is needed before managers can evaluate potential changes in quality resulting from hydrologic changes.

OBJECTIVE: (1) Compile and expand available water-quality data for the basin; (2) determine water-quality characteristics of the Powder River and its major tributaries; (3) develop a conceptual model of the river system; and (4) develop a computer-based mass-balance accounting model for the river system. 
APPROACH: (1) Compile streamflow and water-quality data, measure mean-daily specific conductance in the Powder River at Sussex, Wyoming, sample 13 sites on a near-monthly basis for 18 months, analyze samples for common ions and field parameters; (2) conduct synoptic flow and water-quality measurements on mainstem and significant tributaries, determine land use and water use, evaluate data for trends; (3) develop a conceptual model; and (4) develop mass-balance model to check conceptual model and to provide managers a tool for future resource evaluation. This work will be done concurrently in Wyoming and Montana by the Wyoming and Montana Districts, USGS, and will be coordinated closely. Reports of the results of the investigations will cover the entire drainage basin of the Powder River.

PROGRESS AND SIGNIFICANT RESULTS: Water-quality sampling at supplemental sites was completed in December 1989. Mass-balance and other statistical analyses of stream discharge and major dissolved constituents in the Powder River were completed. The monthly mass-accounting model was calibrated and verified for both discharge and dissolved-solids concentrations. Potential applications of the model were demonstrated by using the model to predict impacts of several water-management strategies. The project report, co-authored by Wyoming and Montana District personnel, was completed and submitted for editorial review at year's end. Also, a separate report on statistical analyses of trends in water-quality characteristics at selected long-term stations in Wyoming and Montana was completed by the Montana District and was approved by the Director, USGS, for publication as USGS Water-Resources Investigations Report 91-4029.

PLANS FOR FISCAL YEAR 1991: The project report will be given colleague review, revised, and submitted for Director's approval to publish.

PROJECT TITLE: Effects of in-situ oil-shale retorting on water quality near Rock Springs, Wyoming (WY 88-118)

FUNDING AGENCY: U.S. Department of Energy

PROJECT LEADER: J.B. Lindner-Lunsford and Kathy Muller Ogle FIELD LOCATION: Southwestern Wyoming

PERIOD OF PROJECT: July 1990 through September 1991

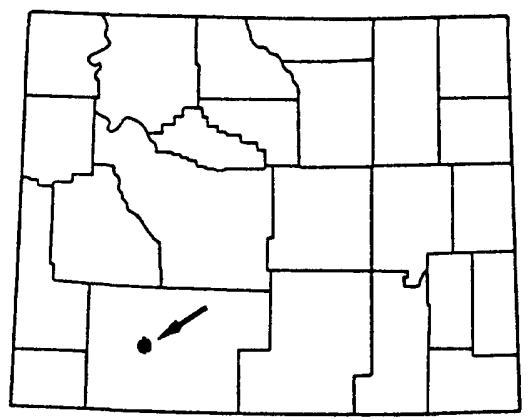

PROBLEM: A variety of experimental in-situ oil-shale retorting techniques was used from 1969-79 at the U.S. Department of Energy sites near Rock Springs, in southwestern Wyoming. Water of poor quality was produced during the experiments. There is concern that the plume of contaminated water might have migrated from the experiment site to a nearby creek, which ultimately discharges into the Green River and Flaming Gorge Reservoir. The geologic structure is such that there is potential for migration of contaminants from the oil-shale aquifer into the underlying aquifer (which can be used for domestic supply); it is unclear whether the two formations are hydraulically connected. 
OBJECTIVE: To determine the current nature and extent of the contamination at all sites in the study area, and to investigate the movement and fate of the contaminants in the hydrologic system.

APPROACH: Twelve to fifteen monitoring wells will be drilled and logged. Wells will be constructed and sampled according to National Water Quality Assessment field procedures for ground water. The wells will have screens 10 to 15 feet in length and will be screened at different depths in the formation to enable definition of the plume in three dimensions and estimation of vertical leakage between layers. Head space will be analyzed onsite using a portable gas chromatograph, and wells will be sampled for a wide range of organic and inorganic constituents.

PROGRESS AND SIGNIFICANT RESULTS: The project report was completed and submitted for publication by the U.S. Department of Energy. The project has been extended into fiscal year 1991 for additional work requested by the U.S. Department of Energy.

PLANS FOR FISCAL YEAR 1991: The project report has received Director's approval and has been submitted for publishing by the U.S. Department of Energy.

PROJECT TITLE: Water resources of Hot Springs County, Wyoming (WY 89-119)

FUNDING AGENCY: Wyoming State Engineer and USGS

PROJECT LEADER: Maria Plafcan

FIELD LOCATION: North-central Wyoming

PERIOD OF PROJECT: October 1988 through September 1991

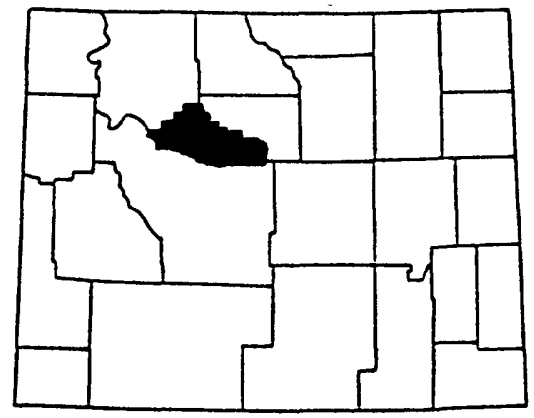

PROBLEM: Ground water of poor chemical quality has long been a problem for residents in the county. Demand for water suitable for domestic and municipal supply has increased as previous supplies have become unsatisfactory because of yield or water quality. Water quality and the potential yield of aquifers currently not used need to be investigated to aid county planners.

OBJECTIVE: To describe the geohydrologic conditions in the county; to determine the general occurrence and chemical quality of ground water, and to describe areas of potential contamination and the availability of ground water.

APPROACH: Representative wells and springs will be inventoried and specific conductance of ground water and base flow will be measured. Samples of ground water will be collected for dissolved constituents. Some groundwater samples will be analyzed to determine if specific contaminants are in the water. Low-flow gains and losses along selected reaches of the Wind 
River, Bighorn River, and tributaries will be measured at specific geologic formations to estimate recharge and discharge. Observation wells will be established and monitored for water-level changes.

PROGRESS AND SIGNIFICANT RESULTS: The inventory of representative wells and springs was completed. Forty-eight sites were inventoried (10 springs and 38 wells). Water-quality samples were collected at 32 sites and were analyzed for selenium, boron, and inorganics or trace elements (depending on geologic unit), in addition to major ions. The largest dissolved-solids concentration (nearly 8,000 milligrams per liter) was from the Cody Shale. A base-flow study was conducted on Grass Creek. Discharge and water-quality samples were collected at 13 sites. The lowest specific-conductance values were at the headwaters (200-300 microsiemens per centimeter).

PLANS FOR FISCAL YEAR 1991: Water-quality analyses will be interpreted by geologic units. Water-quality samples collected in fiscal years 1989 and 1990 and wells and springs inventoried in fiscal years 1989 and 1990 will be included in the project report. Precipitation in relation to water-level changes in shallow wells will be considered to estimate annual recharge. Base-flow results will be evaluated to determine the ground water and surface water relations along Grass Creek and water-quality changes. The project report will be completed and submitted for approval.

PROJECT TITLE: Determination of long-term atmospheric deposition quality and climatic changes in the Western United States using continuous ice cores, Wind River Range, Wyoming (WY 90-120)

FUNDING AGENCY: Wyoming Water Development Commission, Northern Arapaho Tribe, Shoshone Tribe, and USGS

PROJECT LEADER: David L. Naftz

FIELD LOCATION: Northwestern Wyoming

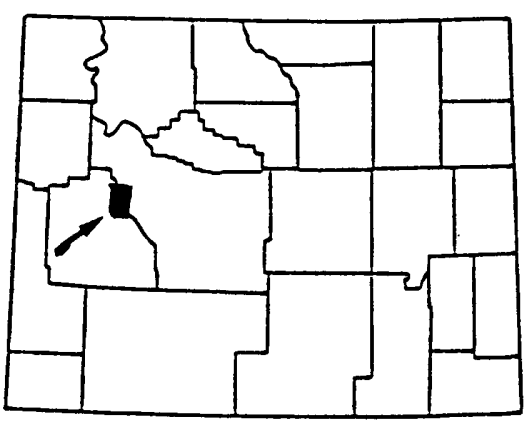

PERIOD OF PROJECT: February 1990 through September 1992

PROBLEM: There are many indications that climate is changing as a result of increasing concentrations of carbon dioxide and other trace gases in the atmosphere. The magnitude and rate of change are subject to question because of a lack of data. Long-term records of the chemical quality of atmospheric deposition and climate data are needed to make decisions regarding the effects of anthropogenic inputs to the atmosphere and climatechange issues. A long-term record of atmospheric deposition appears likely to be preserved as glacial ice layers in the Wind River Range of Wyoming.

OBJECTIVE: To use variations in concentrations of chemical and isotopic constituents from ice and tree-ring samples to reconstruct long-term records of the chemical quality of atmospheric deposition, as well as long-term climatic and discharge records. 
APPROACH: Continuous ice cores will be obtained from the surface to bedrock from selected glaciers in the Wind River Range. The samples will be dated using a combination of chemical and stratigraphic techniques. Major, minor, and trace chemical constituents will be determined in detailed subsamples of the core. Correlations between selected chemical constituents in the ice will be used to extend the period of record at the National Atmospheric Deposition Program site near Pinedale. Stable isotopes will be used to investigate long-term climate records in the ice. If possible, attempts will be made to use ice-core properties to extend the discharge records at established gaging stations back in time using time-series analysis.

PROGRESS AND SIGNIFICANT RESULTS: Upper Fremont Glacier in the Wind River Range of Wyoming was selected as the project study site based on reconnaissance-phase results from Knife Point Glacier (1988) and initial findings from Gannett Glacier (1989). Data collection on Upper Fremont Glacier was initiated in April 1990 with the excavation of three snow pits. Samples collected at these sites are being analyzed to determine major-ion concentrations, oxygen-18/oxygen-16 ratios, tritium levels, and particle counts, as well as $\mathrm{pH}$ and specific conductance. Snow stratigraphy and density and temperature profiles were noted in each pit. Also, probings along lateral and longitudinal traverses of the glacier were made to determine snow-pack depth. The above sampling protocol was repeated in July 1990 so that chemical and physical changes in the snowpack could be documented. Tree cores were taken near timberline in the North Fork Bull Lake Creek drainage. Radioecho soundings of the glacier were completed and these data are in the process of being reduced and complled. Ablation and velocity stakes were installed so the dynamics of the glacier might be better understood. Surveys of these points, as well as the sounding locations, were conducted from benchmarks established in July 1990. Benchmark "ICE-1" was located by a survey technique using satellites. An additional survey of the ablation and velocity stakes was made in September 1990. Ice-temperature thermistors were installed at depth at two sites. An automated meteorological station was installed in July 1990 and serviced in August 1990. Site-specific temperature, relative humidity, solar radiation, and wind direction and speed are being recorded hourly. Discharge measurements were made on North Fork Bull Lake Creek above Little Milky Lake in July 1990 and again in August 1990. Digital topographic coverage of the glacier and the vicinity has been generated.

PLANS FOR FISCAL YEAR 1991: Reduction and compilation of the chemical data will begin. Digital coverages of the surveys and other data will be completed and integrated to begin interpreting the dynamics of the glacier. Attempts to retrieve ice cores from depths greater that 15 meters below the glacier surface will be made. Chemical analyses of the ice will be initiated using the protocol already outlined. Monitoring of the chemical and physical properties of the snowpack will continue. Additional surveys of the ablation and velocity stakes will be completed. Operation of the meteorological station will continue, and data from the station will be reduced and compiled for analys is of the local weather environment. Additional discharge will be measured on North Fork Bull Lake Creek. 
PROJECT TITLE: Quantification of seepage and sedimentation in selected irrigation canals on the Wind River Indian Reservation, Wyoming (WY 90-121)

FUNDING AGENCY: Northern Arapaho and Shoshone Tribes and USGS

PROJECT LEADER: Kirk A. Miller

FIELD LOCATION: Fremont County, Wyoming

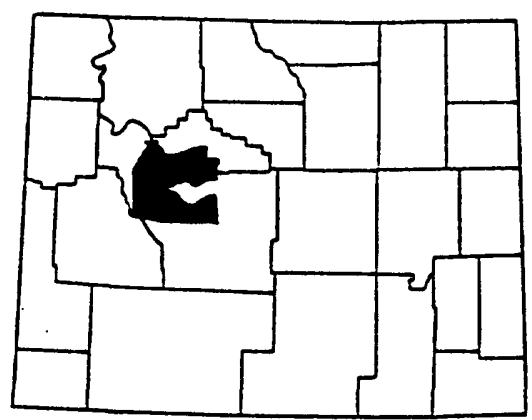

PERIOD OF PROJECT: March 1990 through September 1992

PROBLEM: Irrigation on the Wind River Indian Reservation occurs mostly on lands within the Wind River Indian Federal Irrigation Project (WRFIP) area. A major water management concern to the Shoshone and Arapaho Tribes, U.S. Bureau of Indian Affairs (BIA) and other water users in the Wind River basin is the seepage losses from the main canals. Reducing seepage losses would provide additional water for the irrigated lands, future expansion of irrigated lands, and for the downstream users. Sedimentation of the canals is another major water management problem. The accumulation of sediment reduces the conveyance capacity and efficiency of the canal and requires costly dredging operations.

OBJECTIVE: (1) To determine the magnitude and time distribution of seepage in selected canal reaches that have been identified as problem areas or are in representative surficial deposits within the WRFIP area; and (2) to determine the transverse distribution of the fluvial-sediment load in the reach upstream from selected diversion structures and the percentage of the sediment load entering canals.

APPROACH: Four canal reaches identified as either known seepage problem areas or on representative surficial deposits or both will be selected. Various stream diversion structures will be investigated, and three sediment study sites will be selected. Pre-irrigation site conditions including canal dimensions and surficial-material properties will be established for each canal reach. Three inflow-outflow seepage runs will be conducted on each canal reach during the irrigation season. Adjacent ground-water levels will be monitored. Three suspended-sediment and bedload samples will be taken from streams just above selected diversion structures and in canals near the same diversion point.

PROGRESS AND SIGNIFICANT RESULTS: Study reaches were selected for the seepage element of the investigation. Continuous-stage recorders were installed at both ends of the reaches to document steady-flow conditions. Discharge measurements were made at both ends and at intermediate points where necessary. Three sets of discharge measurements were made for two study reaches on Ray Canal. Two sets of discharge measurements were made for the study reaches on Dinwoody and Dry Creek Canals. Study sites were selected for the sediment element of the investigation. Suspended-sediment and bedload samples were collected in the river or creek directly upstream of the diversion. Transverse distribution of the sediment load will be determined in the river or creek. Suspended-sediment and bedioad samples 
were collected in the canal. Three sets of sediment samples were collected at the Wind River and Johnstown Canal study site. Two sets of sediment samples were collected at the Dry Creek and Dry Creek Canal study site. One set of sediment samples was collected at the Little Wind River and Subagency Canal study site.

PLANS FOR FISCAL YEAR 1991: One additional set of discharge measurements will be made on the Dinwoody Canal (recorder failure, early August) and the Dry Creek Canal (unsteady flows, late May) study reaches. Physical properties of soil samples from the study reaches will be investigated. One set of sediment samples from the Dry Creek and Dry Creek Canal site will be collected. Two sets of sediment samples will be collected at the Little Wind River and Subagency Canal site (sediment deposition in Subagency Canal might occur in "pulses" associated with gate changes at the headworks early in the season). Sediment samples will be processed. A report summarizing the study and data compilation will be ready for colleague review by July 1991. The published report will be completed by March 1992.

PROJECT TITLE: Hydrologic characteristics in fractured-rock aquifer, Rock Springs, Wyoming (WY 90-122)

FUNDING AGENCY: USGS

PROJECT LEADER: Kathy Muller Ogle

FIELD LOCATION: ROck Springs, Wyoming

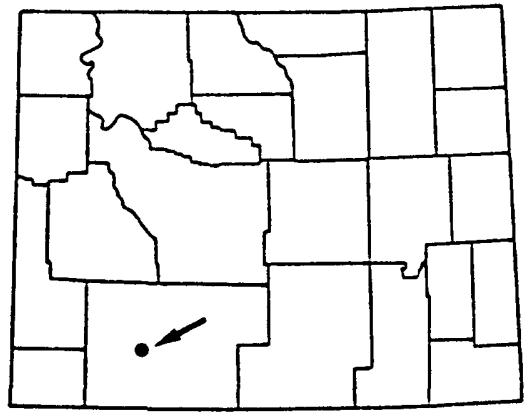

PERIOD OF PROJECT: March 1990 through September 1991

PROBLEM: A 1976 in-situ oil-shale retorting experiment produced 150 distinct organic and inorganic contaminants at a site near Rock Springs in southwestern Wyoming, according to previous studies by the U.S. Department of Energy and USGS. The site provides an opportunity to study ground-water movement in a fractured shale aquifer and the transport and fate of contaminants. Funding to study these processes has been applied for through the toxic waste ground-water contamination program. The first phase of the study (this project) will be to define the ground-water flow system.

OBJECTIVE: (1) Determine whether the flow system is static or dynamic;

(2) determine major mechanism affecting flow and transport at the site; and

(3) plan future studies concerning contaminant transport.

APPROACH: Continue monitoring water levels in all wells (fluctuations in water table would be a good indicator of a dynamic flow system). Continue quantitative analysis of existing data to assess the role of the sandstone layer in contaminant transport, and analyze data on distribution of contaminants during 1989 to determine contaminant transport in the aquifer. 
PROGRESS AND SIGNIFICANT RESULTS: The White Mountain in-situ oil-shale site near Rock Springs was evaluated to determine suitability as a site for additional research on toxic contaminants in a fractured-flow aquifer. Data from previous studies at the site were compiled, and 117 new water-level measurements were made. Analysis of the data indicated that (1) there is evidence of fractures at the site, (2) there is evidence of fracture flow, (3) the system is dynamic, and (4) the data are too limited to define the hydrologic function of the 8-foot sandstone layer. A sumary of the findings was prepared and sent to the coordinator of the USGS Toxics Research Program.

PLANS FOR FISCAL YEAR 1991: A short report on the findings will be prepared, as well as a brief paper for a meeting in 1991 on USGS toxics research. All research has stopped because of loss of funding.

PROJECT TITLE: Assessment of the current collection of basic records sediment data base (WY 90-123)

FUNDING AGENCY: USGS

PROJECT LEADER: James G. Rank1

FIELD LOCATION: TOpical research

PERIOD OF PROJECT: February 1990 through September 1992

PROBLEM: The USGS is reviewing sediment data collection and processing to determine program strengths and weaknesses. Emphasis is being placed on evaluation of the existing sediment data base and how sampling procedures can be modified to provide better sediment information for determining frequency distributions of loads and concentrations by size.

OBJECTIVE: To conduct a thorough assessment of Collection of Basic Records (CBR) daily sediment data sets focusing on: (1) the suitability of the data, by particle-size ranges, to be described by transport curves or other models; (2) the range of flow conditions sampled; frequency distribution of mean-daily concentrations and daily, monthly, and annual loads; and frequency distribution of daily concentrations for each month; (3) the representativeness of $c$ limate and runoff conditions during the period of record, and the detection of trends in transport rates during the period of record; and (4) the quality of the record, including the adequacy of sampled concentrations.

APPROACH: (1) Review literature concerning sediment-related studies on data collected at the CBR sediment stations and sediment stations in Canada; (2) working with the USGS Branch of Systems Analysis, develop methods for evaluating sediment records for daily sediment stations; (3) test these methods on 2 of the 12 daily CBR sediment stations; (4) based on results of 
the tests at these two stations, develop a detailed work plan for evaluating all the daily CBR sediment stations; and (5) present the work plan and results to the Sediment Action Committee, Office of Surface Water, and Office of the Assistant Chief Hydrologist for Operations.

PROGRESS AND SIGNIFICANT RESULTS: The approach used in the study was to determine how much reduction in uncertainty can be obtained from a given number of suspended-sediment measurements. The uncertainty in the estimates of the transport is the mean square error of the difference between the estimated suspended-sediment load and the true suspended-sediment load. The estimated load was computed from a model of the discharge rating curve developed from the engineer samples, and the true load was taken as the load determined from daily samples collected by the observers, type curves, and the hydrographer's judgment in drawing the dajly-concentration curve. Several models, based on the logarithmic transforms of sediment and water discharge, were tested to determine which model had the minimum error in estimating the observer samples. Ten years of sediment and discharge data for the Yadkin River at Yadkin College, North Carolina and the Pecos River near Artesia, New Mexico were used in the analysis. The residuals for each station were analyzed as a time series to estimate lag-one-day autocorrelation coefficient, the process variance, and the measurement variance. These three parameters were used in a lognormal regression model to obtain the standard error of estimate of the total transport as a function of the number of measurements made at the site per year. Uncertainty curves were generated for both stations. Based on the uncertainty curves, there are now some measures of how much uncertainty there would be at the two stations for different sampling frequencies. Basically, daily sampling achieved a 10-percent reduction in the root mean square error, compared with monthly sampling for the two stations.

PLANS FOR FISCAL YEAR 1991: Work discontinued because of loss of funding.

PROJECT TITLE: Water resources of Fremont County, Wyoming (WY 90-124)

FUNDING AGENCY: Wyoming State Engineer and USGS

PROJECT LEADER: Maria Plafcan

FIELD LOCATION: Central Wyoming

PERIOD OF PROJECT: March 1990 through September 1993

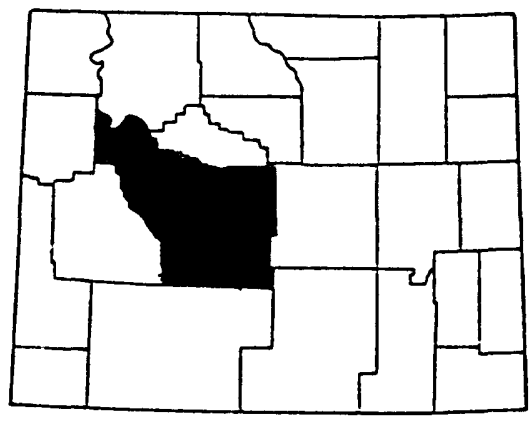

PROBLEM: Ground water of poor chemical quality has long been a problem for residents in Fremont County. Demand for water suitable for domestic and municipal supply has increased as previous supplies have become unsatisfactory because of yield or water quality. Water quality and the potential yield of aquifers currently not used need to be investigated to aid county planners. 
OBJECTIVE: (1) To describe the geohydrologic conditions in the county; (2) to determine the general occurrence and chemical quality of ground water; and (3) to describe the availability of ground water and areas of potential contamination.

APPROACH: Representative wells and springs will be inventoried and specific conductance of ground water and base flow will be measured. Samples of ground water will be collected and analyzed for dissolved constituents. Some ground-water samples will be analyzed to determine if specific contaminants are in the water. Low-flow gains and losses along selected reaches of the Wind River and tributaries will be measured at specific geologic formations to estimate recharge and discharge. Based on the study, observation wells will be suggested for potential long-term monitoring.

PROGRESS AND SIGNIFICANT RESULTS: All ground-water and water-quality information in the data base was checked against the well schedules and plotted on 7.5-minute maps. This information was used for selecting sites to sample during the summer of 1990. Seventy-seven ground-water sites were visited, and data were collected for 44 new sites and 7 existing sites. Forty water samples were collected for analysis of common cations and anions. Discharges were measured at a number of springs. All data were entered into the data base. Preliminary data from U.S. Bureau of Land Management have been gathered to enhance site choices for summer 1991 onsite work. Current work includes digitizing a base map of the county for the project report to develop plots to aid in the analysis of water-quality and geologic variables. Previously collected data also are being used to facilitate writing the geology, climate, hydrologic-characteristics, and land-use sections of the report. Data are being compiled and entered into a data base from a 1959 publication on ground-water resources of the Riverton Irrigation Project Area and will be analyzed statistically to provide a perspective in selecting 1991 summer sampling sites on Irrigation Project land, as well as to develop quality-assurance procedures for existing data.

PLANS FOR FISCAL YEAR 1991: Work to be completed includes ground-water and water-quality data collection and analyses for standard cations and anions, selected pesticides, and metals. Low-flow data also may be collected. For site selection, other Federal and State agencies will be contacted concerning their samplings and findings. Selected sections of the project report, as well as initial water-quality tables, also will be completed in the fiscal year.

PROJECT TITLE: Preparation of U.S. Department of the Interior environmental impact statement on operation of Glen Canyon Dam, Arizona (WY 91-125)

FUNDING AGENCY: USGS

PROJECT LEADER: James F. Wilson, Jr. FIELD LOCATION: Administrative

PERIOD OF PROJECT: February 1991 through June 1993 
PROBLEM: The Secretary of the Interior has directed that an Environmental Impact Statement (EIS) be prepared on the effects of operation of Glen Canyon Dam on the aquatic and riparian resources of the Colorado River downstream in Glen Canyon and Grand Canyon National Park. Sediment transported and deposited in the river is the foundation for biological and recreational resources, such as fish habitat, whitewater rapids, and camping beaches. The dam traps about 80 percent of the annual sediment load that formerly entered the canyon; there is concern about the long-term net loss of sediment. Patterns of water releases from the dam for power generation exacerbate the problem. Concurrently with preparation of the EIS, extensive research is being done; the USGS is involved in hydrologic and hydraulic studies that will provide useful information for the EIS.

OBJECTIVE: To serve as the USGS representative on the interagency EIS Team, led by the U.S. Bureau of Reclamation, including preparation of sections of the EIS having to do with sediment-related topics.

APPROACH: Principal activities will include: (1) familiarization with past and ongoing USGS sediment-related research in the Colorado River in the Grand Canyon and adjacent areas; (2) liaison between the EIS team and the scientists of the Water Resources Division (WRD) National Research Program and Arizona District; (3) participation in all EIS team functions, including public hearings; (4) preparation of the fluvial-sediment sections of the draft and final EIS.

PLANS FOR FISCAL YEAR 1991: First-year activities will include: (1) contacts with USGS hydrologists to become familiar with current related research; (2) gathering and studying scientific literature; (3) attending EIS Team meetings; (4) attending public hearings on the proposed operational

alternatives to be assessed; and (5) preparation of preliminary rough drafts of the sediment sections of the EIS.

PROJECT TITLE: Characterization of water resources in Teton County, Wyoming (WY 91-126)

FUNDING AGENCY: Northern Arapaho Tribe, Shoshone Tribe, and USGS

PROJECT LEADER: Bernard T. Nolan

FIELD LOCATION: Northwestern Wyoming

PERIOD OF PROJECT: March 1991 through December 1994

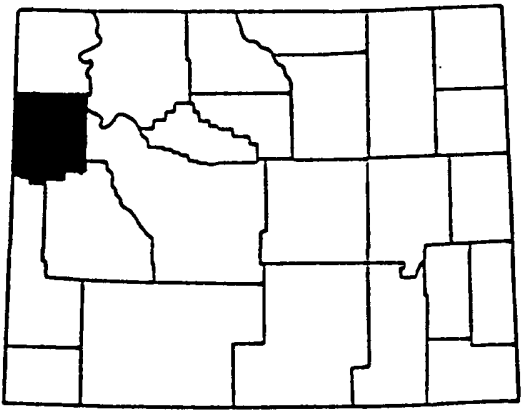

PROBLEM: Collection and interpretation of ground-and surface-water data are necessary to characterize thoroughly the water resources of Teton County. Land-use planners lack detailed information about the water resources of the county. Increased development in the Snake River basin has increased the potential for changes in water quantity and quality. Lack of understanding of land-use effects on water resources could result in unnecessary depletion or degradation of water both in developed and in pristine areas. 
OBJECTIVE: (1) To determine the current condition of water resources in the county; (2) to identify land uses capable of affecting water quantity and quality in developed areas; (3) to evaluate the availability of ground and surface water and the spatial distribution of water-quality constituents; and (4) to determine future ground- and surface-water monitoring requirements.

APPROACH: The technical approach is: (1) to determine prior conditions by reviewing information in USGS data bases (year 1 of study); (2) to identify major land uses and potential effects on water quantity and quality (year 1); (3) to characterize current conditions by conducting a representative, county-wide survey (years 1-3); and (4) to determine the statistical distribution of the data with histograms and fractile analysis (years 2-3).

PLANS FOR FISCAL YEAR 1991: (1) Wells, springs, and streams will be selected for water-level and flow measurements and water-quality sampling;

(2) permission will be obtained from their owners to sample wells; and (3) onsite samples will be collected.

PROJECT TITLE: Evaluation of potential causes of water-quality changes in major streams in Owl Creek basin, wyoming (WY 91-127)

FUNDING AGENCY: Northern Arapaho Tribe and USGS

PROJECT LEADER: Kathy Muller Ogle

FIELD LOCATION: North-central Wyoming

PERIOD OF PROJECT: April 1991 through December 1993

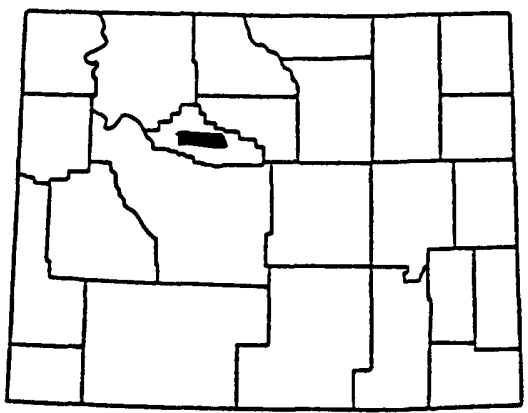

PROBLEM: A recent investigation in the Owl Creek basin concluded that the quality of the major streams in the basin degraded significantly in the downstream direction. The watershed reflected three distinct segments, each having significantly different dissolved-solids concentration, water type, and dissolved solids to specific conductance ratio. However, the causes of these changes are unknown. Possible causes have been identified as irrigation return flows, surface geology, and ground-water inflow from various aquifers.

OBJECTIVE: To determine the changes in water quality and the human-induced and naturally occurring causes of changes in water quality of the major streams in the Owl Creek basin.

APPROACH: Changes in water quality and possible causes of these changes in Owl Creek basin will be examined in the two areas where water-quality changes were observed in the previous study. Onsite parameters, major ions, selected metals, and isotopes will be sampled at selected sites in those two areas. Streamflow measurements will be made concurrentiy. The water- 
quality and streamflow data will be compared to changes in land use, surface geology, geologic structures, and data from aquifers in the area to determine the causes of the changes in water quality.

PLANS FOR FISCAL YEAR 1991: Project planning will be completed and data gathering activities will be initiated.

PROJECT TITLE: Estimates of monthly streamflow characteristics for ungaged sites, Wind River Indian Reservation, Wyoming (WY 91-128)

FUNDING AGENCY: Northern Arapaho Tribe, Shoshone Tribe, and USGS

PROJECT LEADER: James G. Rank 1

FIELD LOCATION: Central Wyoming

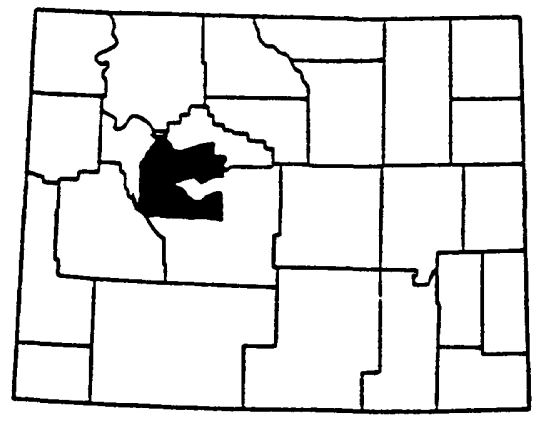

PERIOD OF PROJECT: October 1990 through September 1993

PROBLEM: Following a 12-year legal action, the U.S. Supreme Court in 1989 awarded 500,000 acre-feet per year of surface water on the Wind River and its tributaries to the Arapaho and Shoshone Indian Tribes. Planning and management of these waters make accurate data important. However, only a few of the stream sites where data are needed have streamflow-gaging stations. Questions that arise during management of surface-water allocations involve (1) the quantity of runoff that originates on the Reservation, and (2) the magnitudes of monthly and mean-annual flows in streams entering and leaving the Reservation.

OBJECTIVE: A refined technique for estimating mean monthly and annual streamflows will be developed, and streamflows at selected sites will be estimated to assist the Wind River Environmental Quality Council in the development of a streamflow management model.

APPROACH: About 20 ungaged sites will be selected for estimation of mean monthly and annual discharge along with about 10 gaged sites for control. Monthly measurements will be made for 1 year. Three methods will be investigated: (1) instantaneous discharge will be correlated to monthly mean discharge at nearby gaged sites using regression equations; (2) a set of mean monthly discharge estimates will be made from regression equations relating mean monthly discharge to physical and climatic variables; and (3) a set of mean monthly discharge estimates will be made from regression equations using channel width. The final estimate will be a weighted average of methods that are statistically significant.

PLANS FOR FISCAL YEAR 1991: The streams that will be used in the study will be selected, staff gages installed, levels run, and monthly measurements made at all sites. An annotated outline will be prepared. 
PROJECT TITLE: Sumary and evaluation of well and geologic data for pre-Tertiary aquifers on the Wind River Indian Reservation, Wyoming (WY 91-129)

FUNDING AGENCY: Northern Arapaho Tribe, Shoshone Tribe, and USGS

PROJECT LEADER: J.B. Lindner-Lunsford

FIELD LOCATION: Central Wyoming

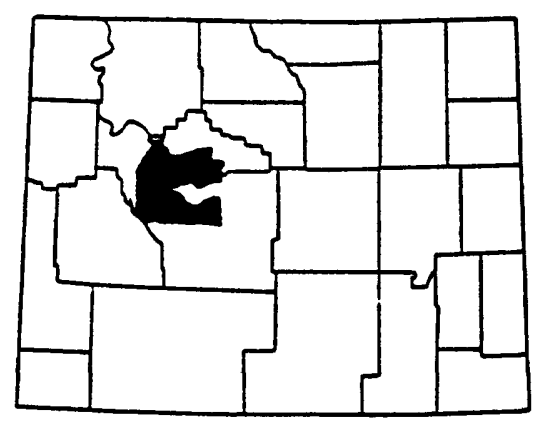

PERIOD OF PROJECT: April 1991 through September 1992

PROBLEM: Information is needed to define and to evaluate new sources of ground-water supplies on the Wind River Indian Reservation for future population growth and economic development.

OBJECTIVE: (1) Provide ground-water information on total dissolved-solids concentrations, expressed as sodium chloride ( $\mathrm{NaCl}$ ) for aquifers having a potential to yield more than 500 gallons per minute to wells; and (2) provide information on well locations and depths for aquifers identified in objective (1) as having total dissolved solids (as $\mathrm{NaCl}$ ) less than 1,000 milligrams per liter.

APPROACH: Calibrated geophysical logs for 0il-and-gas wells will be the primary source of data. A straight-line correlation between resistivity and total dissolved solids (as $\mathrm{NaCl}$ ) will be applied.

PLANS FOR FISCAL YEAR 1991: Resistivity logs for about 400 wells will be acquired, and preliminary data analysis started.

PROJECTS COMPLETED DURING FISCAL YEARS 1990 AND 1991

Project number

WY 81-060

WY $82-072$

WY 86-098

\section{Project title}

Ground-water hydrology of the southern Powder River Uranium District, Wyoming

Stream-aquifer interaction in the upper Bear River valley of Wyoming and Utah

Assessment of selenium concentrations in soils, sediments, and water; Sandstone Reservoir

Project, Carbon County, Wyoming

\section{Project leader}

Marlin E. Lowry

Kent C. Glover

David L. Naftz 

WY 86-099
Summary and assessment of
investigations for evaluating the
James F. Wilson, Jr.
effects of coal development on
ground-water resources in the Powder
River basin, northeastern Wyoming
WY $87-102$
Water resources of Washakie County. Wyoming
WY 88-106
Field screening study of water quality, bottom sediments, and biota of the Riverton Irrigation Project, Fremont County, Wyoming
WY $88-110$
A geographic information system for evaluating potential disturbance of bald eagles by recreational use of the Snake River in Grand Teton National Park, Wyoming
WY 88-112
Sediment transport of streams in the James G. Rankl Sierra Madre,-Wyoming
David D. Susong
David A. Peterson
James F. Wilson, Jr.
PROJECTS COMPLETED EXCEPT FOR REPORT(S)

The following projects, with project number, title, and leader, have been completed except for approval of the final report(s). Funding for these projects ended prior to fiscal year 1990.

Project number

WY $82-070$

WY 83-076

WY 84-081

WY 85-091

WY $87-103$

WY $88-114$
Project title

Upper Colorado River basin Regional Aquifer-System Analysis, Wyoming

Fluvial system in energy-mineral areas of Wyoming

Water resources of Park County, Wyoming

Geohydrology of the High Plains Aquifer, Cheyenne, Wyoming

Water resources of Big Horn County, Wyoming

Quality of surface water and ground water in the Owl Creek basin, Wind River Indian Reservation, Wyoming
Project leader

Lawrence J. Martin and W.B. Borchert

Hugh W. Lowham

Marlin E. Lowry and W.B. Borchert

Marvin A. Crist

Maria Plafcan and Earl W. Cassidy

Kathy Muller Ogle 


\section{WATER-RESOURCES INFORMATION}

A monthly summary of the national water situation is presented in the newsletter National Water Conditions, available free upon request to the Hydrologic Information Unit, USGS, 419 National Center, Reston, VA 22092. Requests for miscellaneous water information and information about programs in other states may be referred to Water Resources Division, USGS, 440 National Center, Reston, VA 22092. Streamflow, ground-water, and water-quality data are available in several series of publications.

\section{Hydrologic Data Prior to 1971}

Records of streamflow, ground-water levels, and quality of water were published for many years as U.S. Geological Survey (USGS) Water-Supply Papers, as explained below. The Water-supply Papers are not listed in this report; information about them can be obtained from the USGS office in Cheyenne.

Records of daily flows of streams prior to 1971 were published in the Water-Supply Paper series, "Surface-Water Supply of the United States," which was released in numbered parts as determined by natural drainage basins. Data for Wyoming are published in Parts 6, 9, 10, and 13. Until 1961, this was an annual series; monthly and yearly summaries of these data were compiled in two reports: "Compilation of Records of Surface Waters of the United States through September 1950," and "Compilation of Records of Surface Waters of the United States, October 1950 to September 1960." A 5-year compilation was published for 1965-70.

Ground-water levels and artesian pressures in observation wells prior to 1975 were reported by geographic areas in a 5-year Water-Supply Paper series. Data for Wyoming are in "Ground-Water Levels in the United States, Northwestern States."

Surface-water-quality data prior to 1971 were published annually in the Water-Supply Paper series "Quality of Surface Waters of the United States," which also was released in numbered parts as determined by natural drainage basins. Data for Wyoming are in Parts $6,9,10$, and 13 .

\section{Hydrologic Data After 1970}

Beginning with water year 1971, the aforementioned Water-Supply Paper series was replaced by a new publication series, U.S. Geological Survey WaterData Reports. For water years 1971-74, surface-water records and waterquality records were published in separate volumes. Beginning with 1975, this series combines under one cover: streamflow data, water-quality data for surface and ground water, and ground-water-level data for each state. For Wyoming, the title is "Water Resources Data, Wyoming--Water Year (date)." Since 1975 the reports are numbered: "U.S. Geological Survey Water-Data Report WY-(year)-1 or 2"; reports for 1971-74 are unnumbered. These reports are listed in a subsequent section of this report. 


\section{Flood Information}

Methods for estimating the magnitude and frequency of floods for streams in Wyoming are given in Water-Resources Investigations Report 88-4045; methods for estimating flood volumes and hydrographs on small plains streams are described in Water-Supply Paper 2056 (see listings that follow). The USGS also has outlined flood-prone areas on topographic maps as part of a nationwide Federal program for managing flood losses. In Wyoming 225 floodprone area maps have been completed. These maps, available at no charge from the District office in Cheyenne, show areas estimated to be inundated by a 100 -year flood. Official flood-insurance maps are available from the Federal Emergency Management Agency (toll-free phone number 1-800-638-6620).

\section{SELECTED PUBLICATIONS ON WATER RESOURCES}

\section{General Information}

The USGS announces all its publications in a monthly report, "New Publications of the USGS." Subscription to this monthly listing is available free upon request to the Mailing List Unit, USGS, 582 National Center, Reston, VA 22092. All publications are for sale unless specifically stated otherwise; prepayment is required. Checks or money orders should be payable to: "U.S. Department of the Interior--USGS." Prices, which are subject to change, are not included here. Information on price and availability should be obtained from listed sales offices before placing an order.

Additional information about USGS products and sources where they may be obtained is given in "A Guide to Obtaining USGS Information," U.S. Geological Survey Circular 900, available without cost from the Books and Open-File Reports Section, USGS, Federal Center, Box 25425, Denver, CO 80225.

The USGS maintains a library with an extensive earth-sciences collection. Local libraries may obtain books, periodicals, and maps through interlibrary loan by writing to USGS Library, 950 National Center, Reston, VA 22092, telephone (703) 860-6671.

Publications pertaining to water resources in Wyoming are listed as follows. The list includes all reports published during the last 15 years and selected older reports. Most of these reports are available for inspection at the USGS offices in Cheyenne, Casper, and Riverton and also at large public and university libraries. The sources for obtaining copies of the reports are given for each report series. Because many of the older reports are out of print, loan copies are available from the District office in Cheyenne.

\section{Professional Papers (P)}

Professional papers are sold by USGS, Books and Open-File Reports Section, Box 25425, Federal Center, Denver, CO 80225. 
$P$ 501-D. Variation of permeability in the Tensleep Sandstone in the Bighorn basin, Wyoming, as interpreted from core analyses and geophysical logs, by J.D. Bredehoeft, in Geological Survey Research 1964, Chap. D, by U.S. Geological Survey, p. D166-D170. 1964.

P 550-D. The White River Formation as an aquifer in southeastern Wyoming and adjacent parts of Nebraska and Colorado, by M.E. Lowry, in Geological Survey Research 1966, Chap. D, by U.S. Geological Survey, p. D217-D222. 1966.

P 622-A. The hydraulics of overland flow on hillslopes, by W.W. Emmett. 1970.

P 700-D. Synthesizing hydrographs for small semiarid drainage basins, by G.S. Craig, Jr., in Geological Survey Research 1970, Chap. D, by U.S. Geological Survey, p. D238-D243. 1970.

$P$ 1117. Scour and fill in a stream channel, East Fork River, western Wyoming, by E.D. Andrews. 1979.

P 1130. Hydrologic and human aspects of the 1976-77 drought, by H.F. Matthai. 1979.

$P$ 1164. Effects of coal mine subsidence in the Sheridan, Wyoming area, by C.R. Dunrud and F.W. Osterwald. 1980.

$P$ 1242. Perennial-streamflow characteristics related to channel geometry and sediment in the Missouri River basin, by W.R. Osterkamp and E.R. Hedman. 1982.

P 1244. Floods of May 1978 in southeastern Montana and northeastern Wyoming, by Charles Parrett, D.D. Carlson, G.S. Craig, Jr., and E.H. Chin.

P 1273-A. Stratigraphy and sedimentary facies of the Madison Limestone and associated rocks in parts of Montana, Nebraska, North Dakota, South Dakota, and Wyoming, by J.A. Peterson. 1984.

P 1273-B. Correlation of paleostructure and sediment deposition in the Madison Limestone and associated rocks in parts of Montana, North Dakota, South Dakota, Wyoming, and Nebraska, by D.L. Brown, R.K. Blankennage1, L.M. MacCary, and J.A. Peterson. 1984.

$P$ 1273-C. Relationship of porosity and permeability to petrology of the Madison Limestone in rock cores from three test wells in Montana and Wyoming, by P.A. Thayer. 1983.

P 1273-D. Apparent water resistivity, porosity, and water temperature of the Madison Limestone and underlying rocks in parts of Montana, Nebraska, North Dakota, South Dakota, and Wyoming, by L.M. MacCary. 1984.

P 1273-E. Potentially favorable areas for large-yield wells in the Red River Formation and Madison Limestone in parts of Montana, North Dakota, South Dakota, and Wyoming, by L.M. MacCary, E.M. Cushing, and D.L. Brown. 1983. 
P 1273-G. Geohydrology of the Madison and associated aquifers in parts of Montana, North Dakota, South Dakota, and Wyoming, by J.S. Downey. 1984.

P 1277-A. Hydrologic and morphologic changes in channels of the Platte River basin in Colorado, Wyoming, and Nebraska; a historical perspective, by H.R. Eschner, R.F. Hadley, and K.D. Crowley. 1983.

P 1277-B. Effects of water development on surface-water hydrology, Platte River basin in Colorado, Wyoming, and Nebraska upstream from Duncan, Nebraska, by J.E. Kircher, and M.R. Karlinger. 1983.

P 1273-F. Geochemical evolution of water in the Madison aquifer in parts of Montana, South Dakota, and Wyoming, by J.F. Busby, L.N. Plummer, R.W. Lee, and B.B. Hanshaw. 1991 .

$P$ 1330. A seismic-stratigraphic investigation of the Madison and associated aquifers; application to ground-water exploration, Powder River basin, Montana-Wyoming, edited by A.H. Balch. 1988.

$P$ 1338. Effects of organic wastes on water quality from the processing of oil shale from the Green River Formation, Colorado, Utah, and Wyoming, by J.A. Leenheer and T.I. Noyes. 1986.

P 1400-A. Summary of the High Plains Regional Aquifer-System Analysis in parts of Colorado, Kansas, Nebraska, New Mexico, South Dakota, Texas, Oklahoma, and Wyoming, by J.B. Weeks, E.D. Gutentag, F.J. Heimes, and R.R. Luckey. 1988.

P 1400-B. Geohydrology of the High Plains aquifer in parts of Colorado, Kansas, Nebraska, New Mexico, Oklahoma, South Dakota, Texas, and Wyoming, by E.D. Gutentag, F.J. Heimes, N.C. Krothe, R.R. Luckey, and J.B. Weeks. 1984 .

P 1400-C. Mapping irrigated cropland from Landsat for determination of wateruse from the High Plains aquifer in parts of Colorado, Kansas, Nebraska, New Mexico, Oklahoma, South Dakota, Texas, and Wyoming, by G.P. Thel in and F.J. Heimes. 1987.

P 1400-0. Digital simulation of ground-water flow in the High Plains aquifer in parts of Colorado, Kansas, Nebraska, New Mexico, Oklahoma, South Dakota, Texas, and Wyoming, by R.R. Luckey, E.D. Gutentag, F.J. Heimes, and J.B. Weeks. 1986.

P 1400-E. Effects of future ground-water pumpage on the High Plains aquifer in parts of Colorado, Kansas, Nebraska, New Mexico, Oklahoma, South Dakota, Texas, and Wyoming, by R.R. Luckey, E.D. Gutentag, F.J. Heimes, and J.B. Weeks. 1988.

$P$ 1402-A. The regional aquifer system underlying the Northern Great Plains in parts of Montana, North Dakota, South Dakota, and Wyoming--Summary, by J.S. Downey and G.A. Dinwiddie. 1988. 
P 1402-B. Geologic framework of the ground-water system in Jurassic and Cretaceous rocks in the Northern Great Plains in parts of Montana, North Dakota, South Dakota, and Wyoming, by L.0. Anna. 1986.

P 1402-C. Geochemistry of ground water in two sandstone aquifer systems in the Northern Great Plains in parts of Montana and Wyoming, by Thomas Henderson. 1985.

$P$ 1402-D. Freshwater heads and ground-water temperatures in aquifers of the Northern Great Plains in parts of Montana, North Dakota, South Dakota, and Wyoming, by D.H. Lobmeyer. 1985.

P 1402-E. Geohydrology of bedrock aquifers in the Northern Great Plains in parts of Montana, North Dakota, South Dakota, and Wyoming, by J.S. Downey. 1986 .

P 1411-C. Geohydrology of Mesozoic rocks in the upper Colorado River basin-excluding the San Juan basin--in Arizona, Colorado, Utah, and Wyoming, by G.W. Freethey and G.E. Cordy. In press.

P 1464. Summary of the USGS and U.S. Bureau of Land Management national coalhydrology program, 1974-84, edited by L.J. Britton, C.L. Anderson, D.A. Goolsby, and B.P. Van Haveren. 1989.

\section{Journal of Research of the Geological Survey}

The Journal of Research Series has been discontinued. Separate prints of the articles listed below are available from the District Chief, Cheyenne, Wyoming.

Iron in water near wastewater lagoons in Yellowstone National Park, Wyoming, by E.R. Cox, v. 6, no. 3, p. 319-324. 1978.

Hydrologic characteristics of the Madison Limestone, the Minnelusa Formation, and equivalent rocks as determined by well-logging formation evaluation, Wyoming, Montana, South Dakota, and North Dakota, by W.J. Head and R.H. Merkel, v. 5, no. 4, p. 473-485. 1977.

\section{Water-Supply Papers (W)}

Water-Supply Papers are sold by USGS, Books and Open-File Reports Section, Box 25425, Federal Center, Denver, CO 80225.

W 1261. A postglacial chronology for some alluvial valleys in Wyoming, by L.B. Leopold and J.P. Miller. 1954.

W 1373. Sedimentation and chemical quality of surface waters in the Wind River basin, Wyoming, by B.R. Colby, C.H. Hembree, and F.H. Rainwater. 1956. 
W 1375. Ground-water resources of the Riverton irrigation project area, Wyoming, by D.A. Morris, O.M. Hackett, K.E. Vanlier, and E.A. Moulder, with a section on Chemical quality of ground water, by W.H. Durum. 1959.

W 1377. Geology and ground-water resources of Goshen County, Wyoming, by J.R. Rapp, F.N. Visher, and R.T. Littleton, with a section on Chemical quality of ground water, by W.H. Durum. 1957.

W 1458. Geology and ground-water resources of the Rawlins area, Carbon County, Wyoming, by D.W. Berry. 1960.

W 1490. Geology and ground-water resources of Platte County, Wyoming, by D.A. Morris and H.M. Babcock, with a section on Chemical quality of ground water, by R.H. Langford. 1960.

W 1531. Hydrology of the upper Cheyenne River basin: Part A. Hydrology of stock-water reservoirs in upper Cheyenne River basin, by R.C. Culler; Part B. Sediment sources and drainage-basin characteristics in upper Cheyenne River basin, by R.F. Hadley and S.A. Schumm. 1961.

W 1532-A. Hydrologic effects of water spreading in Box Creek basin, Wyoming, by R.F. Hadley, I.S. McQueen, and others. 1961.

W 1535-E. Chemical degradation on opposite flanks of the Wind River Range, Wyoming, by C.H. Hembree and F.H. Rainwater. 1961.

W 1539-V. Availability of ground water in the Bear River valley, Wyoming, by C.J. Robinove and D.W. Berry, with a section on Chemical quality of ground water, by J.G. Conner. 1963.

W 1576-I. Ground-water resources of the Wind River Indian Reservation, Wyoming, by L.J. McGreevy, W.G. Hodson, and S.J. Rucker, IV. 1969.

W 1596. Geology and ground-water resources of the Greybull River--Dry Creek area, Wyoming, by C.J. Robinove and R.H. Langford. 1963.

W 1669-E. Ground-water resources and geology of the Lyman-Mountain View area, Uinta County, Wyoming, by C.J. Robinove and T.R. Cummings. 1963.

W 1698. Ground-water resources and geology of northern and western Crook County, Wyoming, by H.A. Whitcomb and D.A. Morris, with a section on Chemical quality of the ground water, by R.H. Langford. 1964.

W 1788. Ground-water resources and geology of Niobrara County, Wyoming, by H.A. Whitcomb, with a section on Chemical quality of the ground water, by T.R. Cummings. 1965.

W 1806. Ground-water resources and geology of northern and central Johnson County, Wyoming, by H.A. Whitcomb, T.R. Cummings, and R.A. McCullough. 1966.

W 1807. Ground-water resources of Sheridan County, Wyoming, by M.E. Lowry and T.R. Cummings. 1966. 
W 1809-C. Ground water in the upper Star Valley, Wyoming, by E.H. Walker. 1965.

W 1834. Geology and ground-water resources of Laramie County, Wyoming, by M.E. Lowry and M.A. Crist, with a section on Chemical quality of ground water and of surface water, by J.R. Tilstra. 1967.

W 1897. Ground-water resources of Natrona County, Wyoming, by M.A. Crist and M.E. Lowry. 1972.

W 2009-C. Chemical quality of surface water in the Flaming Gorge Reservoir area, Wyoming and Utah, by R.J. Madison and K.M. Waddell. 1973.

W 2023. Selenium in waters in and adjacent to the Kendrick Project, Natrona County, Wyoming, by M.A. Crist. 1974 .

W 2039-A. Chemical quality and temperature of water in Flaming Gorge Reservoir, Wyoming and Utah, and the effects of the reservoir on the Green River, by E.L. Bolke and K.M. Waddell. 1975.

W 2056. Analysis of runoff from small drainage basins in Wyoming, by G.S. Craig, Jr. and J.G. Rankl. 1978.

W 2058. Dissolved-oxygen depletion and other effects of storing water in Flaming Gorge Reservoir, Wyoming and Utah, by E.L. Bolke. 1979.

W 2193. Streamflow characteristics related to channel geometry of streams in Western United States, by E.R. Hedman and W.R. Osterkamp. 1982.

W 2199. Verification of step-backwater computations on ephemeral streams in northeastern Wyoming, by S.A. Druse. 1982.

W 2250. National water summary 1983--Hydrologic events and issues, by U.S. Geological Survey. 1984.

W 2275. National water summary 1984--Hydrologic events, selected waterquality trends, and ground-water resources, by U.S. Geological Survey. 1985.

W 2289. Artesian pressures and water quality in Paleozoic aquifers in the Ten Sleep area of the Bighorn basin, north-central Wyoming, by M.E. Cooley. 1986.

W 2300. National water summary 1985--Hydrologic events and surface-water resources, by U.S. Geological Survey. 1986.

W 2322. Leachate migration from an in-situ oil-shale retort near Rock Springs, Wyoming, by K.C. Glover. 1988.

W 2325. National water summary 1986--Hydrologic events and ground-water quality, by U.S. Geological Survey. 1988. 
W 2350. National water summary 1987--Hydrologic events and water supply and use, by U.S. Geological Survey. 1990.

W 2358. Characteristics and trends of streamflow and dissolved solids in the upper Colorado River basin, Arizona, Colorado, New Mexico, Utah, and Wyoming, by T.D. Liebermann, D.K. Mueller, J.E. Kircher, and A.F. Choquette. 1989.

W 2366. A point-infiltration model for estimating runoff from rainfall on small basins in semiarid areas of Wyoming, by J.G. Rankl. 1990.

W 2375. National water summary 1988-89--Hydrologic events and floods and droughts, by U.S. Geological Survey. In press.

\section{Circulars (C)}

Single copies of circulars still in print are available free from USGS, Books and Open-File Reports Section, Box 25425, Federal Center, Denver, CO 80225 .

C 160. Sedimentation and chemical quality of water in the Powder River drainage basin, Wyoming and Montana, by C.H. Hembree, B.R. Colby, H.A. Swenson, and J.R. Davis. 1952.

C 743. Land and natural resource information and some potential environmental effects of surface mining of coal in the Gillette area, Wyoming, by W.R. Keefer and R.F. Hadiey. 1976.

C 839. Assessment of impacts of proposed coal-resource and related economic development on water resources, Yampa River basin, Colorado and Wyoming--A summary, compiled and edited by T.D. Steele and D.E. Hillier. 1981.

C 900. Guide to obtaining USGS information, compiled by Kurt Dodd, H.K. Fuller, and P.F.Clark (revised). 1989.

C 1001. Estimated use of water in the United States in 1980, by W.B. Solley, E.B. Chase, and W.B. Mann, IV. 1983.

C 1004. Estimated use of water in the United States in 1985, by W.B. Solley, C.F. Merk, and R.R. Price. 1988.

\section{Water-Resources Investigations Reports (WRIR)}

Reports in this series are available for inspection at the Wyoming and Reston, Virginia, offices of the USGS. Selected reports may be purchased either as microfilm or paper copy from the National Technical Information Service (NTIS), U.S. Department of Commerce, Springfield, VA 22161; the NTIS ordering number is given in parentheses at the end of the citation. Further information about these reports may be obtained from the District Chief, Water Resources Division, Cheyenne. 
WRIR 3-75. Hydrologic analysis of the valley-fill aquifer, North Platte River valley, Goshen County, Wyoming, by M.A. Crist. 1975. (PB-243 226/AS).

WRIR 63-75. Preliminary digital model of ground-water flow in the Madison Group, Powder River basin and adjacent areas, Wyoming, Montana, South Dakota, North Dakota, and Nebraska, by L.F. Konikow. 1976.

WRIR 8-76. Digital model to predict effects of pumping from the Arikaree aquifer in the Dwyer area, southeastern Wyoming, by G.C. Lines. 1976.

WRIR 76-77. Hydrologic effects of hypothetical earthquake-caused floods below Jackson Lake, northwestern Wyoming, by W.R. Glass, T.N. Keefer, and J.G. Rank 1. 1976.

WRIR 76-112. Techniques for estimating flow characteristics of Wyoming streams, by H.W. Lowham. 1976. (PB-264 224/AS)

WRIR 76-118. Geohydrology of the Albin and LaGrange areas, southeastern Wyoming, by W.B. Borchert. 1976.

WRIR 77-72. Physical, chemical, and biological relations of four ponds in the Hidden Creek strip-mine area, Powder River basin, Wyoming, by D.J. Wangsness. 1977. (PB-273 512/AS)

WRIR 77-103. An analysis of salinity in streams of the Green River basin, Wyoming, by L.L. DeLong. 1977. (PB-275 728/AS)

WRIR 77-107. Preliminary model of the Arikaree aquifer in the Sweetwater River basin, central Wyoming, by W.B. Borchert. 1977.

WRIR 77-111. Hydrologic evaluation of the Arikaree Formation near Lusk, Niobrara and Goshen Counties, Wyoming, by M.A. Crist. 1977.

WRIR 78-13. An analysis of stream temperatures, Green River basin, Wyoming, by H.W. Lowham. 1978. (PB-284 062/AS)

WRIR 78-96. Preliminary applications of Landsat images and aerial photography for determining land-use, geologic, and hydrologic characteristics--Yampa River basin, Colorado and Wyoming, by F.J. Heimes, G.K. Moore, and T.D. Steele. 1978.

WRIR 78-121. The biology of Salt Wells Creek and its tributaries, southwestern Wyoming, by M.J. Engelke, Jr. 1978. (PB-300 828/AS)

WRIR 78-122. Traveltime, unit-concentration, longitudinal-dispersion, and reaeration characteristics of upstream reaches of the Yampa and Little Snake Rivers, Colorado and Wyoming, by D.P. Bauer, R.E. Rathbun, and H.W. Lowham. 1979. (PB-80 129 521/AS)

WRIR 79-6. Hydrogeologic features of the alluvial deposits in the Greybull River valley, Bighorn basin, Wyoming, by M.E. Cooley and W.J. Head. 1979. 
WRIR 79-47. Effect on sediment yield and water quality of a nonrehabilitated surface mine in north-central Wyoming, by B.H. Ringen, L.M. Shown, R.F. Hadley, and T.K. Hinkley. 1979. (PB-299 868/AS)

WRIR 79-1291. Hydrogeologic features of the alluvial deposits in the Nowood River drainage area, Bighorn basin, Wyoming, by M.E. Cooley and W.J. Head. 1979.

WRIR 80-8. Analysis of stream quality in the Yampa River basin, Colorado and Wyoming, by D.A. Wentz and T.D. Steele. 1980. (PB-81 108 904/AS)

WRIR 80-50. Kriging analysis of mean annual precipitation, Powder River basin, Montana and Wyoming, by M.R. Karlinger and J.A. Skrivan. 1980. (PB-81 216 806/AS)

WRIR 80-85. Water resources of upper Separation Creek basin, south-central Wyoming, by L.R. Larson and E.A. Zimmerman. 1981. (PB-81 224 263/AS)

WRIR 80-111. Evaluating methods for determining water use in the High Plains in parts of Colorado, Kansas, Nebraska, New Mexico, Oklahoma, South Dakota, Texas, and Wyoming, by F.J. Heimes and R.R. Luckey. 1980. (PB-81 205 270/AS)

WRIR 80-729. Preliminary map showing freshwater heads for the Mission Canyon and Lodgepole Limestones and equivalent rocks of Mississippian age in the Northern Great Plains of Montana, North and South Dakota, and Wyoming, by R.W. Miller and S.A. Strausz. 1980.

WRIR 80-730. Preliminary map showing freshwater heads for the Red River Formation, Bighorn Dolomite, and equivalent rocks of Ordovician age in the Northern Great Plains of Montana, North and South Dakota, and Wyoming, by W.R. Miller and S.A. Strausz. 1980.

WRIR 80-1104. Effects of pumpage on ground-water levels as modeled in Laramie County, Wyoming, by M.A. Crist. 1980.

WRIR 81-62. Hydrology of Salt Wells Creek--A plains stream in southwestern Wyoming, by H.W. Lowham, L.L. DeLong, K.R. Collier, and E.A. Zimmerman. 1982. (PB-82 $201211 / \mathrm{AS})$

WRIR 81-71. Streamflows and channels of the Green River basin, Wyoming, by H.W. Lowham. 1982. (PB-82 207 416/AS)

WRIR 81-72. Sediment transport and source areas of sediment and runoff, Big Sandy River basin, Wyoming, by J.E. Kircher. 1982. (PB-82 215 898/AS)

WRIR 81-75. Methodology for hydrologic evaluation of a potential surface mine: the Red Rim site, Carbon and Sweetwater Counties, Wyoming, by D.G. Frickel, L.M. Shown, R.F. Hadley, and R.F. Miller. 1981.

WRIR 81-76. An empirical method for determining average soil infiltration rates and runoff, Powder River structural basin, Wyoming, by J.G. Rankl. 1982. (PB-82 201 732/AS) 
WRIR 81-692. Base flow and chemical quality of streams in the Northern Great Plains area, Montana and Wyoming, 1977-78, by S.A. Druse, K.A. Dodge, and W.R. Hotchkiss. 1981.

WRIR 82-40. Method for estimating historical irrigation requirements from ground water in the high plains in parts of Colorado, Kansas, Nebraska, New Mexico, Oklahoma, South Dakota, Texas, and Wyoming, by F.J. Heimes and R.R. Luckey. 1982. (PB-82 245 796/AS)

The following eight WRIR reports are part of a series of reports that broadly characterize the hydrology of selected drainage basins within coal provinces, nationwide. Basins in Wyoming are indicated in parentheses. The reports contain numerous maps, graphs, and other illustrations, most of which are reproduced in color. Free copies of the reports for areas 50,51, and 52 are available from District Chief, USGS, 2617 E. Lincolnway, Suite B, Cheyenne, WY 82001.

WRIR 82-682. Hydrology of Area 49, Northern Great Plains and Rocky Mountain Coal Provinces, Montana and Wyoming, by S.E. Slagle and others. 1983. (Tongue River basin)

WRIR 83-146. Hydrology of Area 54, Northern Great Plains and Rocky Mountain Coal Provinces, Colorado and Wyoming, by Gerhard Huhn, P.B. Daddow, G.S. Craig, Jr., and others. 1983 [1984]. (upper North Platte River basin)

WRIR 83-545. Hydrology of Area 50, Northern Great Plains and Rocky Mountain Coal Provinces, Wyoming and Montana, by M.E. Lowry, J.F. Wilson, Jr., and others. 1986 [1987]. (Powder River basin and adjacent areas)

WRIR 83-761. Hydrology of Area 52, Northern Great Plains and Rocky Mountain Coal Provinces, Wyoming, Colorado, Idaho, and Utah, by H.W. Lowham and others. 1985 [1987]. (Green River basin)

WRIR 83-765. Hydrology of Area 53, Northern Great Plains and Rocky Mountain Coal Provinces, Colorado, Utah, and Wyoming, by N.E. Driver and others. 1984 [1987]. (Little Snake River basin)

WRIR 84-141. Hydrology of Area 48, Northern Great Plains and Rocky Mountain Coal Provinces, Montana and Wyoming, by S.E. Slagle and others. 1986. (Clarks Fork River basin)

WRIR 84-734. Hydrology of Area 51, Northern Great Plains and Rocky Mountain Coal Provinces, Wyoming and Montana, by D.A. Peterson and others. 1987. (part of Wind/Bighorn River basin)

WRIR 85-153. Hydrology of Area 59, Northern Great Plains and Rocky Mountain Coal Provinces, Colorado and Wyoming, by N.G. Gaggiani and others. 1986. (South Platte River basin)

The following WRIR reports may be purchased from USGS, Books and OpenFile Reports Section, Box 25425, Federal Center, Denver, CO 80225. A report listed as "In press" is not yet available. 
WRIR 82-4003. Evaluation of selected surface-water-quality stations in Wyoming, by S.J. Rucker, IV and L.L. DeLong. 1987.

WRIR 82-4007. Hydrologic features of the alluvial deposits in the OWl Creek valley, Bighorn basin, Wyoming, by M.E. Cooley and W.J. Head. 1982.

WRIR 82-4008. Water quality of streams and springs, Green River bas in in Wyoming, by L.L. DeLong. 1986.

WRIR 82-4068. Digital model of the Bates Creek alluvial aquifer near Casper, Wyoming, by K.C. Glover. 1983.

WRIR 82-4072. A data-management system for areal interpretive data for the High Plains in parts of Colorado, Kansas, Nebraska, New Mexico, Oklahoma, South Dakota, Texas, and Wyoming, by R.R. Luckey and C.F. Ferrigno. 1982.

WRIR 82-4103. Time of travel and dispersion of solutes in a 36.4-mile reach of the North Platte River downstream from Casper, Wyoming, by

G.W. Armentrout, Jr. and L.R. Larson. 1984.

WRIR 82-4105. Evapotranspiration rates of selected sites in alluvial valleys in the Powder River basin, Wyoming and Montana, by L.W. Lenfest, Jr. 1986 [1988].

WRIR 82-4107. Machine-readable data files from the Madison Limestone and Northern Great Plains Regional Aquifer-System Analysis projects, Montana, Nebraska, North Dakota, South Dakota, and Wyoming, by J.S. Downey. 1982.

WRIR 82-4117. Hydrology of the White Tail Butte area, northern Campbell County, Wyoming, by M.E. Lowry and J.G. Rankl. 1987.

WRIR 83-4024. The ground-water system in the LaGrange aquifer near LaGrange, southeastern Wyoming, by W.B. Borchert. 1985.

WRIR 83-4047. Hydrologic conditions in the Wheatland Flats area, Platte County, Wyoming, by M.A. Crist. 1983.

WRIR 83-4078. Storage analysis for ephemeral streams in semiarid regions, by K.C. Glover. 1984.

WRIR 83-4093. Major geochemical processes related to the hydrology of the Madison aquifer system and associated rocks in parts of Montana, South Dakota, and Wyoming, by J.F. Busby, R.W. Lee, and B.B. Hanshaw. 1983.

WRIR 83-4127. Pesticide data for Wyoming streams, by D.L. Butler. 1987.

WRIR 83-4137. Computer program and data listing for two-dimensional groundwater model for Laramie County, Wyoming, by Marvin A. Crist. 1983.

WRIR 83-4150. Hydrologic evaluation of proposed ground-water withdrawals in Muleshoe Flat near Wheatland, southeastern Wyoming, by Dwight T. Hoxie. 1983. 
WRIR 83-4235. An assessment of cumulative impacts of mining on the hydrology of part of the Powder River structural basin, Wyoming--Progress report, by P.R. Jordon, R.M. Bloyd, and P.B. Daddow. 1984.

WRIR 84-4026. Relationship of suspended sediment to streamflow in the Green River basin, Wyoming, by B.H. Ringen. 1984 .

WRIR 84-4033. Generalized potentiometric-surface map of the High Plains aquifer in Wyoming, 1981, by C.F. Avery and R.A. Pettijohn. 1984.

WRIR 84-4034. Ground-water quality in Wyoming, by L.R. Larson. 1984.

WRIR 84-4040. Ground-water levels and use of water for irrigation in the Saratoga valley, south-central Wyoming, 1980-81, by L.W. Lenfest, Jr. 1986.

WRIR 84-4079. Water resources of Weston County, Wyoming, by M.E. Lowry, W.J. Head, J.G. Rank1, and J.F. Busby. 1986.

WRIR 84-4092. Statistical summary of the chemical quality of surface water in the Powder River coal basin, Hanna coal field, and the Green River coal region, Wyoming, by D.A. Peterson. 1988.

WRIR 84-4172. Water quality of the North Platte River, east-central Wyoming, by L.R. Larson. 1985.

WRIR 84-4356. Wastewater movement near four treatment and disposal sites in Yellowstone National Park, Wyoming, by E.R. Cox. 1986.

WRIR 85-4091. Divisions of potential fracture permeability, based on distribution of structures and lineaments, in sedimentary rocks of the Rocky Mountains--High Plains region, Western United States, by M.E. Cooley. 1986.

WRIR 85-4154. Altitude and configuration of the water table, and depth to water near Cheyenne, Wyoming, May 1984, by M.A. Crist. 1985.

WRIR 85-4229. Ground-water flow systems in the Powder River structural basin, Wyoming and Montana, by J.G. Rankl and M.E. Lowry. 1990.

WRIR 85-4246. An assessment of low flows in streams in northwestern Wyoming, by G.W. Armentrout, Jr. and J.F. Wilson, Jr. 1987.

WRIR 85-4281. Hydrogeology and simulation of water flow in strata above the Bearpaw Shale and equivalents of eastern Montana and northeastern Wyoming, by W.R. Hotchkiss and J.F. Levings. 1986.

WRIR 85-4287. Invertebrate communities of small streams in northeastern Wyoming, by D.A. Peterson. 1990.

WRIR 85-4305. Potentiometric-surface map of the Wyodak-Anderson coal bed, Powder River structural basin, Wyoming, 1973-84, by P.B. Daddow. 1986. 
WRIR 85-4311. Recharge of shallow aquifers through ephemeral stream channels in Wyoming, 1982-83, by L.W. Lenfest, Jr. 1987.

WRIR 85-4314. Analysis of sediment production from two small ephemeral streams in Wyoming, by J.G. Rank1. 1987.

WRIR 86-4016. Water quality of Fremont Lake and New Fork Lakes, western Wyoming--A progress report, by D.A. Peterson, R.C. Averett, and K.L. Mora. 1987.

WRIR 86-4047. A dual-porosity model for simulating solute transport in 011 shale, by K.C. Glover. 1987.

WRIR 86-4063. Machine-readable files for the High Plains Regional AquiferSystem Analysis in parts of Colorado, Kansas, Nebraska, New Mexico, Oklahoma, South Dakota, Texas, and Wyoming, by C.F. Ferrigno. 1986.

WRIR 86-4170. Selected hydrologic and physical properties of the Mesozoic formations in the upper Colorado River basin in Arizona, Colorado, Utah, and Wyoming--excluding the San Juan basin, by J.F. Weigel. 1987.

WRIR 86-4205. Water-table contours and depth to water in the southeastern part of the Sweetwater River basin, central Wyoming, by W.B. Borchert. 1987.

WRIR 86-4319. A finite-element model for simulating hydraulic interchange of surface and ground water, by K.C. Glover. 1988.

WRIR 86-4329. Investigations of possible effects of surface coal mining on hydrology and landscape stability in part of the Powder River structural basin, northeastern Wyoming, by R.M. Bloyd, P.B. Daddow, P.R. Jordon, K.C. Glover, and others. 1986.

WRIR 87-4018. Streamflow characteristics of the Missouri River basin, Wyoming, through 1984 , by D.A. Peterson. 1988.

WRIR 87-4022. Streamflow characteristics of the Green, Bear, and Snake River basins, Wyoming, through 1984 , by D.A. Peterson. 1988.

WRIR 87-4102. Geohydrology and potential effects of coal mining in 12 coallease areas, Powder River structural basin, northeastern Wyoming, by J.L. Fogg, M.W. Martin, and P.B. Daddow. 1991.

WRIR 87-4138. Regional Aquifer-System Analysis Program of the USGS-Bibliography, 1978-86, by J.B. Weeks and R.J. Sun. 1987.

WRIR 87-4200. Geochemistry of batch-extract waters derived from spoil material collected at the Cordero coal mine, Powder River basin, Wyoming, by D.L. Naftz. 1990 .

WRIR 87-4222. Estimating average dissolved-50lids yields from basins drained by ephemeral and intermittent streams--Green River basin, Wyoming, by L.L. DeLong and D.K. Wells. 1988. 
WRIR 87-4225. Precipitation records and flood-producing storms in Cheyenne, Wyoming, by J.B. Lindner-Lunsford. 1988.

WRIR 87-4255. Reconnaissance investigation of water quality, bottom sediment, and biota associated with irrigation drainage in the Kendrick Reclamation Project area, Wyoming, 1986-87, by D.A. Peterson, W.E. Jones, and A.G. Morton. 1988.

WRIR 87-4264. Cost-effectiveness of the streamflow-gaging program in Wyoming, by S.A. Druse and K.L. Wahl. 1988.

WRIR 88-4021. Fremont Lake, Wyoming--Some aspects of the inflow of water and sediment, by W.W. Emmett and R.C. Averett. 1989.

WRIR 88-4045. Streamflows in Wyoming, by H.W. Lowham. 1988.

WRIR 88-4046. Cumulative potential hydrologic impacts of surface coal mining in the eastern Powder River structural basin, northeastern Wyoming, by L.J. Martin, D.L. Naftz, H.W. Lowham, and J.G. Rank1. 1989.

WRIR 88-4064. Flood boundaries and water-surface profile for the computed 100-year flood, Swift Creek at Afton, Wyoming, 1986, by J.G. Rankl and J.C. Wallace. 1989.

WRIR 88-4192. Streamflow recharge to the Madison Limestone and the Casper Formation in the Glenrock area, east-central Wyoming, by D.A. Peterson. In press.

WRIR 88-4196. Evaluation of ground-water-level changes near Gillette, northeastern Wyoming, by M.A. Crist. In press.

WRIR 88-4209. Use of paleoflood investigations to improve flood-frequency analyses of plains streams in Wyoming, by M.E. Cooley. 1990.

WRIR 88-4215. Procedure for evaluating observation-well networks in Wyoming, and application to northeastern Wyoming, 1986, by J.C. Wallace and M.A. Crist. 1989.

WRIR 89-4002. Hydrology of the Powder River alluvium between Sussex, Wyoming, and Moorhead, Montana, by B.H. Ringen and P.B. Daddow. 1990.

WRIR 89-4078. A concept of the shallow ground-water system along the North Platte River, south-central Wyoming, by M.A. Crist. 1990.

WRIR 89-4173. Stream-aquifer system in the upper Bear River valley, Wyoming, by K.C. Glover. 1990.

WRIR 90-4154. Assessment of the hydrologic system and hydrologic effects of uranium exploration and mining in the southern Powder River basin uranium district and adjacent areas, Wyoming, by M.L. Lowry, P.B. Daddow, and S.J. Rucker, IV. In press. 
WRIR 90-4186. Use of geographic information system for estimating traveltimes of boats through bald eagle habitat along the Snake River, northwestern Wyoming, by J.F. Wilson, Jr., and C.A. Esheiman. In press.

WRIR 90-4187. Reconnaissance investigation of water quality, bottom sediment, and biota associated with irrigation drainage in the Riverton Reclamation Project, Wyoming, 1988-89, by D.A. Peterson, T.F. Harms, Pedro Ramirez, Jr., G.T. Allen, and A.H. Christenson. 1991.

WRIR 91-4000. Selenium and associated trace-element concentrations in soil, rock, water, and streambed sediment, Sandstone Reservoir Project, southcentral Wyoming, by D.L. Naftz and C.S.V. Barclay. In press.

WRIR 91-4029. Trends in selected water-quality characteristics, Powder River and tributaries, Montana and Wyoming, water years 1968-88 and 1975-88, by L.E. Cary. In press.

WRIR 91-4044. Water resources of Washakie County, Wyoming, by D.D. Susong, M.L. Smalley, and E.R. Banta. In press.

WRIR 91-4067. Shallow ground water in the Powder River basin, northeastern Wyoming--Description of selected publications, 1950-91, and indications for further study, by J.B. Lindner-Lunsford and J.F. Wilson, Jr. In press.

\section{Water-Data Reports}

The following water-data reports may be purchased as paper copy or microfiche only from the National Technical Information Service (NTIS), U.S. Department of Commerce, Springfield, VA 22161. They are available for inspection only at the Wyoming and Reston, VA, offices of the USGS. The PB number in parentheses is the NTIS ordering number.

Water resources data for Wyoming--Water year 1971, part 1, surface-water records. 1972. (PB-289 523/AS)

Water resources data for Wyoming--Water year 1971, part 2, water-quality records. 1972. (PB-289 524/AS)

Water resources data for Wyoming--Water year 1972, part 1, surface-water records. 1973. (PB-289 525/AS)

Water resources data for Wyoming--Water year 1972, part 2, water-quality records. 1973. (PB-289 526/AS)

Water resources data for Wyoming--Water year 1973, part 1, surface-water records. 1974. (PB-289 527/AS)

Water resources data for Wyoming--Water year 1973, part 2, water-quality records. 1974. (PB-289 528/AS) 
Water resources data for Wyoming--Water year 1974, part 1, surface-water records. 1975. (PB-289 529/AS)

Water resources data for Wyoming--Water year 1974, part 2, water-quality records. 1975. (PB-289 530/AS)

WY-75-1. Water resources data for Wyoming--Water year 1975. 1976. (PB-259 841/AS)

WY-76-1. Water resources data for Wyoming--Water year 1976, volume 1, Missouri River basin. 1977. (PB-278 818/AS)

WY-76-2. Water resources data for Wyoming--Water year 1976, volume 2, Green River basin, Bear River basin, and Snake River basin. 1977. (PB-285 744/AS)

WY-77-1. Water resources data for Wyoming--Water year 1977, volume 1, Missouri River basin. 1978. (PB-293 493/AS)

WY-77-2. Water resources data for Wyoming--Water year 1977, volume 2, Green River basin, Bear River basin, and Snake River basin. 1978. (PB-293 494/AS)

WY-78-1. Water resources data for Wyoming--Water year 1978, volume 1, Missouri River basin. 1979. (PB-80 165 152/AS)

WY-78-2. Water resources data for Wyoming--Water year 1978, volume 2, Green River basin, Bear River basin, and Snake River basin. 1979. (PB-80 177 587/AS)

WY-79-1. Water resources data for Wyoming--Water year 1979, volume 1, Missouri River basin. 1980. (PB-81 103 129/AS)

WY-79-2. Water resources data for Wyoming--Water year 1979, volume 2, Green River basin, Bear River basin, and Snake River basin. 1980. (PB-80 $212 \quad 137 / \mathrm{AS})$

WY-80-1. Water resources data for Wyoming--Water year 1980, volume 1, Missouri River basin. 1981. (PB-82 153 024/AS)

WY-80-2. Water resources data for Wyoming--Water year 1980, volume 2, Green River basin, Bear River basin, and Snake River basin. 1981. (PB-82 154 337/AS)

WY-81-1. Water resources data, Wyoming--Water year 1981, volume 1, Missouri River basin. 1982. (PB-83 170 944/AS)

WY-81-2. Water resources data, Wyoming--Water year 1981, volume 2, Green River basin, Bear River basin, and Snake River basin. 1982. (PB-83 170 951/AS)

WY-82-1. Water resources data, Wyoming--Water year 1982. 1983. (PB-84 114 669/AS) 
WY-83-1. Water resources data, Wyoming--Water year 1983. 1984. (PB-85 127 371/AS)

WY-84-1. Water resources data, Wyoming--Water year 1984. 1985. (PB-86 106 127/AS)

WY-85-1. Water resources data, Wyoming--Water year 1985. 1986. (PB-87 172 565/AS)

WY-86-1. Water resources data, Wyoming--Water year 1986. 1987. (PB-87 231 056/AS)

WY-87-1. Water resources data, Wyoming--Water year 1987. 1988. (PB-88 240 338/AS)

WY-88-1. Water resources data, Wyoming--Water year 1988. 1989. (PB-89 194 955/AS)

WY-89-1. Water resources data, Wyoming--Water year 1989. 1990. (PB-90 220 252/AS)

WY-90-1. Water resources data, Wyoming--Water year 1990. 1991. (PB-91 190 942/AS)

\section{Hydrologic Investigations Atlases (HA)}

Hydrologic Investigations Atlases are sold by U.S. Geological Survey, Map Distribution, Federal Center, Building 810, Box 25286, Denver, C0 80225.

HA-219. Ground-water reconnaissance of the Great Divide and Washakie basins and some adjacent areas, southwestern Wyoming, by G.E. Welder and L.J. McGreevy. 1966.

HA-270. Ground-water resources and geology of the Wind River basin area, central Wyoming, by H.A. Whitcomb and M.E. Lowry. 1968.

HA-290. Ground-water reconnaissance of the Green River basin, southwestern Wyoming, by G.E. Welder. 1968.

HA-417. Quality of surface-water in the Bear River basin, Utah, Wyoming, and Idaho, by K.M. Wadde 11 and Don Price. 1972.

HA-465. Water resources of the Powder River basin and adjacent areas, northeastern Wyoming, by W.G. Hodson, R.H. Pearl, and S.A. Druse. 1973.

HA-471. Water resources of the Laramie, Shirley and Hanna basins and adjacent areas, southeastern Wyoming, by M.E. Lowry, S.J. Rucker IV, and K.L. Wah1. 1973.

HA-477. Selected hydrologic data in the Upper Colorado River basin, by Don Price and K.M. Waddell. 1974.

HA-487. Water in the Great Basin region; Idaho, Nevada, Utah, and Wyoming, by Don Price, T.E. Eakin, and others. 1974. 
HA-512. Water resources of the Bighorn basin, northwestern Wyoming, by

M.E. Lowry, H.W. Lowham, and G.C. Lines. 1976.

HA-539. Water resources of the thrust belt of western Wyoming, by G.C. Lines and W.R. Glass. 1975.

HA-558. Water resources of northwestern Wyoming, by E.R. Cox. 1976.

HA-642. Water table in the High Plains Aquifer in 1978 in parts of Colorado, Kansas, Nebraska, New Mexico, Oklahoma, South Dakota, Texas, and Wyoming, by E.D. Gutentag and J.B. Weeks. 1980.

HA-648. Bedrock geology, altitude of base, and 1980 saturated thickness of High Plains Aquifer in parts of Colorado, Kansas, Nebraska, New Mexico, Oklahoma, South Dakota, Texas, and Wyoming, by J.B. Weeks and E.D. Gutentag. 1981.

HA-652. Water-level and saturated thickness changes, predevelopment to 1980 in the High Plains Aquifer in parts of Colorado, Kansas, Nebraska, New Mexico, South Dakota, Texas, and Wyoming, by R.R. Luckey, E.D. Gutentag, and J.B. Weeks. 1981.

HA-658. Dissolved solids and sodium in water from the High Plains Aquifer in parts of Colorado, Kansas, Nebraska, New Mexico, Oklahoma, South Dakota, Texas, and Wyoming, by N.C. Krothe, J.W. Oliver, and J.B. Weeks. 1982.

HA-687. Hydrogeologic framework of the Upper Colorado River basin--excluding the San Juan basin--Colorado, Utah, Wyoming, and Arizona, by 0.J. Taylor, J.W. Hood, and E.A. Zimmerman. 1986.

HA-698. General hydrogeology of the aquifers of Mesozoic age, Upper Colorado River basin; excluding the San Juan Basin; Colorado, Utah, Wyoming, and Arizona, by G.W. Freethey, B.A. Kimball, D.E. Wilberg, and J.W. Hood. 1988.

HA-699. Flood of August 1, 1985, in Cheyenne, Wyoming, by S.A. Druse, M.E. Cooley, S.L. Green, and H.W. Lowham. 1986.

HA-702. Hydrogeology of aquifers of Paleozoic age, upper Colorado River basin--excluding the San Juan Basin--in Colorado, Utah, Wyoming, and Arizona, by J.B. Lindner-Lunsford, B.A. Kimball, D.T. Chafin, and C.G. Bryant. 1989.

\section{Hydrologic Unit Maps}

Hydrologic Unit Maps are sold by U.S. Geological Survey, Map Distribution, Federal Center, Building 810, Box 25286, Denver, CO 80225.

Hydrologic unit map of Wyoming--1974, by U.S. Geological Survey. 1976. 


\section{Miscellaneous Investigations Maps (I)}

Miscellaneous Investigations Maps are sold by U.S. Geological Survey, Map Distribution, Federal Center, Building 810, Box 25286, Denver, CO 80225.

I-847-A. Energy resources map of the Powder River basin, Wyoming and Montana, by W.R. Keefer and T.W. Schmidt. 1973.

I-847-B. Map showing streamflow volumes in northeastern wyoming and southeastern Montana, by D.G. Frickel and L.M. Shown. 1974.

I-847-C. Maps showing configuration and thickness, and potentiometric surface and water quality in the Madison Group, Powder River basin, Wyoming and Montana, by F.A. Swenson, W.R. Miller, W.G. Hodson, and F.N. Visher. 1976.

I-848-A. Land use map of the Gillette area, Wyoming, 1970, by L.M. Shown. 1973.

I-848-E. Maps showing occurrence of ground water in the Gillette area, Campbell County, Wyoming, by N.J. King. 1974 .

I-848-F. Map showing some potential effects of surface mining of the WyodakAnderson coal, Gillette area, Campbell County, Wyoming, by R.F. Hadley and W.R. Keefer. 1975.

I-1159. Maps showing formation temperatures and configurations of the tops of the Minnelusa Formation and the Madison Limestone, Powder River basin, Wyoming, Montana, and adjacent areas, by W.J. Head, K.T. Kilty, and R.K. Knottek. 1979.

I-1308. Generalized fence diagram showing stratigraphy and potentiometric surface of the Tertiary formations in southeastern Wyoming and an adjacent part of Colorado, by M.E. Cooley and M.A. Crist. 1981.

I-1317. Thickness, percent sand, and configuration of shallow hydrogeologic units in the Powder River basin, Montana and Wyoming, by B.D. Lewis and W.R. Hotchkiss. 1981.

I-1687. Divisions of potential fracture permeability based on distribution of structures and linear features in sedimentary rocks, Northern Great Plains--Rocky Mountain region of Montana, North Dakota, South Dakota, Wyoming, and northern Nebraska, by M.E. Cooley. 1986.

\section{Open-File Reports and Maps}

Open-file reports, which may be in manuscript form, generally are not reproduced and distributed in quantity. These reports are available for inspection in the Cheyenne, WY, and Reston, VA, of fices of the USGS. Most numbered open-file reports may be purchased from U.S. Geological Survey, Books and Open-File Reports Section, Box 25425, Federal Center, Denver, C0 80225. Information on 
the availability of numbered and unnumbered reports may be obtained from the District Chief, Cheyenne, Wyoming; free copies of some reports, such as periodic compilations of ground-water levels, are available from the Cheyenne office.

\section{Numbered Open-File Reports}

75-614. Geohydrologic reconnaissance and measurement of perennial streams crossing outcrops of the Madison Limestone, northeastern Wyoming, 1974, by F.C. Boner, M.E. Lowry, G.C. Lines, and J.E. Powell. 1976.

76-22. Data for calibrating unsteady-flow sediment-transport models, East Fork River, Wyoming, 1975, by H.A. Mahoney, E.D. Andrews, W.W. Emmett, L.B. Leopold, R.H. Meade, R.M. Myrick, and C.F. Nordin, Jr. 1976.

76-237. Floodflow characteristics at bridge site on Interstate 80 , the Green River near Green River, Wyoming, by G.S. Craig, Jr. 1976.

76-598. Ground-water levels in Wyoming, 1975, by W.C. Ballance and P.B. Freudenthal. 1976.

77-164. Report on preliminary data for Madison Limestone test well No. 1, NE1/4SE1/4 sec.15, T. 57 N., R. 65 W., Crook County, Wyoming, by R.K. Blankennagel, W.R. Miller, D.L. Brown, and E.M. Cushing. 1977.

77-275. Preliminary evaluation of waste-water movement in and near Grand Teton National Park, Wyoming, through October 1976, by E.R. Cox. 1977.

77-676. Digital model of the Arikaree aquifer near Wheatland, southeastern Wyoming, by D.T. Hoxie. 1977.

77-686. Ground-water levels in Wyoming, 1976, by W.C. Ballance and P.B. Freudenthal. 1977.

77-872. Geochemistry of ground waters in the Powder River coal region, by G.L. Feder, Roger Lee, J.F. Busby, and L.G. Saindon, in Geochemical survey of the western energy regions, Fourth annual progress report. 1977.

78-605. Ground-water levels in Wyoming, 1977, by M.D. Stevens. 1978.

78-884. A computer program for simulating salinity loads in streams, by K.C. Glover. 1978.

78-985. Data for floods of May 1978 in northeastern Wyoming and southeastern Montana, by Charles Parrett, D.D. Carlson, G.S. Craig, Jr., and D.A. Hull. 1978.

79-1277. Water-quality data for the Hanna and Carbon basins, Wyoming, by P.B. Freudenthal. 1979.

79-1278. Water-resources investigations of the U.S. Geological Survey in Wyoming, fiscal year 1979, by D.D. Carlson and S.L. Green. 1979. 
79-1280. Results of transient simulations of a digital model of the Arikaree aquifer near Wheatland, southeastern Wyoming, by D.T. Hoxie. 1979.

80-15. Projected effects of intermittent changes in withdrawal of water from the Arikaree aquifer near Wheatland, southeastern Wyoming, by D.T. Hoxie. 1980 .

80-748. Maps showing the dissolved solids concentration of waters in the Red River Formation and Mission Canyon Limestone in North Dakota, South Dakota, and parts of Wyoming and Montana, by Sheila Stenzel, Rebecca Buss, and John Busby. 1980.

80-1101. Behavioral and catastrophic drift of invertebrates in two streams in northeastern Wyoming, by D.J. Wangsness and D.A. Peterson. 1980 .

80-1110. Effects of herbicide usage on water quality of selected streams in Wyoming, by D.L. Butler. 1980 .

80-1189. Field data describing the movement and storage of sediment in the East Fork River, Wyoming. Part I, River hydraulics and sediment transport, 1979, by W.W. Emmett, R.M. Myrick, and R.H. Meade. 1980.

80-1190. Field data describing the movement and storage of sediment in the East Fork River, Wyoming. Part II, Bed elevations, 1979, by R.H. Meade, R.M. Myrick, and W.W. Ermett. 1980.

81-201. Water-resources investigations of the U.S. Geological Survey in Wyoming, fiscal year 1980 , by S.L. Green. 1981 .

81-410. Hydrologic data for the Cache Creek-Bear Thrust Environmental Impact Statement near Jackson, Wyoming, by G.S. Craig, Jr., B.H. Ringen, and E.R. Cox. 1981 .

81-422. Water-level contours near LaGrange, southeastern Wyoming and an adjacent part of Nebraska, April 30, 1980, by W.B. Borchert. 1981.

82-0359. Field data describing the movement and storage of sediment in the East Fork River, Wyoming: Part III, River hydraulics and sediment transport, 1980, by W.W. Emmett, R.M. Myrick, and R.H. Meade. 1982.

82-0360. Field data describing the movement and storage of sediment in the East Fork River, Wyoming: Part IV, Bed elevation, 1980, by R.H. Meade, R.M. Myrick, and W.W. Emmett. 1982.

82-446. Preliminary data for Northern Great Plains test well 1 , NW1/4NE1/4 sec.11, T. 55 N., R. 77 W., Sheridan County, Wyoming, by D.H. Lobmeyer, L.0. Anna, and J.F. Busby. 1982.

82-856. Ground-water data from selected wells in alluvial aquifers, Powder River basin, northeastern Wyoming, by D.K. Wells. 1982 .

82-859. Ground-water levels in Wyoming, 1971 through part of 1980 , by J.0. Ragsdale. 1982 . 
83-29. Pumpage data from irrigation wells in eastern Laramie County, Wyoming, and Kimball County, Nebraska, by C.F. Avery. 1983.

83-254. Water-resources investigations of the U.S. Geological Survey in Wyoming, fiscal year 1981 and 1982, compiled by S.L. Green. 1983.

83-770. Water-resources investigations of the U.S. Geological Survey in Wyoming, fiscal year 1983, compiled by S.L. Green. 1984.

83-935. Linear features determined from Landsat imagery in Wyoming, map, scale 1:500,000, by M.E. Cooley. 1983 [1984].

83-943. Ground-water data, Green River basin, Wyoming, by E.A. Zimmerman and K.R. Collier. 1985.

83-939. Ground-water quality data from the Powder River basin, northeastern Wyoming, by L.R. Larson and R.L. Daddow. 1984.

84-622. Water-resources investigations of the U.S. Geological Survey in Wyoming, fiscal year 1984, compiled by S.L. Green. 1984.

85-161. Streamflow and suspended-sediment discharge from two small watersheds in southwestern Wyoming and northeastern Utah, 1984, by L.W. Lenfest, Jr. and B.H. Ringen. 1985.

85-169. Field data describing the movement and storage of sediment in the East Fork River, Wyoming; Part V, Bed-material tracers, 1979 and 1980, by W.W. Emmett and R.M. Myrick. 1985.

85-403. Ground-water levels in Wyoming, 1974 through 1983, by J.0. Ragsdale and C.B. Oberender. 1985.

85-486. Hydraulic and sediment transport data, East Fork River, Wyoming, 1978, by W.W. Emmett, R.M. Myrick, and H.A. Martinson. 1985.

85-562. Water-resources activities of the U.S. Geological Survey in Wyoming, fiscal year 1985, compiled by S.L. Green. 1985.

85-628. Ground-water data through 1980 for the Hanna and Carbon basins, south-central Wyoming, by P.B. Daddow. 1986.

85-685. Use and availability of continuous streamflow records in wyoming, by J.R. Schuetz. 1986.

86-69. Discharge and water quality of Horse Creek, southeastern Wyoming, MayNovember, 1985, by J.F. Meyer and L.W. Lenfest, Jr. 1986.

87-456. Ground-water levels in Wyoming, 1976 through 1985, by H.I. Kennedy and C.B. Oberender. 1987.

87-532. Water-resources activities of the U.S. Geological Survey in Wyoming, fiscal years 1986 and 1987, compiled by S.L. Green and J.R. Schuetz. 1987. 
87-559. Preliminary surficial geology map of the Cheyenne urban area, Laramie County, Wyoming, by M.E. Cooley. 1987.

87-763. Wyoming [ground-water quality], by K.L. Mora, L.R. Larson, and S.J. Rucker IV (article in Water-Supply Paper 2325). 1988.

88-121. U.S. Geological Survey ground-water studies in Wyoming, compiled by J.F. Wilson, Jr. and M.L. Maderak (Water Fact Sheet). 1988.

88-187. Ground-water levels in Wyoming, 1978 through September 1987, by H.I. Kennedy and S.L. Green. 1988.

88-481. Coal-spoil and ground-water chemical data for two coal mines; Hanna basin and Powder River basin, Wyoming, by L.R. Larson. 1988.

89-59. Hydrologic data for Paleozoic rocks in the upper Colorado River basin, Colorado, Utah, Wyoming, and Arizona, by A.L. Geldon. 1989.

89-262. Water-resources activities of the U.S. Geological Survey in Wyoming, fiscal years 1988 and 1989 , by D.M. Oden. 1989.

90-106. Ground-water levels in Wyoming, 1980 through September 1989, by H.I. Kennedy and S.L. Green. 1990.

\section{Unnumbered Open-File Reports}

Babcock, H.M., and Keech, C.F., 1957, Estimates of underflow in the Niobrara River basin across the Wyoming-Nebraska State line.

Ballance, W.C., and Freudenthal, P.B., 1975, Ground-water levels in Wyoming, 1974.

Cox, E.R., 1973, Water resources of Yellowstone National Park, Wyoming, Montana, and Idaho.

1973, Remote sensing in a water-resources study of Yellowstone National Park, Wyoming, Montana, and Idaho.

1974, Water resources of Grand Teton National Park, Wyoming.

Crist, M.A., and Borchert, W.B., 1972, The ground-water system in southeastern Laramie County, Wyoming.

Lowham, H.W., 1969, Sediment investigations in Big Sand Coulee basin, Wyoming and Montana.

Lowham, H.W., and Wilson, J.F., Jr., 1971, Preliminary results of time-oftravel measurements on Wind/Bighorn River from Boysen Dam to Greybull, Wyoming.

Lowry, M.E., 1962, Development of ground water in the vicinity of Ten Sleep, Wyoming. 
1973, Hydrology of the uppermost Cretaceous and lowermost Paleocene rocks in the Hilight oil field, Campbell County, Wyoming.

O'Connel1, D.J., 1969, Surface-water discharge and ground-water levels in the East Fork River area, Sublette County, Wyoming.

Rennick, K.B., 1966, Floods of May-June 1965, in east-central Wyoming. Wahl, K.L., 1970, A proposed streamflow data program for Wyoming.

\section{Publications of Wyoming State Agencies}

The following reports were prepared by the USGS in cooperation with various State agencies and were published by the State of Wyoming. Information about the availability of the reports can be obtained from the District Chief, USGS, Water Resources Division, 2617 E. Lincolnway, Suite B, Cheyenne, WY 82001 .

Cox, E.R., 1975, Discharge measurements and chemical analyses of water in northwestern Wyoming: Wyoming State Engineer's Office, Wyoming Water Planning Program Report, no. 14.

Druse, S.A., Lowham, H.W., Cooley, M.E., and Wacker, A.M., 1988, Floodflow characteristics of Wyoming streams--A compilation of previous investigations: Wyoming Highway Department report.

Hodson, W.G., 1971a, Logs of wells in Campbell County: Wyoming State Engineer's Office, Wyoming Water Planning Program Report, no. 8.

$1971 b$, Chemical analyses of ground water in the Powder River basin and adjacent areas, northeastern Wyoming: Wyoming Department of Economic Planning and Development report.

1974, Records of water wells, springs, oil- and gas-test holes, and Chemical analyses of water for the Madison Limestone and equivalent rocks in the Powder River basin and adjacent areas, northeastern Wyoming: Wyoming State Engineer's Office report.

Lowham, H.W., Kircher, J.E., and Boner, F.C., 1975, Temperatures of Wyoming streams: Wyoming State Engineer's Office, Wyoming Water Planning Program Report, no. 15.

Lowry, M.E., and Lines, G.C., 1972, Chemical analyses of ground water in the Bighorn basin, northwestern Wyoming: Wyoming Department of Economic Planning and Development report.

Rank1, J.G., and Barker, D.S., 1977, Rainfall and runoff data from small basins in Wyoming: Wyoming State Engineer's Office, Wyoming Water Planning Program Report, no. 17. 
Rankl, J.G., and Carnevale, M.A., 1989, Traveltime and reaeration coefficients for the North Platte River, Casper to Orin, Wyoming: Wyoming Department of Environmental Quality report.

Ringen, B.H., 1973, Records of ground-water levels in Wyoming, 1940-1971: Wyoming State Engineer's Office, Wyoming Water Planning Program Report, no. 13.

1974, Ground-water levels in Wyoming, 1972-1973: Wyoming State Engineer's Office, Wyoming Water Planning Program Report, no. 13, Supplement no. 1 .

U.S. Geological Survey, 1971, Chemical quality of water in southeastern Wyoming: Wyoming Department of Economic Planning and Development report.

We11s, D.K., Busby, J.F., and Glover, K.C., 1979, Chemical analyses of water from the Minnelusa Formation and equivalents in the Powder River basin and adjacent areas, northeastern Wyoming: Wyoming State Engineer's Office, Wyoming Water Planning Program Report, no. 18.

\section{Other Publications}

Availability of most of the following reports can be determined by contacting the publisher. Separate prints of some of the articles may be obtained from the District Office in Cheyenne.

Andrews, E.D., 1981, Measurement and computation of bed-material discharge in a shallow sand-bed stream, Muddy Creek, Wyoming: Water Resources Research, v. 17, p. 131-141.

Gordon, E.D., King, N.J., Haynes, G.L., Jr., and Cummings, T.R., 1960, occurrence and quality of water in the northern Bridger basin and adjacent overthrust be1t, Wyoming, in Wyoming Geological Association Guidebook, 15th Annual Field Conference, Overthrust belt of southwestern Wyoming and adjacent areas, 1960: p. 227-247.

Lusby, G.C., and Toy, T.J., 1976, An evaluation of surface-mine spoils area rehabilitation in Wyoming using rainfall simulation: Earth Surface Processes, v. 1, p. 375-386.

Naftz, D.L., 1988, Predictive capabilities of batch-mixing experiments using water from a surface coal mine: American Water Resources Association Water Resources Bulletin, v. 24, no. 4, p. 869-877.

Naftz, D.L., and Rice, J.A., 1989, Geochemical processes controlling selenium in ground water after mining, Powder River basin, Wyoming, U.S.A.: Applied Geochemistry, v. 4, no. 6, p. 565-575.

Naftz, D.L., Rice, J.A., and Ranville, J.R., 1991, Glacial-ice composition--A potential long-term record of the chemistry of atmospheric deposition, Wind River Range, Wyoming, U.S.A.: Water Resources Research, v. 27, no. 6 , p. 1231-1238. 
Rankl, J.G., and Smalley, M.L., in press, Transport of sediment by streams in the Sierra Madre, southern Wyoming: American Water Resources Association Water Resources Bulletin.

Wahl, K.L., 1976, Accuracy of channel measurements and the implications in estimating stream flow characteristics, in Modern developments in hydrometry: Padua, Italy, World MeteoroTogical Organization (WMO), no. $427, v .2$, p. 311-319.

1977, Simulation of regional flood frequency curves based on peaks of record, in Conference on Alternative Strategies for Desert Development and Management: United Nations Institute for Training and Research (UNITAR) and California State Department of Water Resources, v. 2, Sacramento, $13 \mathrm{p}$.

Whitcomb, H.A., Morris, D.A., Gordon, E.D., and Robinove, C.J., 1958, Occurrence of ground water in the eastern Powder River basin and western Black Hills, northeastern Wyoming, in Wyoming Geological Association Guidebook, 13th Annual Field Conference, Powder River basin, 1958: p. $245-260$. 